\title{
Palynology and geochemistry of the Frasnian global transgression in the Parnaiba Basin, Brazil
}

\author{
Steemans P. ${ }^{1,}{ }^{*}$, Pereira E. ${ }^{2}$, Le Herisse A. ${ }^{3}$, Grahn Y. ${ }^{4}$, Streel M. ${ }^{1}$, Brito M. ${ }^{2}$, Bergamaschi S. ${ }^{2}$, \\ Rodrigues R. ${ }^{2}$
}

${ }^{1}$ EDDy/Palaeopalynology, Allée du six Août 14, Bât B-18, University of Liège, B-4000 Liège, Belgium

2 Department of Stratigraphy and Paleontology, Universidade do Estado do Rio de Janeiro, Rua São

Francisco Xavier 524, Bloco A, Sala 4030, Maracanã, Rio de Janeiro 20559-900, Brazil

3 University of Brest, UMR 6538 CNRS «Domaines océaniques», IUEM, CS 93837, rue Dumont

D'Urville, 29280 Plouzané, France

${ }^{4}$ Calle Azucena 10, 29680 Estepona, Spain

* Corresponding author : P. Steemans, email address : p.steemans@ulg.ac.be

\begin{abstract}
:
An integrated palynological and geochemical approach has been initiated to date and to precise the geochemical events of the Pimenteiras Formation, in the Late Devonian from the Parnaiba Basin, Brazil. Based on good biostratigraphic markers and presence of index species among miospores, acritarchs and chitinozoa, the investigated sequences are referred to the Middle to early Late Frasnian. Among Miospores, Chelinospora concinna and Verrucosisporites Witt-eras are likely to be from the BPi Interval Zone defined in the Amazon Basin. Chitinozoans of the Early to early Late Frasnian Angochitina (Lagenochitina) avelinoi zone of the Parnaiba Basin are present, and acritarch assemblages arc also consistent with a Middle to early Late Frasnian age, by comparison to assemblages previously described in other Brazilian basins. Some important accompanying species of palynomorphs are illustrated. In the studied outcrops, black shale intervals are referred to top of the Radioactive Sale B and Radioactive Shale C according to Rodrigues (1995) definitions. Top of Radioactive Shale B shows good concentration of terrestrial organic matter, but low potential source of gas. By comparison Radioactive Shale $\mathrm{C}$ of the upper part of the Pimenteiras Formation, with important concentration of marine organic matter have low to high potential as source of gas and condensate. This study shows that a progressive flooding took place during the Devonian period in the Parnaiba Basin with maximum marine transgression in the Frasnian. These global events of interest for hydrocarbon exploration, are regarded as markers for Gondwanan regional chronostratigraphic correlations. (C) 2020 Published by Elsevier B.V.
\end{abstract}

\section{Highlights}

- Miospores, acritarchs and chitinozoans are relatively abundant and well preserved. Palynomorphs provide a concordant age corresponding to the mid-Frasnian. Miospores are correlated with the 
conodont biostratigraphic scale from the Boulonnais. Palynomorphs are characteristic of the Gondwana and more precisely from Brazil. Effective generation of hydrocarbon is dependent of the igneous effect.

Keywords : Miospores, Acritarchs, Chitinozoan, Geochemistry, Frasnian, Brazil 


\section{Introduction}

The Brazilian Palaeozoic basins ¿ $n^{\dagger}$ ^in thick Devonian shaley sections. These sections often display interlaminated m. Astones/siltstones/very fine sandstones deposited in offshore conditions. The chronolorv c $\mathrm{f} \mathrm{T}^{\mathrm{T}}$ alaeozoic sea-level changes suggested by Haq and Schutter (2008) demonstrated $i$ at a new long-term sea-level rise began in the Middle Devonian and reached its ne ${ }^{\prime}$ ' i 1 the early Late Devonian (Frasnian). In the Parnaíba Basin, black-shale intervals W. $^{h}$ Icratively high Total Organic Carbon (TOC) values $(>4.0 \%)$ are frequently detected in the Devonian section. These geochemical signatures are likely related to the Late Devonian worldwide transgression described in the literature (Lüning et al., 2004; Souza et al. 2013, Bond and Wignall, 2008; Trindade and Carvalho, 2018). Therefore, the present work intends to describe the TOC content excursions recorded in the Devonian section of the Parnaíba Basin and date these excursions by means of palynology, to fit the intervals to the global sea-level curve. 
The complementary geochemical data used in this work detailed has made possible for a better understanding of the control of the anoxic / dysoxic conditions of the organic matter preservation, which would typically have taken place within the flooding surfaces associated with the transgression events. In the Devonian section of the Parnaíba Basin, these surfaceswhich show the highest TOC content and the highest Hydrogen Index (HI)—represent the most important hydrocarbon generation intervals.

Rodrigues (1995) identified three potentially generating shale intervals within the Pimenteiras Formation, calling them Radioactive Shales A, B and $\mathcal{C}$ According to Rodrigues (1995), the Radioactive Shale A is positioned approximate' $y$ a the Eifelian / Givetian boundary; has a maximum thickness of $20 \mathrm{~m}$ and exhihits TOC contents ranging from 1.0 to

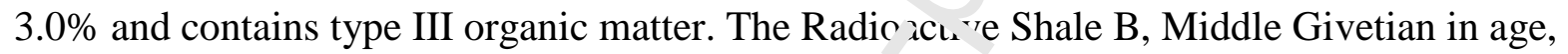
has a maximum thickness of $20 \mathrm{~m}$, TOC conte at car ging from 1.0 to $3.5 \%$ and type II and III organic matter. According to Rodrigues ${ }^{19^{\circ}} j$ ), the Radioactive Shale C, deposited during the Frasnian, is correlatable to the main sou -ce rock intervals in the Solimões (Jandiatuba Formation) and Amazonas (Barreirinh ' 'ormation) basins. It is the main interval of radioactive shale layer in the $b_{n}$ in, 1 eaching a thickness of $40 \mathrm{~m}$. It has TOC contents ranging from between 1.0 and $5.0 \%$ a.d iype II organic matter.

The gas accumu' tluis related to these intervals in the Parnaíba Basin normally display a dry composition. Dry composition is normally indicating a generation at high maturation stage. However, in Parnaíba Basin, this condition is not reached by burial, suggesting an atypical process of generation related to the heat effect of dolerite intrusions (Rodrigues, 1995; Rodrigues et al., 1995, 2012; Zambrano et al., 2017; Miranda et al., 2018; Cioccari and Mizusaki, 2019). 
The palynological samples has revealed a rich assemblage of acritarchs, chitinozoans and miospores. Despite their relative abundance, they all agree with regard to dating the geochemichal events of an equivalent Frasnian age. New observations in Brazil and new data from the Boulonnais Area, Northern France (Streel et al., in press) have made it possible to correlate the Brazilian outcrops with the European conodont zones and therefore with the stratotypes of the Frasnian.

Finally, for the first time, a high precision palynological study has dated the most important source rock intervals of the Parnaíba Basin, the geocheni-al aspects of which have been described in detail. These integrated results are partic $₫ 1 a^{1}{ }^{1} \mathrm{y} 1 \mathrm{mportant}$ and will greatly contribute to more precise future basin modelling studies.

\section{Geological background}

\subsection{Overview}

The Parnaíba Basin is currently `istributed over an approximately circular area, with about $600,000 \mathrm{~km}^{2}$ of which is locntec, ir. north-eastern Brazil (Fig. 2), where it covers part of the states of Piauí, Maranhão, ' s canıins, Pará, Ceará and Bahia (Pereira et al., 2012). Due to its great stratigraphic similariv vith other basins (Gabon, Ghana, Northeast Brazil), some researchers (Milani anc Tıumaz Filho, 2000; Almeida and Carneiro, 2004; Pereira et al., 2012) suggest that the depositional basin scenario could have occupied an area two to three times greater than the basin's current area during the Palaeozoic era. The thickness of the sedimentary column is about 3,500 $\mathrm{m}$ in the depocenter, while the average thickness of the basin is about $2,000 \mathrm{~m}$.

\subsection{Stratigraphic framework}


Kegel (1953) was the first to suggest the Late Devonian age for sediments in the Parnaíba Basin. These sediments make up the upper part of the Pimenteiras, Cabeças, and lowermost Longá formations (Góes and Feijó, 1994; Grahn et al., 2006). The Pimenteiras Fm (than Member) was established by Small (1914) for a $20 \mathrm{~m}$ thick shale sequence near the town of Pimenteiras, in the State of Piauí. Plummer (1948) divided the Pimenteiras Formation into an upper sandy member and a lower shaly member. Andrade and Daemon (1974) assigned a Late Eifelian to Late Famennian age span to the Pimenteiras Formation, whereas Loboziak et al. (2000) do not consider the fully developed part if li- top of the unit to be younger than Early or Middle Famennian.. The upper part $\Omega$ ine tormation is partly developed into finely laminated and radioactive dark shalc which are best developed in the subsurface of the basin and only exposed in outcrops on ts western margin (Loboziak et al., 2000). The maximum thickness of the formatir $n: r$ ver $500 \mathrm{~m}$ in the central part of the basin. A gap corresponding to the Late Givetia. ar $\lrcorner$ earliest Frasnian is present all over the basin, and the upper part of the Pimenteiras Fu "mation is entirely of Late Devonian age (Rodrigues et al., 1995; Grahn et al., 2006). This J ${ }^{\circ}$ nger interval of the formation is hitherto unknown in the eastern outcrop belt of the arnaıba Basin (Melo, 1988). Similar ages for the upper levels of the Pimenteiras Formation 'vf re also obtained recentlty by Andrade et al. (2009) on the western edge of the basi?

The overlying Cabeças Formation was established by Plummer (1948). Beurlen (1965) included its lowermost part in the Pimenteiras Formation, and Aguiar (1971) placed the upper part in the overlying Longá Formation. The Cabeças Formation is here treated in its original sense (Melo and Loboziak, 2003; Grahn et al., 2006) as defined in its type area near Dom Expedito Lopes (formerly the town of Cabeças), State of Piauí. Daemon (1974) and Andrade and Daemon (1974) found evidence placing the formation in the western part of the Parnaíba Basin in the Late Famennian age. Throughout the basin an erosional hiatus separates the latest 
Famennian glaciogenic strata of the upper Cabeças from variably older sediments belonging to the Pimenteiras and lower Cabeças formations, and towards the western margin the former also overlap directly onto metamorphics of the Precambrian basement (Loboziak et al., 2000). The lithology in the lower Cabeças lacks diamictites and differs from the Pimenteiras Formation in that it has a higher content of sandstone beds. In its upper part the Cabeças Formation features a regressive progradation and fast intergradation of alluvial fan, fan delta and fan delta front systems and glacial lobes at the top (Caputo and Crowell, 1985). The maximum thickness (on the eastern flank of the basin) is about $20 \cup \quad \eta$. While no in-situ fossils older than the Famennian have been established in the Cab ça. Fm, shelly faunas from the Middle Devonian occur in outcrops traditionally attributec ${ }^{t} \mathrm{o}$ the lowest part of the formation along the eastern margin of the basin (Melo, 1988). The $\cdot$ fossiliferous sandstones correspond to Kegel's (1953) "Passagem Member", now d at 1?; late early or middle Givetian by Breuer and Grahn (2011), and consist of alterna. ng cempestites, and sigmoidal lobes that are genetically related to the Pimenteiras Fu rmation. The Longá Formation was introduced by Albuquerque and Dequech (1950) for ?ection in the valley of the Longá River, and along the road between Campo Maior ar. Casielo in the State of Piauí. Kegel (1953) and Lange and

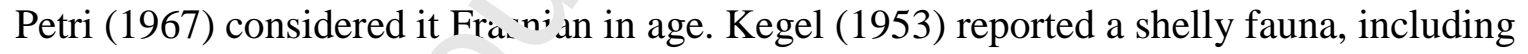
rare Malvinokaffric ele. 'eııs (Melo, 1988), and possible tentaculitids in basal Longá Formation outcrops at the Barreiras Farm, on the eastern flank of the basin. Malvinokaffric faunas became extinct during the early Givetian (Bosetti et al., 2011), and tentaculitids are unknown later than the Frasnian. However, closer inspection of the latter (Melo in Grahn and Melo, 2005) revealed that the alleged "tentaculitids" are in fact serpulitid worm tubes characterized by annular structures. The lower (latest Famennian) part of the Longá Formation (lateral facies to the uppermost Cabeças Fm.) features rhythmites including micaceous, sideritic and well laminated greenish-grey shale with bioturbated interbedded 
siltstone. The formation above (Tournaisian) contains argillaceous, cross-laminated sandstones with conglomeratic horizons, and silty shales and siltstones in the upper part. The total thickness of the formation is about $150 \mathrm{~m}$ (Caputo, 1984). Reworked palynomorphs were found in the lower Longá Formation, in the central and western parts of the basin. This corresponds to chitinozoans occurrences likely to have been reworked and which were reported by Cruz (in Lima and Leite, 1978) from the Valença do Piauí region, on the eastern flank of the Parnaíba Basin.

\section{Material and methods}

The samples that support the geochemical and naly ological analysis of this study were colleted from outcrops located on the western bouı tary of the Parnaíba Basin.

The samples were collected from outcr $>p_{1}$ al, $\mathrm{ng}$ the roads in Tocantins State (Fig. 1). Three outcrops (sites $10,11,12$ ) were dc cr sed in detail at the edge of the road and were stratigraphically positioned (Fig. 2), pru ${ }^{-1}$ ucing a composite stratigraphic section of around 70 meters. Fourteen samples were co ${ }^{11} \mathrm{e}$ ct $2 \mathrm{~d}$ from these sections in the Pimenteiras Formation. In an additional 20 metre thick se : ion (Site 35) of the Pimenteiras Formation thirty-one samples were collected (Fig. 3). Tweı ther samples were collected in site 37 (Fig. 4). They are distributed as follows 1t, the sites: Site 10: samples 5-8; Site 11: samples 9-12; Site 12: samples 13-18; Site 35: samples 48-78; Site 37: samples 80-91. All the samples were processed for geochemical (Tbl. 1) and palynological analysis.

Before sending the samples for TOC and Rock-Eval pyrolysis analyses, they were macerated and powdered at 80 mesh $(0.177 \mathrm{~mm})$, and then acidified with hydrochloric acid, for removal of carbonates.

The TOC of the samples was obtained via Leco SC-632 equipment and reported as a relative weight percentage of the original sample. The Rock-Eval pyrolysis analyses were 
made in a Vinci Technologies pyrolyzer, in accordance with to the procedures of Espitalié et al. (1977). The $\mathrm{S} 1$ (free liquid hydrocarbons present in the rock, in $\mathrm{mg} \mathrm{HC/g}$ rock); S2 (hydrocarbon generating potential of the organic matter present in the rock, in mg HC/g rock); $\mathrm{S} 3(\mathrm{CO} 2$ generated by the organic matter present in the rock, in $\mathrm{mg} \mathrm{CO} 2 / \mathrm{g}$ rock) and Tmax (maximum hydrocarbon generation temperature in ${ }^{\circ} \mathrm{C}$, measured at the maximum height of the S2 peak) were then read. The hydrogen indices $[\mathrm{HI}=(\mathrm{S} 2 / \mathrm{TOC}) \mathrm{x} 100$, in $\mathrm{mg} \mathrm{HC} / \mathrm{g}$ TOC] were also calculated.

The geochemical analyses were carried out in the Laborator, of Chemical Stratigraphy and Organic Geochemistry of the Faculty of Geology of th _ n $)$ de Janeiro State University.

All samples were also processed for palynologiral tudies. This processing was performed by Palynological Laboratory Services, U.Y. . ne samples were first scraped and washed before being crushed to $<1 \mathrm{~mm}$ fragme it $\quad$ A weight of $35 \mathrm{~g}$ was then used for processing.

Samples were treated with $20 \%$ :vdrochloric acid $(\mathrm{HCl})$ until any reactions had ceased. The samples were then left in $h$, $\mathrm{HCl}$ for approximately one hour, to ensure that carbonate digestion was compi: te. 'iney were then topped up with water and allowed to settle for at least one hour, after wh r $^{2}$ time they were decanted. This stage was repeated to bring the samples to a neutraı nh.

Samples were then treated with $40 \%$ hydrofluoric acid (HF) and warmed on a hotplate at $50^{\circ} \mathrm{C}$ for two hours. Next, they were removed from the hotplate and left in the HF for approximately 12 hours to complete the silicate digestion, during which time they were stirred occasionally.

Samples were then topped up with water and sieved over a 10-micron sieve cloth; the collected fraction was brought to a neutral $\mathrm{pH}$ and placed in a Pyrex glass beaker. The samples were then simmered on a hotplate at $100^{\circ} \mathrm{C}$ for approximately 1 hour, before being 
topped up and re-sieved over the 10-micron sieve. The residue was collected and brought to a neutral $\mathrm{pH}$.

The residues were then re-sieved to separate and provide a $10-53 \mu$ and a $>53 \mu$ fraction. The $>53 \mu$ was then placed in a glass vial, as this would not require any oxidation. A representative sample of the $10-53 \mu$ residue was placed in a glass vial to provide a kerogen (pre oxidation) slide.

Most of the samples required a short period of cold concentrated nitric acid, ranging in time from 5 minutes to 10 minutes. One or two of the samples raqui "ed a very short sonication of about 10 seconds, to reduce the amount of organic amor fll 'ts residue present.

Both the $10-53 \mu$ and $>53 \mu$ fractions were mountec in Norland Optical adhesive No61. The slides are housed at the University of Liège, Deparı nent of Geology, EDDy Lab/Palynology.

The different palynomorphs obse. ver. during this study have been photographed and are illustrated on plates I to XV. They in've been grouped by biological affinities: acirtarchs (Pl. I-II), chitinozoans (Pl. III-IV) ^nd $m_{1}$ ospores (Pl. V-XV). A list of all species with their author(s) is provided in the app ndix.

In accordance with the $r$ commendations of the Subcommission on Devonian stratigraphy, Newletter $Y^{\prime} \angle L$ (2007, p.2), in this paper we used the subdivision of the Early Frasnian into Early and Middle Frasnian, to replace of Early and late Early Frasnian.

\section{Results and discussion}

\subsection{Geochemistry data}

According to Rodrigues' (1995) definitions, the geochemical characteristics (Tbl. 1) of the lithological and sedimentological aspects of the outcrops studied (Fig. 2-4), allow for the recognition of the top of Radioactive Shale B in sites 10 and 37. The Radioactive Shale C-of 
the lower part of the upper Pimenteiras Formation-is recognised in site 12 and in the totality of the section recorded in site 35 , as well as in the shales of the upper part of the Pimenteiras Formation in site 11. Theses radioactive shales were originally described by Rodrigues (1995) using geochemistry data and log profiles from wells located in the center of the Parnaíba Basin.

The top of Radioactive Shale B, recorded in site 10, and the lower part of site 37, is characterised by a TOC of around $1 \%$, which implies a good concentration of organic matter. In most of the samples, the S2 values of between 0.69 and $3.00 \mathrm{mg} \mathrm{HC} / \mathrm{g}$ rock, and the hydrogen index of between 70 and $200 \mathrm{mg} \mathrm{HC} \mathrm{/} \mathrm{g} \mathrm{COT,} \mathrm{ir} \mathrm{slc} \mathrm{te} \mathrm{low} \mathrm{source} \mathrm{potential} \mathrm{for} \mathrm{gas.}$

The data of the hydrogen index shows that, in ther.nally immature samples (values of $\mathrm{T}_{\max } \leq 435^{\circ} \mathrm{C}$ ), the organic matter ranges from type IV $\backsim$ type III. This suggests the predominance of degraded terrestrial organic $\mathrm{r}^{\prime} \mathrm{a}_{\imath}$ ar $\mathrm{r}$ ıcording to Jones (1987). This interpretation concurs with the works of 'or' igues (1995) and Rodrigues et al. (1995), who concluded that the shales below Radioa tive Shale $\mathrm{C}$ are characterised by a greater influence of higher plants in terms of organj ${ }^{n} \mathrm{~m}{ }^{\mathrm{t}+} \mathrm{tr}$ composition.

The radioactive Shale $\mathrm{C}$ was recorded in sites 12 and 35 and the middle section of site 37. This interval is character. ${ }^{-a}$ by TOC contents of 1.0 to $6.95 \%$, implying a moderate to high concentration of or ranic matter. The $\mathrm{S} 2$ values of between 1.17 and $11.28 \mathrm{mg} \mathrm{HC} / \mathrm{g}$ rock, and the hydrogen index of between 100 and $336 \mathrm{mg} \mathrm{HC} \mathrm{/} \mathrm{g} \mathrm{COT,} \mathrm{indicate} \mathrm{a} \mathrm{low} \mathrm{to} \mathrm{high}$ potential source of gas and condensate.

Considering that the samples are thermally immature (values of $\mathrm{T}_{\max }<430{ }^{\circ} \mathrm{C}$ ), the hydrogen index data suggests that the organic matter of this interval is heterogeneous, showing a mixture of type IV to type II. However, the literature (Rodrigues, 1995; Rodrigues et al., 1995) shows that the organic matter of Radioactive Shale C is predominantly composed of marine algae. As marine organic matter predominates, it is possible to infer that the lower 
values of the hydrogen content are casually related to the higher proportion of oxidised organic matter. As the radioactive shales $\mathrm{C}$ contains the highest proportion of marine organic matter and the highest total organic carbon contents (sites 12 and 35)—when compared to the Radioactive Shale B and to the upper shales of the Pimenteiras Formation - it can be concluded that they may represent deposits related to the maximum marine flood surface (Rodrigues, 1995) and may therefore represent deeper and more distal areas of terrestrial organic matter influx.

The shales of the upper part of the Pimenteiras Formation $\mathrm{a}_{\mathbf{1}}{ }^{*}$ recorded in site 11, where they come into contact with the Cabeças Formation $11^{\wedge}$ total organic carbon contents range from 1 to $2 \%$, representing a high concentration nf ८ -ganic matter. The S2 values of between 2 and $5 \mathrm{mg} \mathrm{HC} / \mathrm{g}$ rock, and the hydrogen crnı nt of between 150 and $230 \mathrm{mg} \mathrm{HC}$ / g COT, characterise a moderate potential sourre $i \mathrm{c}$ as.

Since the samples analysed are $1 \epsilon$ : \& $t^{\prime}$.ermally developed (values of $\mathrm{T}_{\max }<430{ }^{\circ} \mathrm{C}$ ), the values of the hydrogen index — at aroun. $150 \mathrm{mg} \mathrm{HC} \mathrm{/} \mathrm{g} \mathrm{COT—characterise} \mathrm{a} \mathrm{predominance}$ of type III organic matter. This aljæns vich the findings of Rodrigues (1995) and Rodrigues et al. (1995), which describe a gr ter proportion of higher plants in the composition of the organic matter of the shales a' $\mathrm{a}$ e the Radioactive Shale C.

The geochemist.' Icsults indicate that the Radioactive Shale B of the Pimenteiras Formation - recorded in the outcropping - exhibit a good concentration of terrestrial organic matter, with a low potential source of gas. The Radioactive Shale C of the Pimenteiras Formation, described in sites 12 and 35, has a good to excellent concentration of marine organic matter and is a low to high potential source of gas and condensate. Lastly, the shales of the upper part of the Pimenteiras Formation, recorded in site 11, show a moderate concentration of terrestrial organic matter with a moderate potential source of gas. However, 
the pyrolysis analysis shows that the organic matter contained in the Pimenteiras Formation is thermally immature in all outcrops studied in the southwestern area of the Parnaíba Basin.

\subsection{Acritarchs and other microalgae (fig. 5)}

Müller's (1962) palynozonal scheme, based on the combination of major palynomorph groups (acritarchs, miospores and chitinozoans) for the Silurian-Mississippian interval of the Parnaíba Basin in northeastern Brazil, represents the first attempt at dating the pre-Tertiary sedimentary sequence. Müller's pioneering work was followed h $\iota^{\text {ther }}$ palynological investigations and the proposition of regional zonation by ${ }^{\top} \mathrm{m}_{\mathrm{w}}(1967 \mathrm{~b}, 1971)$; Andrade and Daemon (1974); Daemon (1974, 1976); and Quadros (190? 1988). Since that time, these studies have remained largely unrevised. However, th a $\iota_{\perp}$ portunity offered by a long collaboration with Petrobras in recent years, bs st $r$ ostly on the study of subsurface materials, has enabled us to systematical:" a alyse acritarch assemblages from the Amazon, Parnaíba and Solimões basins, to definc hiostratigraphic subdivisions based on these marine and possibly freshwater planktonir $\mathrm{mi} \cdot \boldsymbol{r}$ floras, and to evaluate their stratigraphic value for the Palaeozoic succession in ce nparison with chitinozoans and miospores. This work is, for the most part confidential. $\mathrm{Y}^{+} \mathrm{t}^{\mathrm{l}} \mathrm{e}$ experience acquired is used here to discuss the biostratigraphic dating \& tue outcrops analysed, complementing the data and chitinozoans and miospores.

Acritarchs and other microalgae are well represented in the samples studied, even though miospores are dominant in some samples. A total of 70 species have been identified (see list in the appendix). Among those definitively identified, are some characteristic species of the Late Devonian. The data obtained enables the subdivision of that interval into two assemblages: the oldest from the Middle to earliest Late Frasnian age; the youngest from the early Late Frasnian age. The palynological results with acritarchs are correlated and largely 
calibrated by available miospores and chitinozoans zonations (Melo and Loboziak, 2003; Grahn et al., 2006) in use in the same regions. As previously mentioned, we take account of the recent subdivision of the Early Frasnian, into Early and Middle Frasnian. This has affected the dating of the local Bpi miospore Zone of Melo and Loboziak (2003), with the upper part now being referred to as the Middle Frasnian instead of late Early Frasnian. This data makes it possible to correlate the assemblages, including acritarchs and prasinophytes, with Late Devonian assemblages documented from the Amazonas Basin (Le Hérissé, 2001), and other regional studies providing information of the stratigraphical distrib tion of some species (Brito and Quadros, 1984 ; Oliveira and Burjack, 1996 ; O'ive'ra and Burjack, 1997 ; Quadros, 1997). We also refer to the unpublished thesic b, Oliveira (1997) and unpublished personal data. The difficulty lay in working with diff $f$ re $_{.}{ }^{+}$outcrops, since we have observed variations in the suites of acritarchs and other ran $n$.gae on a site by site basis — suggesting some variations in their biostratigraphy, . $r$. eviously suggested from the study of miospores. However, the first occurrence of some $\mathrm{s}_{\mathbf{1}}$ ecies, and the associations of species within the different sites, has allowed us to singc at quite an effective resolution in the biostratigraphic analysis.

\subsubsection{First assemblage}

A first assemblage of the Middle to earliest Late Frasnian age is suggested, in the material studied. This is due to the association of the following species-Crucidia camirense (Pl. 1, fig. 7), Duvernaysphaera cruciformis nov. sp. (Pl. 1, figs 14-16), Leiofusa bisubulata (Pl. 2, fig. 6), Mediocorpore conspicuus (Pl. 2, fig. 1), Petrovina connata (Pl. 1, fig. 5), Pseudolunulidia micropunctata (Pl. 1, fig. 8) and Puteoscortum limai (Pl. 2, fig. 5) -in sites 10 and 12, and to the occurrence of Leiofusa bisubulata, Mediocorpore conspicuus, Pseudolunulidia micropunctata and Puteoscortum limai in the lower two-thirds of site 35. 
Comparisons and correlations were made with coeval assemblages known to exist within subsurface successions in the Parnaíba and Amazon basins (Le Hérissé unpublished data). Leiofusa bisubulata which we used in association with other species represented here to characterise the Middle Frasnian is an index species of interest in the eponymous zone. This zone existed prior to the Late Frasnian and overlaps with it and is marked by a consistent occurrence of Maranhites spp. with internal dots. The first specimens of this group appear sporadically in the upper part of the Leiofusa bisubulata zone.

The Leiofusa bisubulata Interval Zone encompasses the main part of the radioactive shale interval of the Parnaíba Basin (Frasnian anoxic event oi Rodrigues, 2001; Rodrigues et al., 1995), with equivalents in the lower Frasnian of the A. azonas Basin (Barreireinha Formation). However, even though good components or the radioactive shales, such as the large Tasmanites and leiospheres are well repr su te $\mathrm{d}$ in some samples, such as in site 12 but also higher, we never have an over-repre : $\mathbf{n}^{+}$ation of these elements compared to the Amazonas basin. This fact along with si me of the other biostratigraphical results detailed below, might suggest that we are ahov ne interval with a maximum of radioactive shales.

The occurrence of Cruc: dia camirense and Petrovina connata at the base of site 10 suggests that these samples $a_{1}{ }^{2}$ r ot of earliest Frasnian age. This is because the oldest records of the two species are $1 t^{\text {th }}$ upper part of the Leiofusa bisubulata biozone in other sections of the Parnaíba Basin (based on unpublished data), and this is also reflected in the reference core RSP-1 of the Paraná Basin, where Petrovina connata was defined (Burjack and Oliveira, 1996)

Important additional species in the first interval, which were distinguished in this study include: Advenasphaeridium australis (Pl. 2, fig. 4), A. acerosum, ?Chomotriletes sp. (a new form, Pl. 2, figs 7-9), Diaphorochroa gracile (Pl. 2, fig. 11), Duvernaysphaera cruciforme nov. sp. (Pl. 1, figs 14-16) associated with D. angelae/tessella (Pl. 1, figs 17) and 
well represented, D. radiata (Pl. 2, fig. 2) , D. tenucingulata, Estiastra spinireticulata (Pl. 2, fig. 16), Exochoderma arca, Geron elegans, Hemiruptia legaultii, Leiofusa fastidiona, common Maranhites (without dots) with Maranhites brasiliensis (P1. 1, fig. 1), M. lobulatus, M. magnus, M. primus, M. stockmansii (Pl. 1, fig. 3), some Navifusa bacilla (P1. 1, fig. 9) with the crescentic variants and the long and fine $N$. bacilla var. procera, Naevisphaeridium sprucegrovense (Pl. 2, fig. 12), Polyedryxium fragosulum, P. pharaone, Pterospermopsis pernambucensis, Tinacula simplex (Pl. 2, fig. 19), Umbellasphaeridium deflandrei (Pl. 1, fig. 11), U. saharicum, Unellium ampullium (Pl. 2, fig. 10), U. pirifnrm. and some triapsidate Veryhachium.

\subsubsection{Correlation with previous regional zonation}

In the Parnaíba Basin, the Leiofusa bisı bı. at zone encompasses the combined upper part of the Samarisporites triangulatus (' ' $r g$ ', which is not represented here, the Verrucosisporites bulliferus-Geminosp " "a piliformis (Bpi) and the lower part of the Rugospora bricei-Diducites mucrnnat.'s (BMu) miospore zones of Melo and Loboziak (2003). It corresponds to the L. vvelınoi chitinozoan zone (Grahn et al., 2006). The higher part of the local Bpi miospore 70ı $i$, now reassigned to the Middle Frasnian. The Early to early Late Frasnian strata of $`$ i arnaíba Basin correspond to Müller's (1962) palynozone Q, at least — as well as to the transition between interval V and VI, sensu Daemon and Contreiras (1971), Andrade and Daemon (1974) and Daemon (1974, 1976).

\subsubsection{International correlations}

Umbellasphaeridium saharicum, also recently registered by Andrade et al. (2020) in the upper levels of the Pimenteiras Formation in the southwestern border of the Parnaíba Basin, while never abundant, is of interest in the zone - as a complement to the eponymous 
species and other key taxa-because of its stratigraphic value as an Upper Devonian index in the Brazilian Palaeozoic basins (see also Melo, 2005). It is consistent with the Frasnian through Strunian (Zones L5-L7) range of the species in the Algerian Sahara (Jardiné, 1972; Jardiné et al., 1974). In Ghana, in some successions which are somewhat equivalent to the succession in the Parnaíba and Maranhão Basin, the species is recorded in the Frasnian (Bär and Riegel, 1974). It is also an important species present in the Frasnian assemblage SA3 of Argentina (Noetinger and Di Pasquo, 2011). The first record of the species was certainly by Regali (1964), in the Tucano-Jatobá Basin of northeastern Brazil The said occurrence, first dated as Middle (?) Devonian by Regali (1964),-was later r - 11 : -rpreted as Frasnian by Brito (1976) and as Strunian by Quadros (1980) and Dino et al. (?011). Another historical record is in the Mac-Mahon Basin, in the upper Famennian-Stranı ’n, as "acritarche à entonnoirs" $\mathrm{N}^{\circ}$ 441-33 by Lanzoni and Magloire (1969). Tr e . crate stratigraphic distribution of Umbellasphaeridium saharicum in the U S. $/$ is more complex, since the material is

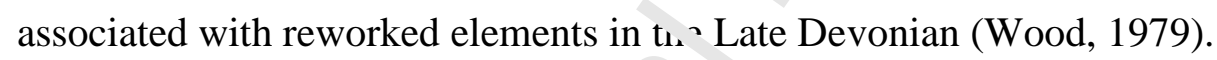

There is a good correlation 'vit ' ne Late Devonian of Argentina, particularly the Los Monos Formation assemblages tesciibed in the Tarija Basin. Many of the species recorded by Ottone (1986) occur in the Li in asa bisubulata biozone, such as: Leiofusa bisubulata (as Leiofusa sp. Pl.7, figs. i, $>$ in Ottone) (Pl. 2, 6), Maranhites mosesii (Pl. 1, 4) and Pseudolunulidia spp. The re-description of Crucidia camirense (Pl. 1, fig. 7) in Argentina is also noteworthy, after the species was first illustrated in Bolivia by Boneta (1975). With the presence of Crucidia camirense in Argentina, among other elements in Argentina, we consider the age of these Argentinian assemblages as most likely early Late Frasnian, rather than Late Givetian to Early Frasnian as suggested by Ottone (1996).

As discussed earlier, direct comparisons are also possible with the Paraná Basin and the reference RSP-1 borehole, previously studied by Burjack et al. (1987), Loboziak et al. 
(1988), and Oliveira (1997). Many of the species found in the Leiofusa bisubulata biozone were described for the first time in the RSP-1 core-drill (Oliveira and Burjack, 1996; Oliveira and Burjack, 1997), yet many species are still nomen nudum. The equivalent of the Dc-Lb Zone is the interval between $60.50 \mathrm{~m}$ and $200 \mathrm{~m}$. Species in common include Advenasphaeridium acerosum (nomen nudum), A. australis (nomen nudum) (Pl. 2, fig. 4), Crucidia camirense (Pl. 1, 7), Diaphorochroa gracile (nomen nudum) (Pl. 2, fig. 11), Naevisphaeridium hercyniana, Leiofusa bisubulata, Petrovina connata (Pl. 1, fig. 5), the

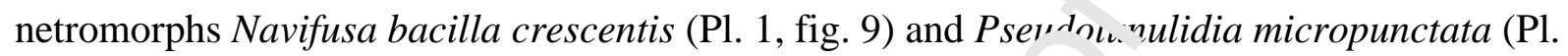
1, fig. 8).

\subsubsection{Second assemblage}

The stratigraphically higher assemblag i de ined in the last three samples of site 35 the last four samples of site 11 and up to ar ple 86 in site 37 . It contains significant species

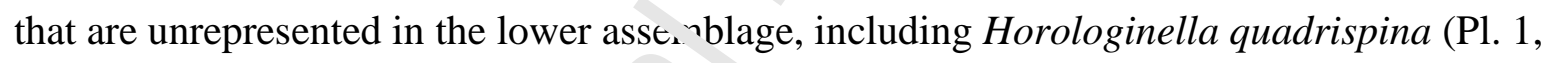
figs 12-13), Maranhites mosesii, P«eu. Ir naranhites densus, Pterospermopsis crassimarginata (Pl. 1, fig. 6), Veryhachium $c a_{1}{ }^{\prime}$ tata nov. sp. (Pl. 2, fig. 17), Veryhachium insanum nov sp. (Pl. 2, fig. 18) and V. pannucivr $\iota$.

In the Amazon L'ası, the succession of Veryhachium insanum, Bipolarisvelata accreta and the introduction of Horologinella quadrispina is observed in the reference core Caima PH-2 (Le Hérissé, 2001; Le Hérissé, Longhim, Melo, in prep.), at the boundary between Middle and Late Frasnian. It corresponds also to an interval marked by the appearance of Maranhites mosesii.

The order of appearance of some of these species is also the same in the upper part of the RSP-1 core in the Paraná Basin (see Oliveira, 1997, Fig. 18). But the material does not include the introduction of Horologinella quadrispina (Pl. 1, figs 12-13). 
Pterospermopsis crassimarginata is also a common component of the zone, but it can be mentioned as a precocious appearance of this species in the Paraná Basin, where it has been defined for the first time.

Puteoscortum williereae is the index species of Zone Pw (Vanguestaine et al., 1983) and is characteristic of the lower Famennian in Belgium. Our data points to an earlier introduction of the species in the Frasnian of Brazilian successions, whereas its regional exit is in the Middle Famennian.

In terms of correlation with previous regional zonation the igher assemblage recognised here will be equivalent to the lower part of the ${ }^{r} \cdot u_{\mathrm{\delta}}$ 'spora bricei-Diducites mucronatus (BMu) zone of the Late Frasnian age, accord ${ }^{\circ}$ o to Melo and Loboziak (2003) and Grahn and Melo (2006).

\subsection{Chitinozoans}

Devonian chitinozoans from the Darnaíba Basin were first discussed by Müller (1962). His Silurian through Lower Carbonife $*$ is Biozones were divided into seven zones, ranging from $\mathrm{N}$ (upper Visean) to $\mathrm{T}$ ( $\mathrm{u}_{\mathrm{F}_{1}}$,er silurian), based on chitinozoans, spores and acritarchs. The Pimenteiras Formation c.rr sponds to his Zone Q (upper Zone R-P by Brito, 1967, 1971 and Q-P by Quadros, $1{ }^{\prime} \vee_{L}$ ). These zones were, until recently, regarded as a reference palynomorph biozonation for the Parnaíba Basin (e.g. Brito, 1967, 1971; Daemon, 1974, 1976; Quadros, 1982, Molyneux et al., 1996). Daemon refined the Silurian - early Carboniferous sequence into 12 biozones based on miospores. In his scheme, the upper zones 5 and 6 correspond to the Pimenteiras Formation. Sommer and Van Boekel (1964) described Middle Devonian chitinozoans from outcrops of the lower Pimenteiras Formation on the western margin of the Parnaíba Basin. Concurrently, Daemon (1964) formulated a generalised chitinozoan biostratigraphy for the basin using Müller's zonal scheme as a framework. Lange 
(1967) briefly mentioned chitinozoans from the Parnaíba Basin, and Cruz and Quadros (1985) described a new chitinozoan species from the latest Frasnian - early Famennian. More recently, chitinozoans have been discussed and correlated with miospores in papers by Grahn et al. (2001, 2005, 2006, 2008) and Breuer and Grahn (2011). The Pimenteiras Formation consists of a lower Middle Devonian section, separated by a hiatus from the upper Late Devonian section.

The chitinozoans encountered in the present study constitute a characteristic Frasnian assemblage, although not earliest or latest Frasnian. They are tvinica ${ }^{1}$ for the early to early Late Frasnian Angochitina (Lagenochitina) avelinoi (Pl. 3. 11.. 1-2) regional interval range zone of the Parnaíba Basin, which corresponds to the lnwe- Hoegisphaera glabra global interval range zone (Paris et al., 2000). Angochitina ron:ai (Pl. 3, figs 3, 4) and Angochitina avelinoi (Lange, 1952) are recorded in the Late $\mathrm{L} \cdot \mathrm{vr}$, nian of the major intracratonic basins of Brazil. The latter species has a more rest. ${ }^{i} \mathrm{ct} \_\mathrm{d}$ range in the Paraná (early Late Frasnian) and Amazonas Basins (early Frasnian). In $\iota_{\star}$ • Parnaíba Basin, there is a variety of Angochitina mourai with a long neck, common in the early Late Frasnian. Lagenochitina sp. A in Grahn and Melo (2005) (Pl. 4, figs 5-〔' alung with similar specimens, are recorded from the early Frasnian but are also commo. ir the early Late Frasnian. Fungochitina pilosa (Collinson and Scott, 1958) (Pl. 4, figs 1 L) is something of a vast basket, and specimens like Fungochitina pilosa have been recorded from the late early Eifelian to the Frasnian. Lagenochitina sommeri (Lange, 1952) (Pl. 4, figs 3-4) was first described from the early Frasnian in the Amazonas Basin, but also occurs in the early Late Frasnian of the Parnaíba Basin. Both Angochitina sp. C and Fungochitina microspinosa (Grahn and Melo, 2005) (Pl. 3, figs 9-10) are common Frasnian species in the Parnaíba Basin. Although an early Frasnian age cannot be excluded, the chitinozoans present are altogether more similar to an early late Frasnian age. 


\subsection{Miospores}

\subsubsection{Results}

Several studies on miospores are available for the Frasnian of the Parnaíba Basin. Most have been carried out by Loboziak and his co-authors (e.g., Burjak et al., 1987; Dino et al., 1996; Grahn et al., 2006, 2008; Loboziak et al., 2000; Loboziak et al., 1994; Loboziak et al., 1992b). Few papers describing the whole Frasnian assemblage of outcrops or cores from the western Gondwana are available.

The miospores observed here are well preserved, and yellow to pale brown in colour. The assemblages are rich and diverse. The most prolific sa 11 is in miospores are the $\mathrm{N}^{\circ}$ AM7, AM8, AM9, AM89 and AM95. Samples AM50 A. 153, AM55, AM60, AM65, AM70, AM80, AM85 and AM88 contain rare miospores. In alı ne samples, miospores are more abundant than marine palynomorphs, especiall $/ \Lambda_{1}$ tr 2 upper part of the section where acritarchs are rarer. This decrease in the "la tity of acritarch input has also been noted in the upper part of the Pimenteiras Formation of the Well 2-PM-1-MA (Loboziak et al., 1992b), probably corresponding to a regrescioi

Weak variations in the $\mathrm{smpusition}$ of the assemblages have been observed throughout the sequence, except for very minor differences. Moreover, as the different sections are being separated by outcrop $g_{a_{\mathfrak{i}}} \uparrow$, uneir lateral geometrical relationship is somewhat difficult to achieve.

The richest levels in miospores contain more or less the same assemblage in which the most helpful species for biostratigraphy are known from the classical Boulonnais area from Northern France (Streel et al., 1987, Loboziak and Streel, 1988). Among them, the following species have been observed: Samarisporites triangulatus (pl. 15, figs 1-3), Chelinospora concinna (Pl. 7, figs 6-9), Verrucosisporites bulliferus (Pl. 15, figs 4-6), Lophozonotriletes media (Pl. 13, figs 9-10), etc. These suggest the Frasnian age. The oldest sample from the site 
10 (AM7) already contains, among others, Verrucosisporites bulliferus (Pl. 15, figs 4-6) and Lophozonotriletes media (Pl. 13, figs 9-10)

In the Boulonnais area of northern France (Streel et al, 2000), miospores occur in the same sections as conodonts. The chronostratigraphic limits of the Frasnian stage, fixed on conodonts in the Montagne Noire area, can thus be transferred to the Boulonnais area. In this area, Chelinospora concinna and Samarisporites triangulatus-which characterise the TCo Zone - first occur in the upper Givetian but are still present in the Early and Middle Frasnian. Verrucosisporites bulliferus first occurs in the early Frannia. and Lophozonotriletes media in the Middle Frasnian (BJ and BM Zones), but bott an stll present in the upper Frasnian and the Famennian. Rugospora bricei, Grandisn "a gracilis and Diducites plicabilis (BA Zone or Regional "IV" Zone) first occur success:Vc:v in the upper Frasnian but are still present in the Famennian (Streel, 2009).

A Middle to Late Frasnian (but $n+1$ l rest) age is therefore suggested for all the studied samples.

\subsubsection{Discussion}

\subsubsection{Correlations with $\mathrm{L} \cdot \mathrm{m}$ silian biostratigraphic scale (Fig. 6)}

Miospores from 'he vivetian to the Tournaisian have been studied by Loboziak et al. (2000) in the Tocantins Valley of the Parnaíba Basin located some $120 \mathrm{~km}$ away from the sections studied here. The biozones from the Boulonnais area (Streel et al. 1987), ranging from TCo to BM-“IV"(or BA Zone), were used in this paper as well as in Loboziak and Melo (2002). New biozone names (BPi -BMu-TP) were introduced later by Melo and Loboziak (2003) in the Amazon Basin. Among the Tocantins Valley samples from the Pimenteiras Formation, 12 are shown to belong to the Frasnian. A total of 32 taxa have been identified in these 12 samples including 9 taxa which are restricted to the Frasnian. From our samples there 
are only 15 taxa in common with these 32 taxa recorded in the Tocantins Valley. 7 of the 32 taxa are also known in the Cabeças Formation belonging to the Latest Famennian where they are "ascribed to reworking on the basis of differential preservation or color" (Loboziak et al., 2000, p. 308). However, it is possible to correlate the two areas, thanks to the species Lophozonotriletes media, Grandispora tabulata (Pl. 13, figs 1-2), Verrucosisporites bulliferus and Samarisporites sp. C (synonym of S. sp. E in Melo and Loboziak, 2003) (Pl. 14, figs 1012).

In the samples studied herein, Verrucosisporites bullifer's ic one of the eponymous species of the BPi Interval Zone-along with Geminospor - pi ${ }^{\prime}{ }^{i}+o r m i s$ - according to the biozonation established in Brazil by Melo and Loboziak ( 203$)$. This biozone is marked by the FOB of Verrucosisporites bulliferus. The analysed su mples should thus belong to the BPi Interval Zone in Brazil, despite the absence of $\mathrm{\jmath t}$ er ation of Geminospora piliformis - $\mathrm{a}$ species that is poorly scattered and contr. 1le. . However, Melo and Loboziak (2003) note that in the Paraná Basin’s Ponta Grossa For.`ation, Geminospora piliformis appears with Lophozonotriletes media in the upner $\_. t$ of the zone, allowing the zone to be subdivided into two parts, and demonstrates a c vrelation of this higher interval with the BM Oppel zone of Western Europe. The BPi Zo. ' ' 'as also been observed in the Amazon Basin, and probably also in the Solimões Ba in within the Jandiatuba and Uerê Formations.

Rugospora bricei is a species appearing in Biozone BA (ex "IV" Refional Zone) in Western Europe (Streel et al., 1987). This species is also known in Brazil and appears close to the base of the BMu Biozone (Melo and Loboziak, 2003). The species has been identified in the Parnaíba, Amazon, and Paraná Basins (Burjack et al., 1987; Grahn et al., 2006; Melo and Loboziak, 2003). Two specimens like Rugospora bricei have been observed in site 10, samples 7 and 8 . However, the nature of the convolute proximal muri is different to those of the original species; they are too coarse. Thus, the two specimens are here considered as 
Rugospora cf. Rugospora bricei (Pl. 14, figs 7-8)- Rugospora bricei is also close to

Rugospora radiata. The main differences are in the size and arrangement of the rugulae in Rugospora flexuosa are much coarser (Higgs et al., 2013). These last two species are known in the Famennian.

Among other important species for the biostratigraphy, Camarozonotriletes concavus (Pl. 7, figs 4-5) first appears in the Eifelian and is supposed to have disappeared close to the BJ-BM boundary (Loboziak and Melo, 2002). Grandispora tabulata first appears just below $V$. bulliferus and is known up to the Famennian (Loboziak et al 15?9). Auroraspora macra (Pl. 7, figs 1-3), which has been known since sample 7, fir $\iota a_{1}$ nears at the boundary between Biozones BM and BA (ex "IV" Regional Zone) (Lobozian et al., 1988) and is known up to the Tournaisian (Zwan, 1980).

Most of the spores are geographically c ss. in, olitan, except for some species that are restricted to the Gondwana like Gemino ${ }_{\Perp}$ ?or ^ piliformis, Grandispora gabesensis, Grandispora libyensis (P110, figs 6-7) and Grandispora tabulata.

\subsubsection{Correlation with the Eurupean biostratigraphic scales (Fig. 6)}

Givetian to Lower Fan' ne' nian deposits, containing miospores, are widespread on the territory of the Pripyat L ${ }^{-} p_{1}$ ession in SE Belarus and the Timan -Pechora Province in Russia. The biostratigraphy of these deposits is based also on conodonts in the Timan-Pechora (see in Streel et al., submitted).

Correlations during the Late Givetian to Middle Frasnian between Boulonnais and Eastern Europe are shown to be obvious from varcus to punctata conodont Zones. They are less obvious from the Middle Frasnian to the Early Famennian (Obukhovskaya, 2000; Streel et al., 2000; Telnova, 2008; Telnova et al., 2019) 
Geminospora lemurata (Pl. 9, figs 5-6) is well known and distributed worldwide, appearing just above the Eifelian / Givetian boundary. This species characterises the Lem Interval Biozone (Streel et al., 1987). Samarisporites triangulatus first appears in the late Givetian and is the eponymous species of the TA and TCo Biozones (Streel et al., 1987) in Europe. The species may reach the Tournaisian in both Brazil and Tunisia (Loboziak et al., 1992a; Loboziak et al., 1988; Melo and Loboziak, 2003). Chelinospora concinna, the second eponymous species of the TCo Biozone, appears below the Givetian / Frasnian boundary. Verrucosisporites bulliferus appears above the base of the Frasnian and characterises Biozones BJ and BM (Streel et al., 1987), which are both i cr ded in the lower part of the Frasnian. Finally, Lophozonotriletes media is characteristı of the BM Biozone (Streel et al., 1987), around the Middle Frasnian.

The synthesis of miospore based on Give an io Famennian biostratigraphy in the Boulonnais (Loboziak and Streel 1988) ¿ d ' ot provide detailed analysis of the data accumulated by Loboziak et al. (1983) in the Upper Frasnian. Restudy of this data and new

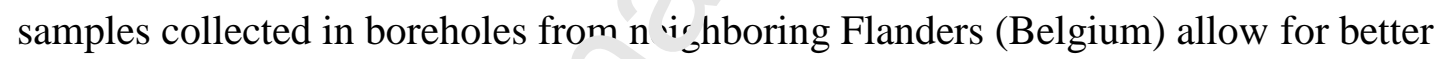
characterization of the transitic. froın Middle to Lowermost Famennian and a comparison with contemporary Eastern E.rrs pe miospores based zonations. (Streel et al., 2020 submitted). The correlation at the b:1/vA transition dated Upper Frasnian by the rhenana conodont Zone in Eastern Europe points to the inaccuracy of the Ferques succession and Hydrequent Formations with regard to tracing the base of the Upper Frasnian in the Boulonnais. A first look at the many recorded ranges of taxa immediately suggests, in the first instance, a sampling gap between these formations. Obviously, it also suggests a deep change in the vegetation cover occurring at that level corresponding more or less to the Lower Kellwasser Event (LKW) starting in the lower rhenana conodont Zone (Becker et al. 2016). 
If the Melo and Loboziak's (2003) correlation of the Brazilian BPi Zone with the West European BJ and BM Zones makes sense, alignment of the base of the Brazilian BMu Zone with the base of the West European BA (ex "IV") Zone is not secure. Nevertheless the FOB in the Pimenteiras Formation of Auroraspora macra, Samarisporites sp C in Loboziak, Streel and Vanguestaine 1983 (synonym of S. sp. E in Melo and Loboziak 2003) and possible Rugospora bricei occurring within the lowermost part of BA Zone (ex IV a-b or BA pregracilis subzone in Streel 2009) confirm the presence of an early part of the Upper Frasnian.

\section{Geochemistry and maximum flooding surface}

Some authors (Myers, 2004; Sutton et al., 2004 • Lining et al., 2004; Rodrigues, 2005; and references therein) have described the relationship $\mathrm{s}^{\mathrm{t}}$ ween TOC content and the stratigraphy of sequences. Organic matter pres ${ }^{\prime} \cdot{ }^{\prime}+i^{\prime}, n$ in the sedimentary record depends on many factors. Myers (2004) pointed out nat he most important factors are the physiogeography of the basin, climate, s arrestrial organic productivity, marine aquatic organic productivity, oceanic circulation, sadi $\cap$ ntation rate and water depth. With the exception of climate and oceanic circulation, the uther factors described by Myers (2004) are influenced by relative sea level change.

Under lowstand c nuitions, the high sediment influx product, the dilution of the organic marine matter content and the organic terrestrial matter are highly oxidised. In this context, the amount of organic matter preserved in the sediments is low and the consequent TOC values are inexpressive.

In the transgressive system tract, the rapid increase in relative sea level caused the shoreline to retreat landward. It resulted in a progressive extension of the shallow marine shelf deposition, and in a reduction of the clastic sediment supply. According to Lüning et al. (2004), the transgression has likely led to sediment starvation because the detritus became 
trapped in river mouths, thus preventing the dilution of the organic matter on the shelf. These conditions led to the progressive the expansion of the deep distal area of the basin until it reached the maximum flooding surface (MFS). In this basin, therefore, there was an extension of the anoxic conditions, which permitted an increase in the preservation of organic matter. The retreat of sediments at the shoreline decreased the dilution of organic matter in the depositional setting. In contrast with the lowstand conditions, the TOC values increased, reaching a maximum at MFS.

As also observed in the section studied in this work, Creant, and Passey (1993) noted that many marine source rocks are characterised by an init' a chrupt upward increase in organic content, which, in contrast with background valıt and a subsequent gradual decrease in organic content (Myers, 2004). The authe"s ¿ tributed this pattern to the control of the organic carbon contents by the clastic sedir 1 t ta ${ }^{4}$ on rate, under anoxic bottom water conditions. The rapid increment of TOC es $^{\prime}$.ts from the retreat of the sediments in the source, during the transgression. The su'sequent gradual decrease in TOC reflects the increase in the clastic sediment surnly a d the dilution of organic carbon during highstand progradation. In this context, $\mathrm{t}_{\mathrm{i}} \cdot \mathrm{Mr} \mathrm{S}$ is positioned at the turning point of the TOC curve. Most authors consider it to bu n'rtly contained in the lower highstand, and partly in the upper

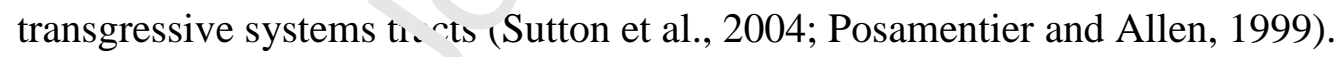

This succession is well defined in the section studied, where the TOC ranges from low to moderate in site 10 (Figure 03). In the subsequent interval (site 12), associated with Radioactive Shale C, the TOC shows an abrupt increase, defining the improved conditions for organic matter preservation. These conditions mark the maximum flooding surface. This interval is also observed at the base of site 35 . In the interval above (site 11), the TOC decreases towards the Cabeças Formation, which indicates the start of the regression system and the consequent increased inflow of sediment toward the basin. 


\section{Conclusions}

The palynological results— based on acritarchs, chitinozoans and miospores — are relatively well concordant, and correlatable with Devonian palynozones in use in northern Brazilian basins.

The occurrence of several species of acritarchs_-such as Leiofusa bisubulata, Mediocorpore conspicuus and Pseudolunulidia micropunctata -in sites 10 and 12, and in the lower $2 / 3$ of site 35 , have made it possible to distinguish a first assu . earliest Late Frasnian age.

In the last three samples of site 35 and the last four samples of site 11, and from site 37 up to sample 86, we observe the occurrence of Horol $g_{\iota} \cdot$ olla quadrispina, Maranhites mosesii, Pseudomaranhites densus, Pterosperr i ${ }_{\star}$ sic crassimarginata, Veryhachium capitata nov. sp., Veryhachium insanum nov. sp. .nd V. pannuceum. This points to a late Frasnian age, quite equivalent to that of the miospore Riozone Rugospora bricei-Diducites mucronatus $(\mathrm{BMu})$.

The chitinozoans that $\mathrm{w}$ re 1cientified in the different slides belong to a common assemblage characteristic of she Frasnian and, more precisely, neither the earliest nor the latest Frasnian. They bc' 'ny to the early-early Late Frasnian Angochitina (Lagenochitina) avelinoi regional interval range zone of the Parnaíba Basin. This is equivalent to the lower Hoegisphaera glabra global interval range zone, which is the second and youngest global chitinozoan biozone of the Frasnian. The miospores do not show variations in the different samples and have been studied as a whole and unique assemblage. Species like Verrucosisporites bulliferus and Lophozonotriletes media clearly demonstrate a mid-Frasnian age. The analysed samples would belong to the BPi Interval Zone and possibly an early part of the BMu Zone in Brazil. 
The present work has characterised the global marine flooding surfaces (FS) recorded in the Devonian section of the Brazilian Palaeozoic basins as seen in the Parnaíba Basin, using the geochemistry parameter Total Organic Carbon content (TOC) and Pyrolysis data.

Two intervals of interest were recorded, according to their TOC content, in the Devonian section we studied. These were Radioactive Shale B and Radioactive Shale C, recorded in the Pimenteiras Formations (latest Eifelian to late early Givetian in the lower part and Frasnian, but not earliest, to Famennian in the upper part), which are richest in organic matter concentration. The proxies studied in this work show a roolu al distribution in the basins - probably associated with a coeval anoxic / dysoxi u nositional condition over a large area of the basin.

The Late Devonian sections presented in this tuc y demonstrated that progressive flooding took place during Devonian era in the F. nn .íba Basin-which, in the Frasnian, shows the maximum marine transgressic. $T_{\text {nese }}$ global events are regarded as markers for regional chronostratigraphic correlation. in Gondwana.

This global event is also an $\neg b_{j}{ }^{a_{i}}$ of interest for hydrocarbon exploration, as it relates to the identification of source 1 - $\mathrm{k}$ 1utervals. However, the conditions for oil and gas generation for this basin are c's ely related to the specific evolutionary model, for which the atypical model is the mu $\mathrm{c}$ urective.

\section{APPENDIX}

List of species encountered in the material and/or cited in the text

$\underline{\text { Acritarchs }}$

Advenasphaeridium acerosum Burjack and Oliveira apud Oliveira, 1997, nomen nudum Advenasphaeridium australis Burjack and Oliveira 1997, nomen nudum Arkonites bilixus Legault 1973 
Bimerga bensonii Wood, 1995

Bipolarisvelata accreta Burjack and Oliveira apud Oliveira, 1997, nomen nudum

Chomotriletes sp.

Crucidia camirense (Lobo Boneta) Ottone, 1996

Diaphorochroa gracile Burjack and Oliveira apud Oliveira, 1997, nomen nudum

Disparifusa urariaensis Le Hérissé, 2013, nomen nudum

Duvernaysphaera angelae $(=$ D. tessella) Deunff, 1964

Duvernaysphaera capitana (Wicander) Le Hérissé nov.comb

Duvernaysphaera cruciformis Le Hérissé, 2001, nomen nи ıиı.

Duvernaysphaera heliocentrica Burjack and Oliveira anu.' Oliveira, 1997

Duvernaysphaera radiata Brito, 1967a

Duvernaysphaera stellata Deunff, 1964b

Duvernaysphaera tenuicingulata Staplir, 10,1

Eisenackidium triplodermum (Cramer) Fisenack et al., 1973.

Estiastra spinireticulata Oliveira and 2r rjack, 1997

Exochoderma arca Wicander a.d Wood, 1981

Exochoderma irregulare Wis der, 1974

Geron elegans Oliveira ’nu Burjack, 1997

Gorgonisphaeridium winslowiae Staplin et al., 1965

Hemiruptia legaultii Ottone, 1996

Horologinella horologia (Staplin) Jardiné, Combaz, Peniguel and Vachey, 1972

Horologinella quadrispina Jardiné, Combaz, Magloire, Peniguel and Vachey, 1972

Leiofusa bisubulata Brito and Quadros, 1984

Leiofusa fastidiona (Cramer and Díez) nov. comb.

Maranhites brasiliensis Brito, 1965 emend Burjack and Oliveira 1989 
Maranhites britoi Stockmans and Willière, 1969 R5+R6+R7+R8

Maranhites lobulatus Burjack and Oliveira 1989

Maranhites magnus Burjack and Oliveira 1989

Maranhites mosesii (Sommer, 1956) Brito,1967

Maranhites stockmansii (Martin) Martin, 1984

Mediocorpore conspicuus Burjack and Oliveira apud Oliveira, 1997, nomen nudum

Multiplicisphaeridium ramusculosum (Deflandre) Lister, 1970

Naevisphaeridium desiderata (Burjack and Oliveira apud Oliveira, 1997) nomen nudum nov.

comb

Naevisphaeridium sprucegrovense (Staplin, 1961) nov cu.nb.

Navifusa bacilla (Deunff) Playford, 1977

Navifusa bacilla (Deunff) Playford, 1977 form ג cercentis

Navifusa bacilla var. procera (Deunff, 1, 46 , nov.comb.

Palacanthus ledanoisii Deunff, 1957, en nend Playford, 1977

Petrovina connata Oliveira and Bיria k, 1996

Polyedryxium embudum Cram. r, 1s64

Polyedryxium fragosulum Pla, vfr,rd, 1977

Polyedryxium pharaone Tsunff, 1961

Polyedryxium sp. or Muraticavea munifica Wicander and Wood, 1981

Pseudolunulidia micropunctata Brito and Quadros, 1984

Pseudomaranhites densus Quadros, 1996

Pterospermopsis crassimarginata Burjack and Oliveira apud Oliveira, 2007, nomen nudum Pterospermopsis pernambucensis (Brito) Eisenack et al., 1973

Puteoscortum limai Burjack and Oliveira apud Oliveira, 1997

Puteoscortum williereae Martin, 1981 
Pyloferites sp.

Stellinium comptum Wicander and Loeblich, 1977

Stellinium divisum Le Hérissé, 2013, nomen nudum

Stellinium micropolygonale (Stockmans and Willière) Playford 1977

Stellinium oppidum Deunff, 1980

Tasmanites spp.

Tinacula simplex Quadros, 1999

Tunisphaeridium tentaculaferum (Martin) Cramer, 1971

Tyligmasoma sp. A of Playford in Playford and Dring, 198'

Umbellasphaeridium deflandrei (Moreau-Benoit) Jardine `` al., 1972

Umbellasphaeridium saharicum Jardiné, Combaz, $\mathbf{M}_{\lambda g_{1}}$ re, Peniguel and Vachey, 1972

Unellium ampullium Wicander, 1974

Unellium lunatum (Stockmans and Willi.re 1966) Eisenack et al., 1979

Unellium piriforme Rauscher, 1969

Veryhachium arctatum Deunff, 1980

Veryhachium capitata Le Héri。 'é, ‘ù01, nomen nudum

Veryhachium insanum Le H七. ‘scé, 2001, nomen nudum

Veryhachium pannuceu." vi icander and Loeblich Jr., 1977

Veryhachium roscidum Wicander, 1974

Veryhachium trispinosum (Eisenack) Deunff, 1966

Veryhachium trispinosum/roscidum complex

Winwaloeusia distracta (Deunff) Deunff, 1977

\section{$\underline{\text { Chitinozoans }}$}

Angochitina avelinoi (Lange, 1952)

Angochitina mourai (Lange, 1952) 
Angochitina sp. C ? Grahn and Melo, 2005

Lagenochitina sp. A Grahn and Melo, 2005

Fungochitina microspinosa Grahn and Melo, 2005

Fungochitina pilosa Collinson and Scott, 1958

Lagenochitina sommeri (Lange, 1952)

\section{$\underline{\text { Miospores }}$}

Auroraspora macra Sullivan, 1968

Camarozonotriletes concavus Loboziak and Streel, 1988

Chelinospora concinna Allen, 1965

Cyrtospora tumida Breuer and Steemans 2013

Diducites plicabilis Van Veen 1981

Geminospora lemurata Balme emend. Playford, $9 \varsigma 3$

Geminospora piliformis Loboziak et al., $19^{`}, 8$

Grandispora gabesensis Loboziak and L'treel, 1989

Grandispora gracilis (Kedo) Stree ${ }^{1}$ in R :cker et al. 1974

Grandispora libyensis Moreau Benuit, 1980

Grandispora tabulata Lobozi $\urcorner$ k and Streel, 1988

Lophozonotriletes meaı' ' augourdeau-Lantz, 1967

Rugospora bricei Loboziak and Streel, 1988

Rugospora flexuosa (Jushko) Streel in Becker et al., 1974

Rugospora radiata (Kedo) Byvscheva, 1985

Samarisporites sp. C in Loboziak et al., 1983

Samarisporites triangulatus Allen, 1965

Verruciretusispora magnifica (McGregor) Owens, 1971

Verrucosisporites bulliferus Richardson and Mc Gregor, 1986 


\section{Acknowledgments}

We would like to thank the two anonymous reviewers who have made valuable improvements to the realisation of this manuscript. We thank M. Jones for the processing of the samples and Enda Breen for the reviewing of the English. PS is FSR-FNRS Senior Research Associate. EP, MB, SB, and RR are grateful to CNPq, FAPERJ, Finep and FUSP for the research fellowship (MB) and for financial support in the scope of the Project "Rede GASBRAS".

\section{Conflict of interest}

The authors declare that they have no known competing fina $x_{1}>1 \mathrm{ir}$. terests or personal relationships that could have appeared to influence the work reported in th. - baper.

P. Steemans

\section{References}

Aguiar, G.A. 1971. Revisão geológic` da bacıa paleozóica do Maranhão. An. XXV Cong. Brasil. Geol. Soc. Brasil., São Paulo Prc zil, 3, 113-122.

Almeida, F.F.M., Carneiro, C.P ^ 2004. Inundações marinhas fanerozóicas no Brasil e recursos minerais associados. In Mantsesso-Neto, V., Bartorelli, A., Carneiro, C.D.R., BritoNeves, B.B. (eds). Gє lo ‘ia r o continente sul-americano: evolução da obra de Fernando Flávio Marques de Almi: da. Beca, São Paulo, Brazil, 3, 43-58.

Andrade, C.L.N., Cardoso, T.R.M., Santos, R.R., Dino, R., Machado A.J., 2020. Organic facies and palynology from the middle to late Devonian of the Pimenteiras Formation, Parnaíba Basin, Brazil. J. S. Am. Earth. Sci., 99, https://doi.org/10.1016/j.jsames.2019.102481 Andrade, S.M., Daemon, R.F., 1974. Litoestratigrafia e bioestratigrafia do flanco sudoeste da Bahia do Parnaíba (Devoniano e Carbonífero). An. $28^{\circ}$ Congr. Brasil. Geol., Porto Alegre, 2, 129-137. 
Bär, P., Riegel, W., 1974. Les Microflores des séries paléozoïques du Ghana (Afrique occidentale) et leurs relations paléofloristiques. Sc. Géol. Bull., 27 (1-2), 39-58.

Becker, R.T. 2007. International union of Geological Sciences, commission on stratigraphy. Subcommission on Devonian Stratigraphy, Newsletter, 22, 111p.

Becker, R.T., Königshof, P., Brett, C.E., 2016. Devonian climate, sea level and evolutionary events: an introduction, in: Becker, R.T., Königshof, P., Brett, C.E. (Eds.), Devonian climate, sea level and evolutionary events. Geological Society, London, Special Publications, 423, 110.

Beurlen, K., 1965. Observações no Devoniano do Estado d s íauí. Anais Acad. Brasil. Ciên., Rio de Janeiro, 37, 61-75.

Bond, D.P.G., Wignall, P.B., 2008. The role of sea-leve, hange and marine anoxia in the Frasnian-Famennian (Late Devonian) mass ex ‘iı tir n. Palaeogeogr. Palaeoclimatol. Palaeoecol., 263(3-4), 107-118.

Bosetti, E.P., Grahn, Y., Horodyski, R.^ Mendlowicz Mauller, P., Breuer, P., Zabini, C., 2011. An earliest Givetian "Lillip» ${ }^{+}$E $f_{e}$ ¿t” in the Paraná Basin, and the collapse of the Malvinokaffric shelly fauna. F: laeontol. Z., 85, 49-65.

Breuer, P., Grahn, Y., 2011. i Mir.dle Devonian spore stratigraphy in the eastern outcrop belt of the Parnaíba Basin, noı ‘'eastern Brazil. Rev. Esp. Micropal., 43, 19-38.

Breuer, P., Steemans, P., 2013. Devonian spore assemblages from northwestern Gondwana: Taxonomy and biostratigraphy. Spec. Pap. Paleontol., 89, 1-163.

Brito, I.M., 1967. Silurian and Devonian Acritarcha from Maranhão Basin, Brazil. Micropal., $13(4), 473-482$.

Brito, I.M., 1971. Contribuição ao conhecimento dos microfósseis silurianos e devonianos da Bacia do Maranhão. V - Acritarcha Herkomorphitae e Prismatomorphitae. An. Acad. Brasil. Ci., 43 (Suplemento), 201-208. 
Brito, I.M., 1976. Contribuição ao conhecimento dos microfósseis Devonianos de

Pernambuco. III. Aguns Acritarcha comuns aos do Devoniano do Saara. An. Acad. Brasil. Ci., $48(4), 747-756$.

Brito, I.M., Quadros, L.P., 1984. Novas ocorrências de Acritarchae no Devoniano da Bacia do Parnaiba. Bol. IG-USP, 15, 15-19.

Burjack, M.I.A., Oliveira, S. F. 1989. Contribucão ao conhecimento morfológico e sistemático do Género Maranhites Brito. In Paleobotânica e Palinologia na América do Sul 1987, Bol. IG-USP, 7, 45-67.

Burjack, M.I.A., Loboziak, S., Streel, M., 1987. Quelques iU. nees nouvelles sur les miospores dévoniennes du bassin du Paraná (Brésil), Sr C‘óol., 40, 381-391.

Caputo, M.V., 1984. Stratigraphy, tectonics, palcou:matology, and paleogeography of northern basins of Brazil. - Unpub. Ph.D Thesi s, ' ini v. of California, Santa Barbara, 586 p. Caputo, M.V., Crowell, J.C., 1985. M. rra . Ion of glacial centers across Gondwana during Paleozoic Era. Geol. Soc. America Buı. 96, 1020-1036.

Cioccari, G.M. and Mizusaki, ^.N. F, 2019. Sistemas petrolíferos atípicos nas Bacias Paleozoicas Brasileiras - Uma : eviscio. Geociências, 38, 367-390.

Collinson, C., Scott, A.I., 1C58. Chitinozoan faunule of the Devonian Cedar Valley Formation. Illinois Staı (sculogical Survey. Circular 247, 1-34.

Creaney, S., Passey, Q.R., 1993. Recurring patterns of total organic carbon and source rock quality within a sequence stratigraphic framework. AAPG Bull., 77, 386-401.

Cruz, N.M.C., Quadros, L.P., 1985. Sommerochitina langei, um novo fóssil-guia do Devoniano Superior da Bacia do Parnaíba. In: Campos, D.A.; Ferreira, C.S.; Brito, I.M., Viana, C.F. (eds.). Coletânea de trabalhos paleontológicos; trabalhos apresentados no VIII Congresso Brasileiro de Paleontologia—1983. Brasília, DNPM, 289-293. 
Daemon, R.F., 1964. Estratigrafia preliminar dos Chitinozoa da Bacia do Maranhão.

Salvador, PETROBRAS/RPBA (Unpubl. report.), 1-18.

Daemon, R.F., 1974. Palinomorfos-guias do Devoniano Superior e Carbonífero Inferior das bacias do Amazonas e Parnaíba. An. Acad. Bras. de Ciênc., 46, 549-587.

Daemon, R. F., 1976. Correlação bioestratigráfica entre os sedimentos do Siluriano, Devoniano e Carbonífero Inferior das bacias do Amazonas, Parnaíba e Paraná. Anais $29^{\circ}$ Congres. Brasil. Geol. Soc. Bras. Geol., Ouro Preto., 2, 189-194.

Daemon, R.F., Contreiras, C.J.A., 1971. Zoneamento palinológiro ‘`ج Bacia do Amazonas. Anais do XXV Congr. Brasil. Geol. Soc. Bras. Geol., São ``au'?, Brazil, 3, 79-88.

Dino, R., Melo, H.G., Grahn, Y., 1996. Devonian palynol. orphs from the western border of the Parnaiba Basin, Tocantins valley region, northern Bı $:$ zil, Program and Abstract. 9th Internat. Palynol. Cong. Houston, 34.

Espitalie, J., Laporte, J.L., Madec, M., N. ro ıis, F., Leplat, P., Paulet, J., Boutefeu, A., 1977. Méthode rapide de caracterisation des 1 - hes mères, de leur potentiel pétrolier et de leur degré d'evolution, Rev. Inst. Fr. Pet., 32 73-17.

Góes, A.M.O, Feijó, F.J., 1994. Bacia do Parnaíba. Bol. Geociên.Petrobras, 8, 58-60.

Grahn, Y., Melo, J.H.G., 20u: Middle and Late Devonian Chitinozoa and biostratigraphy of the Parnaíba and Jatoba Qasins, northeastern Brazil. Palaeontogr. Abt. B, 272, 1-68.

Grahn, Y., Loboziak, S., Melo, J.H.G., 2001. Integrated miospore-chitinozoan biozonation of the Parnaíba Basin and its correlation with Petrobras (Müller 1962) Silurian-Lower Carboniferous palynozones. In: Melo J.H.G., Terra G.J.S. (eds.) Correlação de sequências paleozoicas sul-americanas. Ciência-Técnica-Petróleo. Seção: Exploração de Petróleo, 20, 8189. 
Grahn, Y., Melo, J.H.G., Loboziak, S., 2006. Integrated middle and late Devonian miospore and chitinozoan zonation of the Parnaíba Basin, Brazil: An Update. Rev. Brasil. Paleont. 9, 283-294.

Haq, B. U., Schutter, S.R., 2008. A Chronology of Palaeozoic Sea-Level Changes. Science, 322(5898), 64-68.

Higgs, K., Prestianni, C., Streel, M., Thorez, J., 2013. High resolution miospore stratigraphy of the Upper Famennian of eastern Belgium, and correlation with the conodont zonation. Geol. Belg., 16(1-2), 84-94.

Jardiné, S., 1972. Microplancton (Acritarches) et limites st ati_raphiques du Silurien terminal au Dévonien supérieur. C.R. Septième Congr. Int. Stratiog. Géol. Carbon., Krefeld. (Aug. 1971), 1, 313-323.

Jardiné, S., Combaz, A., Magloire, L., Penigue1, ‘ J Jachey, G., 1974. Distribution stratigraphique des Acritarches dans le p. 'ér zoïque du Sahara algérien. Rev. Palaeobot. Palynol, 18, 99-129.

Jones, R.W., 1987. Organic Facies In. Prooks, J., Welte, D. (Eds.), Advances in Petroleum Geochemistry. Acad. Press., Li ndon, UK., 2, 1-90.

Kegel, W. 1953. Contribuica n ra o estudo do Devoniano da bacia do Parnaíba. Bol. Div. Geol. e Min. DNPM., 1 $^{1} 1,1-48$

Lange, F.W., 1952. Quitinozoários de Folhelho Barreirinha, Devoniano de Paraná. Dusenia, 3, 373-386.

Lange, F.W. 1967. Biostratigraphic subdivision and correlation of the Devonian in the Paraná Basin. Bol. Parana. Geociên, 21/22, 63-98.

Lange, F.W., Petri, S. 1967. The Devonian of the Paraná Basin. Bol. Paranaense Geociên., 21/22, 5-55. 
Lanzoni, E., Magloire, L., 1969. Associations palynologiques et leurs applications stratigraphiques dans le Dévonien supérieur et Carbonifère inférieur du Grand Erg occidental (Sahara algérien). Rev. Inst. fr. Pétr. Ann. Comb. Liq., XXIV (4), 441-469.

Le Hérissé, A., 2001. Evolution of Devonian phytoplanktonic assemblages in the upper Ererê Formation and Curuá Group (Barreirinha and lower Curiri formations), Tapajós River area, Amazon Basin, northern Brazil. In: Melo J.H.G., Terra G.J.S. (eds.). Correlação de sequências paleozoicas sul-americanas. Ciência-Técnica-Petróleo. Seção: Exploração de Petróleo, 20, 117-124.

Lima, E.C., Leite, J.F. 1978. Projeto Estudo Global dos Re_uı os Minerais da Bacia Sedimentar do Parnaíba; integraçãomgeológico-mc:qlogenética, relatório final da etapa III. Internal report, CPRM-Companhia de Pesquisa d k nursos Minerais, Recife, PE, Brazil, Vol. 1-2.

Loboziak, S., Caputo, M.V., Melo, J.H.C 2 J00. Middle Devonian-Tournaisian miospore biostratigraphy in the southwestern ouı op belt of the Parnaíba Basin, North-Central Brazil. Rev. Micropal., 43, 301-318.

Loboziak, S., Streel, M., Burja''r, M.A.I., 1988. Miospores du Dévonien moyen et supérieur du bassin du Parana, Brésil: ‘ṽómatique et stratigraphie. / Middle-Upper Devonian miospores from the Paı na vasin: Systematics and Stratigraphy. Sc. Géol., Bull. Mém., 41(34), 351-377.

Loboziak, S., Steemans, P., Streel, M., Vachard, D., 1992a. Biostratigraphie par miospores du Dévonien inférieur à supérieur du sondage MG-1 (Bassin d'Hammadah, Tunisie).

Comparaison avec les données des faunes. Rev. Palaeobot. Palynol., 74, 193-205.

Loboziak, S., Streel, M., Caputo, M.V., Melo, J.H.G., 1992b. Middle Devonian to Lower Carboniferous miospores stratigraphy in the central Parnaiba Basin (Brazil). Ann. Soc. Géol. Belg., 115, 215-226. 
Loboziak, S., Melo, H.G., Quadros, L.P., Daemon, R.F., 1994. Devonian-Dinantian miospore biostratigraphy of the Solimões and Parnaíba Basins (with some considerations on the Devonian of the Paraná Basin). Petrobras/Cenpes, Rio de Janeiro, Technical Report 2.

Loboziak, S., Melo, J.H.G., 2002. Devonian miospore successions of Western Gondwana: Update and correlation with Southern Euramerican miospore zones. Rev. Palaeobot. Palynol., $121,133-148$.

Lüning, S., Wendt, J., Belka, Z., Kaufmann, B. 2004. Temporal-spatial reconstruction of the early Frasnian (Late Devonian) anoxia in NW Africa: New field da? from the Ahnet Basin (Algeria). Sedim. Geol., 163, 237-264.

Melo, J.H.G. 1988. The Malvinokaffric realm in the Devı nian of Brazil. - In: McMillan, N.J., Embry, A. F., Glass, D.J. (eds.). Devonian of the W, orld. Canadian Soc. Petrol. Geol. Mem., 1 (14), 669-703

Melo, J.H.G., 2005. Selected Devonian p ply ıological biohorizons in Brazilian Palaeozoic basins: State-of-the-art. In: Gondwana :'II, Mendoza, Academia Nacional de Ciencias; Cordoba, Argentina, Abstracts, 240

Melo, J.H.G., Loboziak, S., 20:3. Levonian-Early Carboniferous miospore biostratigraphy of the Amazon Basin, northern Pro zil. Rev. Palaeobot. Palynol., 124, 131-202.

Milani, E.J., Thomaz F.'ho, A., 2000. Sedimentary basins of South America. In: Cordani, U.G.; Milani, E.J., Thomas Filho, A., Campos, D.A. (Eds). Tectonic evolution of South America. Rio de Janeiro: International Geological Congress, 31, pp. 389-450.

Miranda, F.S, Vettorazzi, A.L., Cunha, P.R.C., Aragão, F.B., Michelon, D., Caldeira, J.L., Porsche, E., Martins, C., Ribeiro, R.B., Vilela, A.F., Corrêa, J.R., Silveira, L.S., Andreola, K., 2018. A Typical igneous-sedimentary petroleum system of the Parnaíba Basin, Brazil: Seismic, well logs and cores. In Daly, M.C., Fuck, R.A., Julià, J., Macdonald, D.I.M., Watts, 
A.B. (Eds.). Cratonic Basin Formation: A Case Study of the Parnaíba Basin of Brazil. Geol.

Soc., Lond., Sp. Pub, 472, 341-360.

Molyneux, S.G., Le Hérissé, A., Wicander, R., 1996. Palaeozoic phytoplankton. In:

Jansonius, J., McGregor, D.C. (eds.). Palynology: Principles and applications. Salt Lake City, AASP Found, 2, 493-529.

Müller, H., 1962. Report on palynological results of samples examined from wells in Maranhão. Salvador, PETROBRAS/RPBA (Unpubl. report.), 44 p.

Myers, K.J., 2004. Organic-rich facies and hydrocarbon source roci- In: Emery, D., Myers, K.J. (Eds.). Sequence Stratigraphy, Blackwell Science, Ox on' L38 - 257.

Noetinger, S., Di Pasquo, M.M., 2011. Devonian palynnlu rical assemblages from the San

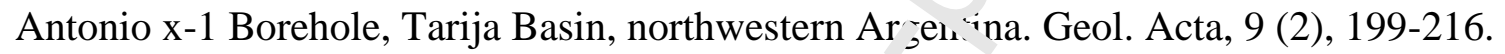

Obukhovskaya, T., 2000. Miospores of the Giv ei ,n Frasnian boundary deposits in Belarus. Acta Palaeobo., 40(1), 17-23

Oliveira, S.F., 1997. Palinologia da seq`ância devoniana da Bacia do Paraná no Brasil, Paraguai e Uruguai: Implicações hincı ^r oestratigráficas, paleoambientais e paleogeográficas. Ph.D. Thesis, Universidade de :'ão เ aulo, Brazil.

Oliveira, S.F., Burjack, M.I.r- 996. Petrovina connata gen. n., sp. n. provavelmente relacionado à Chloroph „`a, ua Formação Ponta Grossa (Neodevoniano), Bacia do Paraná, MT, Brasil. Revista Universidade de Guarulhos. Sér. Geociên., 1 (3), 46-50.

Oliveira, S. F., Burjack, M.I.A., 1997. Nova espécie de paleomicroplâncton de parede orgânica (acritarco) da Formação Ponta Grossa (Frasniano) Bacia do Paraná, MT, Brasil, Revista Universidade de Garulhos, Sér. Geociên., 2 (67), 86-91.

Ottone, E.G., 1996. Devonian palynomorphs from the Los Monos Formation, Tarija Basin, Argentina. Palynology, 20, 105-155. 
Paris, F., Winchester-Seeto, T., Boumendjel, K., Grahn, Y., 2000. Toward a global biozonation of Devonian chitinozoans. Cour. Forschung. Senck., 220, 39-55.

Pereira, E., Carneiro, C.R., Bergamaschi, S., Almeida, F.F.M., 2012. Evolução das Sinéclises Paleozoicas: Províncias Solimões, Amazonas, Parnaíba e Paraná. In: Hasui, Y., Carneiro, C.D.R., Almeida, F.F.M., Bartorelli, A. (Eds.), Geologia do Brasil. Beca, Sao Paulo, Brazil, pp. 374-394.

Plummer, F.B. 1948. Estados do Maranhão e Piauí. Unoub. Internal report, Conselho Nac.Petról. Rio de Janeiro, Brasil, Relatório de 1946, 87-134.

Posamentier, H.W., Allen, G.P., 1999. Siliciclastic sequenre s ratıgraphy - Concepts and applications. SEPM Concepts in Sedimentology and Palec ntology, 7, 210.

Quadros, L.P., 1980. Ocorrência de palinomorfos em sen 'mentos paleozóicos da Bacia de Jatobá (Pernambuco). Rev. Brasil. Geociên., 1n, ‘’-'2.

Quadros, L.P., 1982. Distribuição bioest, `tir ,ráfica dos Chitinozoa e Acritarchae na Bacia do Parnaíba. Ciência Técnica-Petróleo. Seç ̃̃o: Explor. Petról., 12, 1-76.

Quadros, L.P., 1996. Pseudomaranhit' $\cdot$ novo gênero de acritarco do Devoniano superior da Bacia do Amazonas. Anais XX XIX Congresso Brasileiro de Geologia, Soc. Bras. Geol. Salvador de Bahia, 1996, Paı nr iologia, 2, 281-284.

Quadros, L.P., 1999. Ne 'os acritarcos do Devoniano Superior da Bacia do Amazonas. Acta Geol. Leopol., 23 (49), 15-27.

Rodrigues, R., 1995. A Geoquímica orgânica da bacia do Parnaíba. Ph.D. Thesis, Porto Alegre, Rio Grande do Sul, Brasil. Universidade Federal do Rio Grande do Sul.

Rodrigues, R., 2001. Caracterização geoquímica do evento anóxico/disóxico do Frasniano nas bacias do Amazonas e Parnaíba. In: J.H.G. Melo and G.J.S. Terra (eds.). Correlação de sequências paleozoicas sul-americanas. Ciênca-Técnica-Petróleo. Seção: Expl. Petról., 20, 109-116. 
Rodrigues, R., 2005. Chemostratigraphy. In: Koutsoukos, E. (Ed). Applied Stratigraphy. Springer, New York, 165-178.

Rodrigues, R., Loboziak, S., Melo, J.H.G., Alves, D.B., 1995. Geochemical characterization and miospore biochonostratrigraphy of the Frasnian anoxic event in the Parnaíba Basin, Northeast Brazil. Bull. Centres Rech. Explo. - Prod. Elf Aquitaine, 19 (2), 319-327.

Rodrigues, R., Pereira, E., Bergamaschi, S., 2012. Rochas Geradoras Devonianas e Permianas nas Bacias Paleozóicas Brasileiras, In: Anais da Rio Oil \& Gas Expo and Conference 2012, Instituto Brasileiro de Petróleo, Gás e Biocombustíveis - IBP, Pio `` Janeiro, Brasil. Sommer, F.W., Van Boekel, N.M., 1964. Quitinozoários d u L `voniano de Goiás. An. Acad. Brasil. Ciên., 36, 423-431.

Small, H.L. 1914. Geologia e supprimento d'agua surte "ənea no Piauhy e parte do Ceará. Inspec. de Obras Contra as Seccas. Serie I.D. Ce. . J2, 1-186.

Souza, M.S.P., Mauller, P.M., Cardoso, ’ R , Rodrigues, R., Pereira, E., 2013. Caracterização Geoquímica e Bioestratigráfica das Sup`rfícies de Inundação Marinha da Seção MesoNeodevoniana, na Região de Dom 4q '⿳亠丷厂 $\mathrm{o}$ (MT), Noroeste da Bacia do Paraná, Brasil. Anuário do Instituto de Geociê. cias (UFRJ. Impresso), 36(1), 15-25.

Streel, M., 2009. Upper Deve nir.n miospore and conodont zone correlation in western Europe. In: Königshof, P. (Ed.), Tevonian change: Case studies in palaeogeography and palaeoecology. Geol. Soc., Lond., Sp. Pub., 314, 163-176.

Streel, M., Higgs, K.T., Loboziak, S., Riegel, W., Steemans, P., 1987. Spore stratigraphy and correlation with faunas and floras in the type marine Devonian of the Ardenno-Rhenish regions. Rev. Palaeobot. Palynol., 50, 211-229.

Streel, M., Caputo, M.V., Loboziak, S., Melo, J.H.G., 2000a. Late Frasnian-Famennian climates based on palynomorph analyses and the question of the Late Devonian glaciations. Earth-Sc. Rev., 52(1), 121-173 
Streel, M., Loboziak, S., Steemans, P., Bultynck, P., 2000b. Devonian miospore stratigraphy and correlation with the global stratotype sections and points. In: Bultynck, P. (Ed.), Subcommission on Devonian Stratigraphy. Cour. Forsch.-Inst. Senckenberg, 220, 9-23.

Streel, M., Boulvain, F., Dusar, M., Loboziak, S., Steemans, P., submitted. Updating Frasnian miospore zonation from the Boulonnais (Northern France) and comparison with new data from the Upper Palaeozoic cover on the Brabant Massif (Western Belgium). Geologica Belgica.

Sutton, S.J., Ethridge, F.G., Almon, W.R., Dawson, W.C., Ed var 's, K.K., 2004. Textural and sequence-stratigraphy controls on sealing capacity of Low $r$ an 1 Upper Cretaceous shales, Denver basin, Colorado. AAPG Bull., 88, 1185-1206

Telnova, O.P., 2008. Palynological characterization of Givetian-Frasnian deposits in the reference Borehole section 1-Balneologichesk: va (southern Timan). Stratigraphy and Geological Correlation, 16(2), 143-161.

Telnova, O., Soboleva, M., Sobolev, ‥ _ 19. Upper Devonian Cristatisporites deliquescens Palynozone and its Correlation (Tımı n-North Urals Region). Filodiritto Editore -Proceedings, 253-261.

Trindade, V.S.F., Carval`^u, M.A., 2018. Paleoenvironment reconstruction of Parnaíba Basin (north, Brazil) using indic tor species analysis (IndVal) of Devonian microphytoplankton. Mar. Micropaleont., 140, 69-80.

Vanguestaine, M., Declairfayt, T., Rouhart, A., Smeesters, A., 1983. Zonation par acritarches du Frasnien supérieur-Famennien inférieur dans les bassins de Dinant, Namur, Herve et Campine (Dévonien supérieur de Belgique). Ann. Soc. Géol. Belg., 106, 121-171. Zambrano, E.R.N.; Oliveira, O.M.C.; Severiano Ribeiro, H.J.P., 2017. Caracterização geoquímica com indícios paleoambientais de folhelhos da Formação Pimenteiras, estado do Tocantins, Bacia do Parnaíba, Brasil. Rev. Inst. Geoc. USP, 17, 67-78. 
Zwan, C.J. van der, 1980. Aspects of late devonian and early carboniferous palynology of southern Ireland. II. The Auroraspora macra morphon. Rev. Palalaebot. Palynol., 30, 133-155.

Fig. 1: Location map of the studied sites.

Fig. 2: Sedimentological compound section of sites 10, 12 and 11, and the correspondent TOC contents of the Pimenteiras Formation in the sites.

Fig. 3: Sedimentological section of site 35, and the correspondent TOC contents of the Pimenteiras Formation in the site.

Fig. 4: Sedimentological section of site 37, and the corresp ond nt TOC contents of the Pimenteiras Formation in the site.

Fig. 5: Miospore biostratigraphic scale from the Old Red sandstone Continent (A), correlated with Brazil (B). Most probable age of the ana', sea samples (C). Extension of the most diagnostic species of Acritarchs and other . icroalgal remains recognised in the material studied, age and correlation of the int-"vai represented.

Fig. 6: Miospore biostratigraphic sci'a trom the Old Red Sandstone Continent (A), correlated with Brazil (B). Based on the hic tratigraphic range observed in the Boulonais sections, France (Streel et al., in p epc raıon) of some important species. Most probable age of the analysed samples (C)

Tbl. 1: Pyrolysis and Total Organic Carbon content (TOC) data from Sites 10, 11, 12 and 35 using Rock-Eval Pyrolysis method.

\begin{tabular}{|c|c|c|c|c|c|c|c|c|c|c|c|c|c|c|c|c|}
\hline $\begin{array}{c}\text { Profundida } \\
\text { de }\end{array}$ & $\begin{array}{l}\text { Bar } \\
\text { quin } \\
\text { ha }\end{array}$ & $\begin{array}{c}\text { Barq. } \\
+ \text { +Amo } \\
\text { st. }\end{array}$ & $\begin{array}{c}\text { De } \\
\text { sca } \\
\text { r. }\end{array}$ & $\begin{array}{l}P \\
\text { es } \\
0\end{array}$ & $\begin{array}{l}R \\
. I\end{array}$ & $\begin{array}{l}\mathrm{C} \\
\mathrm{O} \\
\mathrm{T} \\
\%\end{array}$ & $\begin{array}{l}\mathrm{S} \\
\%\end{array}$ & & $\begin{array}{l}\text { Mas } \\
\text { sa } \\
\text { (mg) }\end{array}$ & $\begin{array}{c}\text { S1 } \\
\text { (mg } \\
\text { /g) }\end{array}$ & $\begin{array}{l}\text { S2( } \\
\mathrm{mg} \\
\text { /g) }\end{array}$ & $\begin{array}{c}\text { S3 } \\
\text { (mg } \\
\text { /g) }\end{array}$ & $\begin{array}{l}\mathrm{Tm} \\
\left.\mathrm{ax}\right|^{\circ} \\
\mathrm{C})\end{array}$ & $\begin{array}{l}\mathrm{C} \\
\mathrm{O} \\
\mathrm{T} \\
\%\end{array}$ & $\begin{array}{l}\mathrm{I} \\
\mathrm{H}\end{array}$ & \\
\hline AMT 01 & $\begin{array}{c}37.0 \\
49\end{array}$ & $\begin{array}{c}37.30 \\
2\end{array}$ & $\begin{array}{c}37 . \\
29 \\
7\end{array}$ & $\begin{array}{l}0 . \\
2 \\
5 \\
3\end{array}$ & $\begin{array}{l}9 \\
8\end{array}$ & $\begin{array}{l}1 . \\
40\end{array}$ & $\begin{array}{l}0 . \\
1 \\
7\end{array}$ & $\begin{array}{c}\text { AM- } \\
1\end{array}$ & $\begin{array}{c}63.0 \\
2\end{array}$ & $\begin{array}{c}0.0 \\
5\end{array}$ & $\begin{array}{c}4.7 \\
5\end{array}$ & 0.2 & $\begin{array}{c}42 \\
5\end{array}$ & $\begin{array}{l}1 . \\
40\end{array}$ & $\begin{array}{l}3 \\
3 \\
9\end{array}$ & $\begin{array}{l}1 \\
4\end{array}$ \\
\hline
\end{tabular}




\begin{tabular}{|c|c|c|c|c|c|c|c|c|c|c|c|c|c|c|c|c|}
\hline AMT $01 \mathrm{~A}$ & $\begin{array}{c}38.2 \\
37\end{array}$ & $\begin{array}{c}38.48 \\
5\end{array}$ & $\begin{array}{c}38 . \\
48 \\
1\end{array}$ & $\begin{array}{l}0 . \\
2 \\
4 \\
8\end{array}$ & $\begin{array}{l}9 \\
8\end{array}$ & $\begin{array}{l}1 . \\
29\end{array}$ & $\begin{array}{c}0 . \\
1 \\
0\end{array}$ & $\begin{array}{c}1- \\
\text { TOA }\end{array}$ & $\begin{array}{c}54.6 \\
9\end{array}$ & $\begin{array}{c}0.0 \\
7\end{array}$ & $\begin{array}{c}4.4 \\
6\end{array}$ & $\begin{array}{c}0.1 \\
6\end{array}$ & $\begin{array}{c}43 \\
1\end{array}$ & $\begin{array}{l}1 . \\
29\end{array}$ & $\begin{array}{l}3 \\
4 \\
6\end{array}$ & $\begin{array}{l}1 \\
2\end{array}$ \\
\hline AMT 02 & $\begin{array}{c}37.9 \\
07\end{array}$ & $\begin{array}{c}38.16 \\
1\end{array}$ & $\begin{array}{c}38 . \\
15 \\
8\end{array}$ & $\begin{array}{l}0 . \\
2 \\
5 \\
4\end{array}$ & $\begin{array}{l}9 \\
9\end{array}$ & $\begin{array}{l}1 . \\
47\end{array}$ & $\begin{array}{l}0 . \\
0 \\
5\end{array}$ & 2-TO & $\begin{array}{c}58.9 \\
9 \\
\end{array}$ & $\begin{array}{c}0.0 \\
7\end{array}$ & $\begin{array}{c}5.1 \\
1\end{array}$ & 0.4 & $\begin{array}{c}42 \\
6 \\
\end{array}$ & $\begin{array}{c}1 . \\
47 \\
\end{array}$ & $\begin{array}{l}3 \\
4 \\
8\end{array}$ & $\begin{array}{l}2 \\
7 \\
\end{array}$ \\
\hline AMT 03 & $\begin{array}{c}36.9 \\
53 \\
\end{array}$ & $\begin{array}{c}37.20 \\
6 \\
\end{array}$ & $\begin{array}{c}37 . \\
20 \\
2\end{array}$ & $\begin{array}{l}0 . \\
2 \\
5 \\
3\end{array}$ & $\begin{array}{l}9 \\
8\end{array}$ & $\begin{array}{l}1 . \\
22\end{array}$ & $\begin{array}{l}0 . \\
0 \\
5\end{array}$ & 3-TO & $\begin{array}{c}56.6 \\
8 \\
\end{array}$ & $\begin{array}{c}0.0 \\
7 \\
\end{array}$ & $\begin{array}{c}3.7 \\
9 \\
\end{array}$ & $\begin{array}{c}0.2 \\
4 \\
\end{array}$ & $\begin{array}{c}42 \\
6 \\
\end{array}$ & $\begin{array}{c}1 . \\
22 \\
\end{array}$ & $\begin{array}{l}3 \\
1 \\
1\end{array}$ & $\begin{array}{l}2 \\
0 \\
\end{array}$ \\
\hline AMT 04 & $\begin{array}{c}38.0 \\
79\end{array}$ & $\begin{array}{c}38.33 \\
1\end{array}$ & $\begin{array}{c}38 . \\
32 \\
9\end{array}$ & $\begin{array}{l}0 . \\
2 \\
5 \\
2\end{array}$ & $\begin{array}{l}9 \\
9\end{array}$ & $\begin{array}{l}1 . \\
24\end{array}$ & $\begin{array}{l}0 . \\
0 \\
5\end{array}$ & $4 \mathrm{TO}$ & 51.7 & $\begin{array}{c}0.0 \\
b\end{array}$ & $\begin{array}{c}4.4 \\
1\end{array}$ & $\begin{array}{c}0.1 \\
4\end{array}$ & $\begin{array}{c}42 \\
8\end{array}$ & $\begin{array}{l}1 . \\
24\end{array}$ & $\begin{array}{l}3 \\
5 \\
6\end{array}$ & $\begin{array}{l}1 \\
1\end{array}$ \\
\hline AMT 05 & $\begin{array}{c}38.4 \\
21\end{array}$ & $\begin{array}{c}38.67 \\
0\end{array}$ & $\begin{array}{c}38 . \\
65 \\
6\end{array}$ & $\begin{array}{l}0 . \\
2 \\
4 \\
9\end{array}$ & $\begin{array}{l}9 \\
4 \\
\end{array}$ & $\begin{array}{l}1 . \\
16\end{array}$ & $\begin{array}{c}0 . \\
1 \\
1\end{array}$ & $5 \mathrm{TO}$ & 735 & ?.u & $\begin{array}{c}1.6 \\
5\end{array}$ & $\begin{array}{c}0.1 \\
5\end{array}$ & $\begin{array}{c}43 \\
0 \\
\end{array}$ & $\begin{array}{c}1 . \\
16 \\
\end{array}$ & $\begin{array}{l}1 \\
4 \\
2\end{array}$ & $\begin{array}{l}1 \\
3\end{array}$ \\
\hline AMT $05 \mathrm{~A}$ & $\begin{array}{c}37.1 \\
16 \\
\end{array}$ & $\begin{array}{c}37.37 \\
0\end{array}$ & $\begin{array}{c}37 . \\
36 \\
1\end{array}$ & $\begin{array}{l}0 . \\
2 \\
5 \\
4\end{array}$ & $\begin{array}{l}9 \\
6\end{array}$ & $\begin{array}{l}1 . \\
10\end{array}$ & $\begin{array}{l}0 . \\
0 \\
7\end{array}$ & $\begin{array}{l}5 \mathrm{~A} \\
\text { TO }\end{array}$ & $\begin{array}{c}56 / \\
4\end{array}$ & $\begin{array}{c}0.0 \\
2\end{array}$ & $\begin{array}{c}0.9 \\
1\end{array}$ & $\begin{array}{c}0.2 \\
9\end{array}$ & $\begin{array}{c}43 \\
0\end{array}$ & $\begin{array}{l}1 . \\
1\end{array}$ & $\begin{array}{l}8 \\
3\end{array}$ & $\begin{array}{l}2 \\
6\end{array}$ \\
\hline AMT 06 & $\begin{array}{c}37.7 \\
36\end{array}$ & $\begin{array}{c}37.98 \\
4\end{array}$ & $\begin{array}{c}37 . \\
97 \\
3\end{array}$ & $\begin{array}{l}0 . \\
2 \\
4 \\
8\end{array}$ & $\begin{array}{l}9 \\
6\end{array}$ & $\begin{array}{l}0 . \\
7 i\end{array}$ & $\begin{array}{l}0 . \\
\vdots \\
1\end{array}$ & & & & & & & & & \\
\hline AMT 07 & $\begin{array}{c}37.2 \\
97\end{array}$ & $\begin{array}{c}37.54 \\
7\end{array}$ & $\begin{array}{c}37 . \\
52 \\
6\end{array}$ & $\begin{array}{l}0 . \\
2 \\
5 \\
0\end{array}$ & $\begin{array}{l}9 \\
2\end{array}$ & ? & $\begin{array}{l}0 . \\
0 \\
5\end{array}$ & & & & & & & & & \\
\hline $\begin{array}{c}\text { AMT } \\
07 \text { REP }\end{array}$ & $\begin{array}{c}37.3 \\
28 \\
\end{array}$ & $\begin{array}{c}37.57 \\
8\end{array}$ & $\begin{array}{c}37 . \\
56 \\
2\end{array}$ & $\begin{array}{l}0 . \\
? \\
0 \\
0\end{array}$ & $\begin{array}{l}9 \\
4\end{array}$ & $\begin{array}{l}0 . \\
54\end{array}$ & $\begin{array}{l}0 . \\
0 \\
7\end{array}$ & & & & & & & & & \\
\hline АMT 08 & $\begin{array}{c}37.7 \\
06\end{array}$ & $\begin{array}{c}37.95 \\
7\end{array}$ & $\begin{array}{c}37 . \\
3: \\
;\end{array}$ & $\begin{array}{l}2 \\
5 \\
1\end{array}$ & $\begin{array}{l}9 \\
5\end{array}$ & $\begin{array}{l}0 . \\
98\end{array}$ & $\begin{array}{c}0 . \\
1 \\
0\end{array}$ & $8 \mathrm{TO}$ & $\begin{array}{c}56.2 \\
8\end{array}$ & $\begin{array}{c}0.0 \\
3\end{array}$ & $\begin{array}{c}0.6 \\
9\end{array}$ & $\begin{array}{c}0.2 \\
2\end{array}$ & $\begin{array}{c}42 \\
9\end{array}$ & $\begin{array}{l}0 . \\
98\end{array}$ & $\begin{array}{l}7 \\
0\end{array}$ & $\begin{array}{l}2 \\
2\end{array}$ \\
\hline АMT 09 & $\begin{array}{c}38.0 \\
05\end{array}$ & $\begin{array}{c}38.25 \\
6\end{array}$ & $\begin{array}{c}38 . \\
24 \\
7\end{array}$ & $\begin{array}{l}0 . \\
2 \\
5 \\
1\end{array}$ & $\begin{array}{l}9 \\
6\end{array}$ & $\begin{array}{l}2 . \\
21\end{array}$ & $\begin{array}{l}2 . \\
0 \\
2\end{array}$ & 9 TO & 67.1 & $\begin{array}{c}0.0 \\
5\end{array}$ & 3.3 & $\begin{array}{c}0.1 \\
7\end{array}$ & $\begin{array}{c}42 \\
2\end{array}$ & $\begin{array}{c}2 . \\
21\end{array}$ & $\begin{array}{l}1 \\
4 \\
9\end{array}$ & 8 \\
\hline AMT 10 & $\begin{array}{c}38.5 \\
67\end{array}$ & $\begin{array}{c}38.81 \\
7\end{array}$ & $\begin{array}{c}38 . \\
81 \\
0\end{array}$ & $\begin{array}{l}0 . \\
2 \\
5 \\
0\end{array}$ & $\begin{array}{l}9 \\
7\end{array}$ & $\begin{array}{l}2 . \\
01\end{array}$ & $\begin{array}{l}0 . \\
4 \\
6\end{array}$ & $\begin{array}{l}10 \\
\text { TO }\end{array}$ & $\begin{array}{c}48.2 \\
4\end{array}$ & $\begin{array}{c}0.0 \\
6\end{array}$ & $\begin{array}{c}4.6 \\
4\end{array}$ & $\begin{array}{c}0.4 \\
1\end{array}$ & $\begin{array}{c}42 \\
7\end{array}$ & $\begin{array}{l}2 . \\
01\end{array}$ & $\begin{array}{l}2 \\
3 \\
1\end{array}$ & $\begin{array}{l}2 \\
0\end{array}$ \\
\hline AMT 11 & $\begin{array}{c}37.7 \\
53\end{array}$ & $\begin{array}{c}38.00 \\
2\end{array}$ & $\begin{array}{c}37 . \\
99 \\
3\end{array}$ & $\begin{array}{l}0 . \\
2 \\
4 \\
9\end{array}$ & $\begin{array}{l}9 \\
6\end{array}$ & $\begin{array}{l}1 . \\
34\end{array}$ & $\begin{array}{l}0 . \\
2 \\
0\end{array}$ & $\begin{array}{l}11 \\
\text { TO }\end{array}$ & 49.5 & $\begin{array}{c}0.0 \\
6\end{array}$ & $\begin{array}{c}2.2 \\
1\end{array}$ & $\begin{array}{c}0.3 \\
6\end{array}$ & $\begin{array}{c}42 \\
3\end{array}$ & $\begin{array}{l}1 . \\
34\end{array}$ & $\begin{array}{l}1 \\
6 \\
5\end{array}$ & $\begin{array}{l}2 \\
7\end{array}$ \\
\hline AMT 12 & $\begin{array}{c}37.4 \\
25\end{array}$ & $\begin{array}{c}37.67 \\
9\end{array}$ & $\begin{array}{c}37 . \\
67 \\
3\end{array}$ & $\begin{array}{l}0 . \\
2 \\
5 \\
4\end{array}$ & $\begin{array}{l}9 \\
8\end{array}$ & $\begin{array}{l}1 . \\
31\end{array}$ & $\begin{array}{c}0 . \\
1 \\
0\end{array}$ & $\begin{array}{l}12 \\
\text { TO }\end{array}$ & 61.1 & $\begin{array}{c}0.0 \\
8\end{array}$ & $\begin{array}{c}2.0 \\
9\end{array}$ & $\begin{array}{c}0.5 \\
4\end{array}$ & $\begin{array}{c}42 \\
5\end{array}$ & $\begin{array}{c}1 . \\
31\end{array}$ & $\begin{array}{l}1 \\
6 \\
0\end{array}$ & $\begin{array}{l}4 \\
1\end{array}$ \\
\hline
\end{tabular}




\begin{tabular}{|c|c|c|c|c|c|c|c|c|c|c|c|c|c|c|c|c|}
\hline AMT 13 & $\begin{array}{c}38.8 \\
96 \\
\end{array}$ & $\begin{array}{c}39.14 \\
9 \\
\end{array}$ & $\begin{array}{c}39 . \\
13 \\
7\end{array}$ & $\begin{array}{l}0 . \\
2 \\
5 \\
3 \\
\end{array}$ & $\begin{array}{l}9 \\
5 \\
\end{array}$ & $\begin{array}{l}6 . \\
57 \\
\end{array}$ & $\begin{array}{l}2 . \\
1 \\
6\end{array}$ & $\begin{array}{l}13 \\
\text { TO } \\
\end{array}$ & $\begin{array}{c}48.4 \\
1 \\
\end{array}$ & $\begin{array}{c}0.1 \\
7 \\
\end{array}$ & $\begin{array}{c}9.5 \\
5 \\
\end{array}$ & $\begin{array}{c}0.9 \\
2 \\
\end{array}$ & $\begin{array}{c}41 \\
7 \\
\end{array}$ & $\begin{array}{c}6 . \\
57 \\
\end{array}$ & $\begin{array}{l}1 \\
4 \\
5 \\
\end{array}$ & $\begin{array}{l}1 \\
4 \\
\end{array}$ \\
\hline AMT 14 & $\begin{array}{c}37.8 \\
09\end{array}$ & $\begin{array}{c}38.05 \\
9\end{array}$ & $\begin{array}{c}38 . \\
05 \\
4\end{array}$ & $\begin{array}{l}0 . \\
2 \\
5 \\
0\end{array}$ & $\begin{array}{l}9 \\
8\end{array}$ & $\begin{array}{l}3 . \\
38\end{array}$ & $\begin{array}{l}0 . \\
4 \\
5\end{array}$ & $\begin{array}{l}14 \\
\text { TO }\end{array}$ & 60.5 & $\begin{array}{c}0.1 \\
1\end{array}$ & $\begin{array}{c}7.9 \\
9\end{array}$ & $\begin{array}{c}0.7 \\
3\end{array}$ & $\begin{array}{c}42 \\
7\end{array}$ & $\begin{array}{c}3 . \\
38\end{array}$ & $\begin{array}{l}2 \\
3 \\
6\end{array}$ & $\begin{array}{l}2 \\
2\end{array}$ \\
\hline AMT 15 & $\begin{array}{c}37.2 \\
31\end{array}$ & $\begin{array}{c}37.48 \\
2\end{array}$ & $\begin{array}{c}37 . \\
46 \\
6\end{array}$ & $\begin{array}{l}0 . \\
2 \\
5 \\
1\end{array}$ & $\begin{array}{l}9 \\
4\end{array}$ & $\begin{array}{l}3 . \\
09\end{array}$ & $\begin{array}{l}0 . \\
4 \\
0\end{array}$ & $\begin{array}{l}15 \\
\text { TO }\end{array}$ & 51.2 & 0.1 & $\begin{array}{c}3.1 \\
4 \\
\end{array}$ & $\begin{array}{c}1.2 \\
2 \\
\end{array}$ & $\begin{array}{c}41 \\
8 \\
\end{array}$ & $\begin{array}{c}3 . \\
09\end{array}$ & $\begin{array}{l}1 \\
0 \\
2\end{array}$ & $\begin{array}{l}3 \\
9 \\
\end{array}$ \\
\hline AMT 16 & $\begin{array}{c}37.3 \\
94\end{array}$ & $\begin{array}{c}37.64 \\
4\end{array}$ & $\begin{array}{c}37 . \\
63 \\
7\end{array}$ & $\begin{array}{l}0 . \\
2 \\
5 \\
0\end{array}$ & $\begin{array}{l}9 \\
7\end{array}$ & $\begin{array}{l}2 . \\
51\end{array}$ & $\begin{array}{l}0 . \\
4 \\
0\end{array}$ & $\begin{array}{l}16 \\
\text { TO }\end{array}$ & 53 & $\begin{array}{c}0.0 \\
;\end{array}$ & $\begin{array}{c}3.5 \\
4\end{array}$ & $\begin{array}{c}0.7 \\
1\end{array}$ & $\begin{array}{c}42 \\
4\end{array}$ & $\begin{array}{c}2 . \\
51\end{array}$ & $\begin{array}{l}1 \\
4 \\
1\end{array}$ & $\begin{array}{l}2 \\
8\end{array}$ \\
\hline AMT 17 & $\begin{array}{c}38.9 \\
48\end{array}$ & $\begin{array}{c}39.20 \\
1\end{array}$ & $\begin{array}{c}39 . \\
19 \\
5\end{array}$ & $\begin{array}{l}0 . \\
2 \\
5 \\
3\end{array}$ & $\begin{array}{l}9 \\
8\end{array}$ & $\begin{array}{l}3 . \\
19\end{array}$ & $\begin{array}{l}0 . \\
2 \\
8\end{array}$ & $\begin{array}{l}17 \\
\text { TO }\end{array}$ & $51 \%$ & ?.1 & $\begin{array}{c}7.7 \\
8\end{array}$ & $\begin{array}{c}1.0 \\
6\end{array}$ & $\begin{array}{c}42 \\
7\end{array}$ & $\begin{array}{l}3 . \\
19\end{array}$ & $\begin{array}{l}2 \\
4 \\
4\end{array}$ & $\begin{array}{l}3 \\
3\end{array}$ \\
\hline AMT 18 & $\begin{array}{c}36.9 \\
71\end{array}$ & $\begin{array}{c}37.22 \\
0\end{array}$ & $\begin{array}{c}37 . \\
21 \\
6\end{array}$ & $\begin{array}{l}0 . \\
2 \\
4 \\
9\end{array}$ & $\begin{array}{l}9 \\
8\end{array}$ & $\begin{array}{l}2 . \\
68\end{array}$ & $\begin{array}{l}0 . \\
2 \\
4\end{array}$ & $\begin{array}{l}18 \\
\text { TO }\end{array}$ & 73..- & $\begin{array}{c}0.0 \\
7\end{array}$ & $\begin{array}{c}7.3 \\
1\end{array}$ & $\begin{array}{c}0.4 \\
4\end{array}$ & $\begin{array}{c}42 \\
8\end{array}$ & $\begin{array}{l}2 . \\
68\end{array}$ & $\begin{array}{l}2 \\
7 \\
3\end{array}$ & $\begin{array}{l}1 \\
6\end{array}$ \\
\hline AMT 19 & $\begin{array}{c}38.0 \\
99\end{array}$ & $\begin{array}{c}38.34 \\
9\end{array}$ & $\begin{array}{c}38 . \\
20 \\
0\end{array}$ & $\begin{array}{l}0 . \\
2 \\
5 \\
0\end{array}$ & $\begin{array}{l}4 \\
0\end{array}$ & $\begin{array}{l}1 . \\
\text { oc }\end{array}$ & $\begin{array}{l}0 . \\
6 \\
7\end{array}$ & $\begin{array}{l}19 \\
\text { TO }\end{array}$ & 62.6 & $\begin{array}{c}0.0 \\
2\end{array}$ & $\begin{array}{c}0.4 \\
7\end{array}$ & $\begin{array}{c}2.4 \\
7\end{array}$ & $\begin{array}{c}43 \\
3\end{array}$ & 1 & $\begin{array}{l}4 \\
7\end{array}$ & $\begin{array}{l}2 \\
4 \\
7\end{array}$ \\
\hline AMT 20 & $\begin{array}{c}37.4 \\
65\end{array}$ & $\begin{array}{c}37.71 \\
4\end{array}$ & $\begin{array}{c}37 . \\
58 \\
4\end{array}$ & $\begin{array}{l}0 . \\
2 \\
4 \\
9\end{array}$ & $\begin{array}{l}4 \\
8\end{array}$ & $?$ & $\begin{array}{c}0 . \\
1 \\
7\end{array}$ & & & & & & & & & \\
\hline AMT 21 & $\begin{array}{c}38.1 \\
30 \\
\end{array}$ & $\begin{array}{c}38.38 \\
1\end{array}$ & $\begin{array}{c}38 . \\
26 \\
0\end{array}$ & $\begin{array}{l}0 . \\
? \\
0 \\
+\end{array}$ & $\begin{array}{l}5 \\
2\end{array}$ & $\begin{array}{l}1 . \\
68\end{array}$ & $\begin{array}{l}0 . \\
0 \\
9\end{array}$ & $\begin{array}{c}21 \mathrm{~T} \\
0\end{array}$ & 51.7 & $\begin{array}{c}0.0 \\
2\end{array}$ & $\begin{array}{c}0.9 \\
3\end{array}$ & $\begin{array}{c}1.0 \\
4\end{array}$ & $\begin{array}{c}43 \\
5\end{array}$ & $\begin{array}{l}1 . \\
68\end{array}$ & $\begin{array}{l}5 \\
5\end{array}$ & $\begin{array}{l}6 \\
2\end{array}$ \\
\hline AMT 22 & $\begin{array}{c}37.9 \\
32\end{array}$ & $\begin{array}{c}38.10 \\
2 \\
\end{array}$ & $\begin{array}{l}38 . \\
6: \\
;\end{array}$ & $\begin{array}{l}2 \\
5 \\
0\end{array}$ & $\begin{array}{l}4 \\
6\end{array}$ & $\begin{array}{l}0 . \\
75\end{array}$ & $\begin{array}{c}0 . \\
1 \\
8\end{array}$ & & & & & & & & & \\
\hline AMT 23 & $\begin{array}{c}38.6 \\
06\end{array}$ & $\begin{array}{c}38.85 \\
6\end{array}$ & $\begin{array}{c}38 . \\
84 \\
7\end{array}$ & $\begin{array}{l}0 . \\
2 \\
5 \\
0\end{array}$ & $\begin{array}{l}9 \\
6\end{array}$ & $\begin{array}{l}1 . \\
18\end{array}$ & $\begin{array}{l}0 . \\
0 \\
7\end{array}$ & $\begin{array}{l}23 \\
\text { TO }\end{array}$ & 55.3 & $\begin{array}{c}0.0 \\
6\end{array}$ & $\begin{array}{c}2.3 \\
1\end{array}$ & $\begin{array}{c}0.3 \\
2\end{array}$ & $\begin{array}{c}42 \\
7\end{array}$ & $\begin{array}{c}1 . \\
18\end{array}$ & $\begin{array}{l}1 \\
9 \\
6\end{array}$ & $\begin{array}{l}2 \\
7\end{array}$ \\
\hline AMT 24 & $\begin{array}{c}37.9 \\
81\end{array}$ & $\begin{array}{c}38.23 \\
2\end{array}$ & $\begin{array}{c}38 . \\
22 \\
9\end{array}$ & $\begin{array}{l}0 . \\
2 \\
5 \\
1\end{array}$ & $\begin{array}{l}9 \\
9\end{array}$ & $\begin{array}{l}2 . \\
01\end{array}$ & $\begin{array}{c}0 . \\
1 \\
0\end{array}$ & $\begin{array}{l}24 \\
\text { TO }\end{array}$ & 62.4 & $\begin{array}{c}0.0 \\
7\end{array}$ & $\begin{array}{c}4.3 \\
1\end{array}$ & $\begin{array}{c}0.7 \\
4\end{array}$ & $\begin{array}{c}42 \\
6\end{array}$ & $\begin{array}{l}2 . \\
01\end{array}$ & $\begin{array}{l}2 \\
1 \\
4\end{array}$ & $\begin{array}{l}3 \\
7\end{array}$ \\
\hline AMT 25 & $\begin{array}{c}37.9 \\
94\end{array}$ & $\begin{array}{c}38.24 \\
6\end{array}$ & $\begin{array}{c}38 . \\
24 \\
3\end{array}$ & $\begin{array}{l}0 . \\
2 \\
5 \\
2\end{array}$ & $\begin{array}{l}9 \\
9\end{array}$ & $\begin{array}{l}0 . \\
88\end{array}$ & $\begin{array}{l}0 . \\
0 \\
8\end{array}$ & & & & & & & & & \\
\hline $\begin{array}{l}\text { AMT } \\
25 \text { REP }\end{array}$ & $\begin{array}{c}39.1 \\
73\end{array}$ & $\begin{array}{c}39.42 \\
3\end{array}$ & $\begin{array}{c}39 . \\
41 \\
8\end{array}$ & $\begin{array}{l}0 . \\
2 \\
5 \\
0\end{array}$ & $\begin{array}{l}9 \\
8\end{array}$ & $\begin{array}{l}0 . \\
89\end{array}$ & $\begin{array}{l}0 . \\
0 \\
8\end{array}$ & & & & & & & & & \\
\hline
\end{tabular}




\begin{tabular}{|c|c|c|c|c|c|c|c|c|c|c|c|c|c|c|c|c|}
\hline AMT 26 & $\begin{array}{c}37.9 \\
61 \\
\end{array}$ & $\begin{array}{c}38.21 \\
4\end{array}$ & $\begin{array}{c}38 . \\
21 \\
2\end{array}$ & $\begin{array}{l}0 . \\
2 \\
5 \\
3\end{array}$ & $\begin{array}{l}9 \\
9 \\
\end{array}$ & $\begin{array}{l}1 . \\
97\end{array}$ & $\begin{array}{l}0 . \\
2 \\
6\end{array}$ & $\begin{array}{l}26 \\
\text { TO } \\
\end{array}$ & 51.3 & $\begin{array}{c}0.0 \\
6 \\
\end{array}$ & $\begin{array}{c}4.0 \\
6 \\
\end{array}$ & $\begin{array}{c}0.2 \\
7 \\
\end{array}$ & $\begin{array}{c}42 \\
7 \\
\end{array}$ & $\begin{array}{c}1 . \\
97\end{array}$ & $\begin{array}{l}2 \\
0 \\
6\end{array}$ & $\begin{array}{l}1 \\
4 \\
\end{array}$ \\
\hline AMT 27 & $\begin{array}{c}37.3 \\
56\end{array}$ & $\begin{array}{c}37.60 \\
5\end{array}$ & $\begin{array}{c}37 . \\
60 \\
1\end{array}$ & $\begin{array}{l}0 . \\
2 \\
4 \\
9\end{array}$ & $\begin{array}{l}9 \\
8\end{array}$ & $\begin{array}{l}2 . \\
35\end{array}$ & $\begin{array}{l}0 . \\
3 \\
7\end{array}$ & $\begin{array}{l}27 \\
\text { TO }\end{array}$ & 51.6 & $\begin{array}{c}0.0 \\
8\end{array}$ & $\begin{array}{c}4.1 \\
4\end{array}$ & $\begin{array}{c}0.6 \\
2\end{array}$ & $\begin{array}{c}42 \\
4\end{array}$ & $\begin{array}{c}2 . \\
35\end{array}$ & $\begin{array}{l}1 \\
7 \\
6\end{array}$ & $\begin{array}{l}2 \\
6\end{array}$ \\
\hline AMT 28 & $\begin{array}{c}37.1 \\
05\end{array}$ & $\begin{array}{c}37.35 \\
7\end{array}$ & $\begin{array}{c}37 . \\
33 \\
2\end{array}$ & $\begin{array}{l}0 . \\
2 \\
5 \\
2\end{array}$ & $\begin{array}{l}9 \\
0\end{array}$ & $\begin{array}{l}1 . \\
59\end{array}$ & $\begin{array}{l}0 . \\
2 \\
8\end{array}$ & $\begin{array}{l}28 \\
\text { TO }\end{array}$ & 50.2 & $\begin{array}{c}0.0 \\
5\end{array}$ & 0.9 & $\begin{array}{c}1.0 \\
3\end{array}$ & $\begin{array}{c}41 \\
9\end{array}$ & $\begin{array}{l}1 . \\
59\end{array}$ & $\begin{array}{l}5 \\
7\end{array}$ & $\begin{array}{l}6 \\
5\end{array}$ \\
\hline AMT 29 & $\begin{array}{c}38.7 \\
41\end{array}$ & $\begin{array}{c}38.99 \\
3\end{array}$ & $\begin{array}{c}38 . \\
98 \\
4\end{array}$ & $\begin{array}{l}0 . \\
2 \\
5 \\
2\end{array}$ & $\begin{array}{l}9 \\
6\end{array}$ & $\begin{array}{l}0 . \\
89\end{array}$ & $\begin{array}{l}0 . \\
0 \\
8\end{array}$ & & & & & & & & & \\
\hline AMT 30 & $\begin{array}{c}36.5 \\
72\end{array}$ & $\begin{array}{c}36.82 \\
1\end{array}$ & $\begin{array}{c}36 . \\
81 \\
2\end{array}$ & $\begin{array}{l}0 . \\
2 \\
4 \\
9\end{array}$ & $\begin{array}{l}9 \\
6\end{array}$ & $\begin{array}{l}0 . \\
90\end{array}$ & $\begin{array}{c}0 . \\
1 \\
1\end{array}$ & $\begin{array}{l}30 \\
\text { TO }\end{array}$ & 65 & ?.u & $\begin{array}{c}0.5 \\
5\end{array}$ & $\begin{array}{c}0.3 \\
3\end{array}$ & $\begin{array}{c}42 \\
8\end{array}$ & $\begin{array}{l}0 . \\
9\end{array}$ & $\begin{array}{l}6 \\
1\end{array}$ & $\begin{array}{l}3 \\
7\end{array}$ \\
\hline AMT 31 & $\begin{array}{c}38.3 \\
80\end{array}$ & $\begin{array}{c}38.62 \\
8\end{array}$ & $\begin{array}{c}38 . \\
61 \\
5\end{array}$ & $\begin{array}{l}0 . \\
2 \\
4 \\
8\end{array}$ & $\begin{array}{l}9 \\
5\end{array}$ & $\begin{array}{l}0 . \\
97\end{array}$ & $\begin{array}{c}0 . \\
1 \\
4\end{array}$ & $\begin{array}{l}31 \\
\text { TO }\end{array}$ & 47.5 & $\begin{array}{c}0.0 \\
3\end{array}$ & $\begin{array}{c}0.4 \\
4\end{array}$ & 0.4 & $\begin{array}{c}42 \\
2\end{array}$ & $\begin{array}{l}0 . \\
97\end{array}$ & $\begin{array}{l}4 \\
5\end{array}$ & $\begin{array}{l}4 \\
1\end{array}$ \\
\hline AMT 32 & $\begin{array}{c}38.4 \\
80\end{array}$ & $\begin{array}{c}38.73 \\
1\end{array}$ & $\begin{array}{c}38 . \\
72 \\
7\end{array}$ & $\begin{array}{l}0 . \\
2 \\
5 \\
1\end{array}$ & $\begin{array}{l}9 \\
8\end{array}$ & $\begin{array}{l}1 . \\
4 \delta\end{array}$ & $\begin{array}{l}0 . \\
? \\
?\end{array}$ & $\begin{array}{l}32 \\
\text { TO }\end{array}$ & 51.7 & $\begin{array}{c}0.0 \\
6\end{array}$ & $\begin{array}{c}2.4 \\
8\end{array}$ & $\begin{array}{c}0.5 \\
6\end{array}$ & $\begin{array}{c}42 \\
5\end{array}$ & $\begin{array}{l}1 . \\
48\end{array}$ & $\begin{array}{l}1 \\
6 \\
8\end{array}$ & $\begin{array}{l}3 \\
8\end{array}$ \\
\hline AMT 33 & $\begin{array}{c}38.2 \\
40\end{array}$ & $\begin{array}{c}38.48 \\
7\end{array}$ & $\begin{array}{c}38 . \\
48 \\
2\end{array}$ & $\begin{array}{l}0 . \\
2 \\
4 \\
7\end{array}$ & $\begin{array}{l}9 \\
8\end{array}$ & 34 & $\begin{array}{l}0 . \\
3 \\
1\end{array}$ & $\begin{array}{l}33 \\
\text { TO }\end{array}$ & 53.6 & $\begin{array}{c}0.0 \\
5\end{array}$ & 1.6 & $\begin{array}{c}0.2 \\
3\end{array}$ & $\begin{array}{c}42 \\
1\end{array}$ & $\begin{array}{l}1 . \\
34\end{array}$ & $\begin{array}{l}1 \\
1 \\
9\end{array}$ & $\begin{array}{l}1 \\
7\end{array}$ \\
\hline AMT 34 & $\begin{array}{c}37.5 \\
65\end{array}$ & $\begin{array}{c}37.81 \\
6\end{array}$ & $\begin{array}{c}37 . \\
80 \\
9\end{array}$ & $\begin{array}{l}0 . \\
? \\
0 \\
+\end{array}$ & $\begin{array}{l}9 \\
7\end{array}$ & $\begin{array}{l}1 . \\
14\end{array}$ & $\begin{array}{c}0 . \\
1 \\
3\end{array}$ & $\begin{array}{l}34 \\
\text { TO }\end{array}$ & 54.2 & $\begin{array}{c}0.0 \\
4\end{array}$ & $\begin{array}{c}1.6 \\
6\end{array}$ & $\begin{array}{c}0.2 \\
8\end{array}$ & $\begin{array}{c}42 \\
2\end{array}$ & $\begin{array}{l}1 . \\
14\end{array}$ & $\begin{array}{l}1 \\
4 \\
6\end{array}$ & $\begin{array}{l}2 \\
5\end{array}$ \\
\hline AMT 35 & $\begin{array}{c}37.7 \\
02 \\
\end{array}$ & $\begin{array}{c}37.95 \\
2 \\
\end{array}$ & $\begin{array}{c}37 . \\
y= \\
3\end{array}$ & $\begin{array}{l}2 \\
5 \\
0\end{array}$ & $\begin{array}{l}9 \\
1\end{array}$ & $\begin{array}{l}0 . \\
28\end{array}$ & $\begin{array}{l}0 . \\
0 \\
7\end{array}$ & & & & & & & & & \\
\hline AMT 36 & $\begin{array}{c}39.1 \\
98\end{array}$ & $\begin{array}{c}39.44 \\
9\end{array}$ & $\begin{array}{c}39 . \\
43 \\
1\end{array}$ & $\begin{array}{l}0 . \\
2 \\
5 \\
1\end{array}$ & $\begin{array}{l}9 \\
3\end{array}$ & $\begin{array}{l}0 . \\
19\end{array}$ & $\begin{array}{l}0 . \\
0 \\
8\end{array}$ & & & & & & & & & \\
\hline AMT 37 & $\begin{array}{c}38.8 \\
57\end{array}$ & $\begin{array}{c}39.11 \\
0\end{array}$ & $\begin{array}{c}39 . \\
07 \\
0\end{array}$ & $\begin{array}{l}0 . \\
2 \\
5 \\
3\end{array}$ & $\begin{array}{l}8 \\
4\end{array}$ & $\begin{array}{l}0 . \\
39\end{array}$ & $\begin{array}{c}0 . \\
1 \\
1\end{array}$ & & & & & & & & & \\
\hline $\begin{array}{c}\text { AMT } 37 \\
\text { ARG BRC }\end{array}$ & $\begin{array}{c}37.7 \\
83\end{array}$ & $\begin{array}{c}38.03 \\
5\end{array}$ & $\begin{array}{c}38 . \\
01 \\
2\end{array}$ & $\begin{array}{l}0 . \\
2 \\
5 \\
2\end{array}$ & $\begin{array}{l}9 \\
1\end{array}$ & $\begin{array}{l}1 . \\
00\end{array}$ & $\begin{array}{c}0 . \\
1 \\
8\end{array}$ & $\begin{array}{c}37 \\
\text { ARG } \\
\text { BRC }\end{array}$ & $\begin{array}{c}67.7 \\
7\end{array}$ & $\begin{array}{c}0.0 \\
2\end{array}$ & $\begin{array}{c}0.8 \\
2\end{array}$ & $\begin{array}{c}0.2 \\
2\end{array}$ & $\begin{array}{c}42 \\
6\end{array}$ & $\begin{array}{c}1 . \\
00\end{array}$ & $\begin{array}{l}8 \\
2\end{array}$ & $\begin{array}{l}2 \\
2\end{array}$ \\
\hline AMT 38 & $\begin{array}{c}38.4 \\
17\end{array}$ & $\begin{array}{c}38.66 \\
5\end{array}$ & $\begin{array}{c}38 . \\
63 \\
8\end{array}$ & $\begin{array}{l}0 . \\
2 \\
4 \\
8\end{array}$ & $\begin{array}{l}8 \\
9\end{array}$ & $\begin{array}{c}0 . \\
32\end{array}$ & $\begin{array}{c}0 . \\
1 \\
1\end{array}$ & & & & & & & & & \\
\hline
\end{tabular}




\begin{tabular}{|c|c|c|c|c|c|c|c|c|c|c|c|c|c|c|c|c|}
\hline AMT 39 & $\begin{array}{c}38.0 \\
55\end{array}$ & $\begin{array}{c}38.30 \\
6\end{array}$ & $\begin{array}{c}38 . \\
29 \\
2\end{array}$ & $\begin{array}{l}0 . \\
2 \\
5 \\
1\end{array}$ & $\begin{array}{l}9 \\
4\end{array}$ & $\begin{array}{l}3 . \\
46\end{array}$ & $\begin{array}{c}0 . \\
1 \\
4 \\
\end{array}$ & $\begin{array}{l}39 \\
\text { TO } \\
\end{array}$ & $\begin{array}{c}53.9 \\
3 \\
\end{array}$ & $\begin{array}{c}0.1 \\
1 \\
\end{array}$ & $\begin{array}{c}4.6 \\
2 \\
\end{array}$ & $\begin{array}{c}1.6 \\
4 \\
\end{array}$ & $\begin{array}{c}42 \\
2 \\
\end{array}$ & $\begin{array}{l}3 . \\
46 \\
\end{array}$ & $\begin{array}{l}1 \\
3 \\
4\end{array}$ & $\begin{array}{l}4 \\
7 \\
\end{array}$ \\
\hline AMT 40 & $\begin{array}{c}38.5 \\
79\end{array}$ & $\begin{array}{c}38.82 \\
9\end{array}$ & $\begin{array}{c}38 . \\
82 \\
1\end{array}$ & $\begin{array}{l}0 . \\
2 \\
5 \\
0\end{array}$ & $\begin{array}{l}9 \\
7\end{array}$ & $\begin{array}{l}2 . \\
78\end{array}$ & $\begin{array}{c}0 . \\
1 \\
8\end{array}$ & $\begin{array}{l}40 \\
\text { TO }\end{array}$ & $\begin{array}{c}61.6 \\
5\end{array}$ & $\begin{array}{c}0.0 \\
8\end{array}$ & $\begin{array}{c}3.2 \\
1\end{array}$ & $\begin{array}{c}1.4 \\
8\end{array}$ & $\begin{array}{c}41 \\
9\end{array}$ & $\begin{array}{l}2 . \\
78\end{array}$ & $\begin{array}{l}1 \\
1 \\
5\end{array}$ & $\begin{array}{l}5 \\
3\end{array}$ \\
\hline AMT 41 & $\begin{array}{c}38.9 \\
95\end{array}$ & $\begin{array}{c}39.24 \\
2\end{array}$ & $\begin{array}{c}39 . \\
22 \\
4\end{array}$ & $\begin{array}{l}0 . \\
2 \\
4 \\
7\end{array}$ & $\begin{array}{l}9 \\
3\end{array}$ & $\begin{array}{l}3 . \\
14\end{array}$ & $\begin{array}{c}0 . \\
1 \\
9\end{array}$ & $\begin{array}{l}41 \\
\text { TO }\end{array}$ & $\begin{array}{c}56.1 \\
3\end{array}$ & $\begin{array}{c}0.1 \\
1\end{array}$ & $\begin{array}{c}5.0 \\
5\end{array}$ & $\begin{array}{c}2.3 \\
6\end{array}$ & $\begin{array}{c}42 \\
5\end{array}$ & $\begin{array}{l}3 . \\
14\end{array}$ & $\begin{array}{l}1 \\
6 \\
1\end{array}$ & $\begin{array}{l}7 \\
5\end{array}$ \\
\hline AMT 42 & $\begin{array}{c}37.9 \\
07\end{array}$ & $\begin{array}{c}38.15 \\
6\end{array}$ & $\begin{array}{c}38 . \\
15 \\
0\end{array}$ & $\begin{array}{l}0 . \\
2 \\
4 \\
9\end{array}$ & $\begin{array}{l}9 \\
8\end{array}$ & $\begin{array}{l}3 . \\
96\end{array}$ & $\begin{array}{l}1 . \\
0 \\
6\end{array}$ & $\begin{array}{l}42 \\
\text { TO }\end{array}$ & $\begin{array}{c}59.4 \\
7\end{array}$ & $\begin{array}{c}0.1 \\
1\end{array}$ & 8.6 & 0.5 & $\begin{array}{c}42 \\
5\end{array}$ & $\begin{array}{l}3 . \\
96\end{array}$ & $\begin{array}{l}2 \\
1 \\
7\end{array}$ & $\begin{array}{l}1 \\
3\end{array}$ \\
\hline $\begin{array}{l}\text { AMT } \\
42 \text { REP }\end{array}$ & $\begin{array}{c}37.2 \\
96\end{array}$ & $\begin{array}{c}37.54 \\
5\end{array}$ & $\begin{array}{c}37 . \\
53 \\
5\end{array}$ & $\begin{array}{l}0 . \\
2 \\
4 \\
9\end{array}$ & $\begin{array}{l}9 \\
6\end{array}$ & $\begin{array}{l}3 . \\
93\end{array}$ & $\begin{array}{l}1 . \\
0 \\
6\end{array}$ & & & & & & & & & \\
\hline AMT 43 & $\begin{array}{c}38.7 \\
20\end{array}$ & $\begin{array}{c}38.97 \\
2\end{array}$ & $\begin{array}{c}38 . \\
97 \\
0\end{array}$ & $\begin{array}{l}0 . \\
2 \\
5 \\
2\end{array}$ & $\begin{array}{l}9 \\
9\end{array}$ & $\begin{array}{l}0 . \\
00\end{array}$ & $\begin{array}{l}0 . \\
0 \\
4\end{array}$ & & & & & & & & & \\
\hline AMT 44 & $\begin{array}{c}37.6 \\
06\end{array}$ & $\begin{array}{c}37.85 \\
7\end{array}$ & $\begin{array}{c}37 . \\
82 \\
8\end{array}$ & $\begin{array}{l}0 . \\
2 \\
5 \\
1\end{array}$ & $\begin{array}{l}8 \\
8\end{array}$ & $\begin{array}{l}0 . \\
62\end{array}$ & $\begin{array}{l}0 . \\
6 \\
7\end{array}$ & & & & & & & & & \\
\hline AMT 45 & $\begin{array}{c}37.7 \\
52\end{array}$ & $\begin{array}{c}38.00 \\
2\end{array}$ & $\begin{array}{c}37 . \\
99 \\
5\end{array}$ & $\begin{array}{l}0 . \\
2 \\
5 \\
0\end{array}$ & $\begin{array}{l}9 \\
7\end{array}$ & $?$ & $\begin{array}{l}0 . \\
0 \\
5\end{array}$ & & & & & & & & & \\
\hline AMT 46 & $\begin{array}{c}38.0 \\
01\end{array}$ & $\begin{array}{c}38.24 \\
9\end{array}$ & $\begin{array}{c}38 . \\
22 \\
9\end{array}$ & $\begin{array}{l}0 . \\
? \\
4 \\
c\end{array}$ & $\begin{array}{l}9 \\
2\end{array}$ & $\begin{array}{l}0 . \\
28\end{array}$ & $\begin{array}{l}0 . \\
0 \\
4\end{array}$ & & & & & & & & & \\
\hline AMT 47 & $\begin{array}{c}38.9 \\
87\end{array}$ & $\begin{array}{c}39.25 \\
7\end{array}$ & $\begin{array}{l}39 . \\
\angle ;\end{array}$ & $\begin{array}{l}2 \\
5 \\
0\end{array}$ & $\begin{array}{l}9 \\
5\end{array}$ & $\begin{array}{l}0 . \\
26\end{array}$ & $\begin{array}{l}0 . \\
0 \\
5\end{array}$ & & & & & & & & & \\
\hline AMT 48 & $\begin{array}{c}37.1 \\
61\end{array}$ & $\begin{array}{c}37.41 \\
1\end{array}$ & $\begin{array}{c}37 . \\
38 \\
5\end{array}$ & $\begin{array}{l}0 . \\
2 \\
5 \\
0\end{array}$ & $\begin{array}{l}9 \\
0\end{array}$ & $\begin{array}{l}4 . \\
24\end{array}$ & $\begin{array}{l}0 . \\
2 \\
9\end{array}$ & $\begin{array}{l}48 \\
\text { TO }\end{array}$ & $\begin{array}{c}82.4 \\
7\end{array}$ & $\begin{array}{c}0.1 \\
3\end{array}$ & $\begin{array}{c}4.9 \\
9\end{array}$ & $\begin{array}{c}1.6 \\
4\end{array}$ & $\begin{array}{c}42 \\
0\end{array}$ & $\begin{array}{l}4 . \\
24\end{array}$ & $\begin{array}{l}1 \\
1 \\
8\end{array}$ & $\begin{array}{l}3 \\
9\end{array}$ \\
\hline AMT 49 & $\begin{array}{c}37.8 \\
03\end{array}$ & $\begin{array}{c}38.05 \\
\mathbf{3}\end{array}$ & $\begin{array}{c}38 . \\
04 \\
5\end{array}$ & $\begin{array}{l}0 . \\
2 \\
5 \\
0\end{array}$ & $\begin{array}{l}9 \\
7\end{array}$ & $\begin{array}{l}1 . \\
94\end{array}$ & $\begin{array}{l}1 . \\
3 \\
1\end{array}$ & $\begin{array}{l}49 \\
\text { TO }\end{array}$ & $\begin{array}{c}83.3 \\
1\end{array}$ & $\begin{array}{c}0.0 \\
3\end{array}$ & $\begin{array}{c}2.8 \\
6\end{array}$ & 0.2 & $\begin{array}{c}43 \\
0\end{array}$ & $\begin{array}{l}1 . \\
94\end{array}$ & $\begin{array}{l}1 \\
4 \\
7\end{array}$ & $\begin{array}{l}1 \\
0\end{array}$ \\
\hline AMT 50 & $\begin{array}{c}38.8 \\
94\end{array}$ & $\begin{array}{c}39.14 \\
0\end{array}$ & $\begin{array}{c}39 . \\
12 \\
0\end{array}$ & $\begin{array}{l}0 . \\
2 \\
4 \\
6\end{array}$ & $\begin{array}{l}9 \\
2\end{array}$ & $\begin{array}{l}6 . \\
95\end{array}$ & $\begin{array}{l}2 . \\
0 \\
1\end{array}$ & $\begin{array}{l}50 \\
\text { TO }\end{array}$ & $\begin{array}{c}45.5 \\
6\end{array}$ & $\begin{array}{c}0.2 \\
6\end{array}$ & $\begin{array}{l}11 . \\
28\end{array}$ & $\begin{array}{c}1.9 \\
5\end{array}$ & $\begin{array}{c}42 \\
0\end{array}$ & $\begin{array}{l}6 . \\
95\end{array}$ & $\begin{array}{l}1 \\
6 \\
2\end{array}$ & $\begin{array}{l}2 \\
8\end{array}$ \\
\hline AMT 51 & $\begin{array}{c}38.8 \\
47\end{array}$ & $\begin{array}{c}39.09 \\
7\end{array}$ & $\begin{array}{c}39 . \\
08 \\
7\end{array}$ & $\begin{array}{l}0 . \\
2 \\
5 \\
0\end{array}$ & $\begin{array}{l}9 \\
6\end{array}$ & $\begin{array}{l}2 . \\
43\end{array}$ & $\begin{array}{l}0 . \\
0 \\
0\end{array}$ & $\begin{array}{l}51 \\
\text { TO }\end{array}$ & $\begin{array}{c}46.8 \\
1\end{array}$ & $\begin{array}{c}0.0 \\
5\end{array}$ & $\begin{array}{c}4.4 \\
7\end{array}$ & $\begin{array}{c}0.1 \\
1\end{array}$ & $\begin{array}{c}42 \\
7\end{array}$ & $\begin{array}{l}2 . \\
43\end{array}$ & $\begin{array}{l}1 \\
8 \\
4\end{array}$ & 5 \\
\hline
\end{tabular}




\begin{tabular}{|c|c|c|c|c|c|c|c|c|c|c|c|c|c|c|c|c|}
\hline AMT 52 & $\begin{array}{c}37.4 \\
75 \\
\end{array}$ & $\begin{array}{c}37.72 \\
7 \\
\end{array}$ & $\begin{array}{c}37 . \\
71 \\
2\end{array}$ & $\begin{array}{l}0 . \\
2 \\
5 \\
2\end{array}$ & $\begin{array}{l}9 \\
4 \\
\end{array}$ & $\begin{array}{l}1 . \\
53\end{array}$ & $\begin{array}{c}0 . \\
1 \\
9\end{array}$ & $\begin{array}{l}52 \\
\text { TO }\end{array}$ & 38.3 & $\begin{array}{c}0.0 \\
6\end{array}$ & $\begin{array}{c}1.8 \\
6\end{array}$ & $\begin{array}{c}0.9 \\
4\end{array}$ & $\begin{array}{c}42 \\
4\end{array}$ & $\begin{array}{l}1 . \\
53\end{array}$ & $\begin{array}{l}1 \\
2 \\
2\end{array}$ & $\begin{array}{l}6 \\
1\end{array}$ \\
\hline AMT 53 & $\begin{array}{c}37.3 \\
65\end{array}$ & $\begin{array}{c}37.61 \\
8\end{array}$ & $\begin{array}{c}37 . \\
61 \\
3\end{array}$ & $\begin{array}{l}0 . \\
2 \\
5 \\
3\end{array}$ & $\begin{array}{l}9 \\
8\end{array}$ & $\begin{array}{l}0 . \\
84\end{array}$ & $\begin{array}{l}0 . \\
4 \\
1\end{array}$ & & & & & & & & & \\
\hline AMT 54 & $\begin{array}{c}37.7 \\
26 \\
\end{array}$ & $\begin{array}{c}37.97 \\
8 \\
\end{array}$ & $\begin{array}{c}37 . \\
97 \\
0\end{array}$ & $\begin{array}{l}0 . \\
2 \\
5 \\
2\end{array}$ & $\begin{array}{l}9 \\
7\end{array}$ & $\begin{array}{l}1 . \\
00\end{array}$ & $\begin{array}{c}0 . \\
1 \\
0\end{array}$ & $\begin{array}{l}54 \\
\text { TO }\end{array}$ & 62.7 & $\begin{array}{c}0.0 \\
4 \\
\end{array}$ & $\begin{array}{c}2.8 \\
2 \\
\end{array}$ & $\begin{array}{c}0.3 \\
8 \\
\end{array}$ & $\begin{array}{c}43 \\
2 \\
\end{array}$ & 1 & $\begin{array}{l}2 \\
8 \\
2\end{array}$ & $\begin{array}{l}3 \\
8 \\
\end{array}$ \\
\hline AMT 55 & $\begin{array}{c}38.5 \\
42 \\
\end{array}$ & $\begin{array}{c}38.79 \\
5\end{array}$ & $\begin{array}{c}38 . \\
79 \\
3\end{array}$ & $\begin{array}{l}0 . \\
2 \\
5 \\
3\end{array}$ & $\begin{array}{l}9 \\
9 \\
\end{array}$ & $\begin{array}{l}3 . \\
05\end{array}$ & $\begin{array}{l}0 . \\
3 \\
1\end{array}$ & $\begin{array}{l}55 \\
\text { TO }\end{array}$ & 51.1 & $\begin{array}{c}0.0 \\
b\end{array}$ & $\begin{array}{c}9.2 \\
6 \\
\end{array}$ & $\begin{array}{c}0.7 \\
6 \\
\end{array}$ & $\begin{array}{c}42 \\
9 \\
\end{array}$ & $\begin{array}{c}3 . \\
05 \\
\end{array}$ & $\begin{array}{l}3 \\
0 \\
4\end{array}$ & $\begin{array}{l}2 \\
5 \\
\end{array}$ \\
\hline AMT 58 & $\begin{array}{c}37.9 \\
30\end{array}$ & $\begin{array}{c}38.18 \\
3\end{array}$ & $\begin{array}{c}38 . \\
18 \\
0\end{array}$ & $\begin{array}{l}0 . \\
2 \\
5 \\
3\end{array}$ & $\begin{array}{l}9 \\
9\end{array}$ & $\begin{array}{l}2 . \\
37\end{array}$ & $\begin{array}{l}0 . \\
7 \\
8\end{array}$ & $\begin{array}{l}58 \\
\text { TO }\end{array}$ & 388 & $\begin{array}{r}? .0 \\
,\end{array}$ & $\begin{array}{c}7.3 \\
6\end{array}$ & 0.3 & $\begin{array}{c}42 \\
9 \\
\end{array}$ & $\begin{array}{c}2 . \\
37 \\
\end{array}$ & $\begin{array}{l}3 \\
1 \\
1\end{array}$ & $\begin{array}{l}1 \\
3\end{array}$ \\
\hline AMT 59 & $\begin{array}{c}37.1 \\
78\end{array}$ & $\begin{array}{c}37.42 \\
9\end{array}$ & $\begin{array}{c}37 . \\
42 \\
5\end{array}$ & $\begin{array}{l}0 . \\
2 \\
5 \\
1\end{array}$ & $\begin{array}{l}9 \\
8\end{array}$ & $\begin{array}{l}2 . \\
75\end{array}$ & $\begin{array}{c}0 . \\
1 \\
1\end{array}$ & $\begin{array}{l}59 \\
\text { TO }\end{array}$ & 42.: & $\begin{array}{c}0.0 \\
8\end{array}$ & $\begin{array}{c}9.8 \\
7\end{array}$ & $\begin{array}{c}0.8 \\
2\end{array}$ & $\begin{array}{c}43 \\
1\end{array}$ & $\begin{array}{l}2 . \\
75\end{array}$ & $\begin{array}{l}3 \\
5 \\
9\end{array}$ & $\begin{array}{l}3 \\
0\end{array}$ \\
\hline AMT 60 & $\begin{array}{c}39.0 \\
30\end{array}$ & $\begin{array}{c}39.28 \\
1\end{array}$ & $\begin{array}{c}39 . \\
27 \\
6\end{array}$ & $\begin{array}{l}0 . \\
2 \\
5 \\
1\end{array}$ & $\begin{array}{l}9 \\
8\end{array}$ & $\begin{array}{l}2 . \\
3 C\end{array}$ & $\begin{array}{l}0 . \\
: \\
1\end{array}$ & $\begin{array}{l}50 \\
\text { TO }\end{array}$ & 48.2 & $\begin{array}{c}0.0 \\
4\end{array}$ & $\begin{array}{c}6.1 \\
5\end{array}$ & $\begin{array}{c}0.4 \\
9\end{array}$ & $\begin{array}{c}42 \\
6\end{array}$ & $\begin{array}{l}2 . \\
3\end{array}$ & $\begin{array}{l}2 \\
6 \\
7\end{array}$ & $\begin{array}{l}2 \\
1\end{array}$ \\
\hline AMT 61 & $\begin{array}{c}38.2 \\
14\end{array}$ & $\begin{array}{c}38.46 \\
5\end{array}$ & $\begin{array}{c}38 . \\
46 \\
1\end{array}$ & $\begin{array}{l}0 . \\
2 \\
5 \\
1\end{array}$ & $\begin{array}{l}9 \\
8\end{array}$ & 16 & $\begin{array}{l}0 . \\
8 \\
5\end{array}$ & $\begin{array}{l}61 \\
\text { TO }\end{array}$ & 58.7 & $\begin{array}{c}0.0 \\
6\end{array}$ & 7.9 & $\begin{array}{c}0.3 \\
1\end{array}$ & $\begin{array}{c}42 \\
7\end{array}$ & $\begin{array}{c}2 . \\
76 \\
\end{array}$ & $\begin{array}{l}2 \\
8 \\
6\end{array}$ & $\begin{array}{l}1 \\
1 \\
\end{array}$ \\
\hline AMT 62 & $\begin{array}{c}36.8 \\
06\end{array}$ & $\begin{array}{c}37.05 \\
9 \\
\end{array}$ & $\begin{array}{c}37 . \\
05 \\
3\end{array}$ & $\begin{array}{l}0 . \\
? \\
0 \\
0\end{array}$ & $\begin{array}{l}9 \\
8\end{array}$ & $\begin{array}{l}3 . \\
03\end{array}$ & $\begin{array}{l}1 . \\
0 \\
5\end{array}$ & $\begin{array}{l}62 \\
\text { TO }\end{array}$ & 44.9 & $\begin{array}{c}0.0 \\
7\end{array}$ & $\begin{array}{c}10 . \\
18\end{array}$ & $\begin{array}{c}0.2 \\
5\end{array}$ & $\begin{array}{c}42 \\
8\end{array}$ & $\begin{array}{l}3 . \\
03\end{array}$ & $\begin{array}{l}3 \\
3 \\
6\end{array}$ & 8 \\
\hline $\begin{array}{l}\text { AMT } \\
62 \text { REP }\end{array}$ & $\begin{array}{c}39.2 \\
36\end{array}$ & $\begin{array}{c}39.40 \\
9\end{array}$ & $\begin{array}{l}39 . \\
40 \\
j\end{array}$ & $\begin{array}{l}2 \\
5 \\
3\end{array}$ & $\begin{array}{l}9 \\
8\end{array}$ & $\begin{array}{l}3 . \\
06\end{array}$ & $\begin{array}{l}1 . \\
0 \\
5\end{array}$ & & & & & & & & & \\
\hline AMT 63 & $\begin{array}{c}38.8 \\
87\end{array}$ & $\begin{array}{c}39.13 \\
8\end{array}$ & $\begin{array}{c}39 . \\
13 \\
5\end{array}$ & $\begin{array}{l}0 . \\
2 \\
5 \\
1\end{array}$ & $\begin{array}{l}9 \\
9\end{array}$ & $\begin{array}{l}2 . \\
70\end{array}$ & $\begin{array}{l}0 . \\
3 \\
1\end{array}$ & $\begin{array}{l}63 \\
\text { TO }\end{array}$ & 50.2 & $\begin{array}{c}0.0 \\
7\end{array}$ & 8.6 & $\begin{array}{c}0.4 \\
7\end{array}$ & $\begin{array}{c}42 \\
9\end{array}$ & $\begin{array}{l}2 . \\
7\end{array}$ & $\begin{array}{l}3 \\
1 \\
9\end{array}$ & $\begin{array}{l}1 \\
7\end{array}$ \\
\hline AMT 64 & $\begin{array}{c}39.3 \\
96\end{array}$ & $\begin{array}{c}39.64 \\
5\end{array}$ & $\begin{array}{c}39 . \\
64 \\
1\end{array}$ & $\begin{array}{l}0 . \\
2 \\
4 \\
9\end{array}$ & $\begin{array}{l}9 \\
8\end{array}$ & $\begin{array}{l}2 . \\
38\end{array}$ & $\begin{array}{c}0 . \\
1 \\
3\end{array}$ & $\begin{array}{l}64 \\
\text { TO }\end{array}$ & 62.9 & $\begin{array}{c}0.0 \\
6\end{array}$ & $\begin{array}{c}6.1 \\
8\end{array}$ & $\begin{array}{c}0.9 \\
7\end{array}$ & $\begin{array}{c}42 \\
7\end{array}$ & $\begin{array}{l}2 . \\
38\end{array}$ & $\begin{array}{l}2 \\
6 \\
0\end{array}$ & $\begin{array}{l}4 \\
1\end{array}$ \\
\hline AMT 65 & $\begin{array}{c}37.6 \\
15 \\
\end{array}$ & $\begin{array}{c}37.86 \\
5\end{array}$ & $\begin{array}{c}37 . \\
86 \\
2\end{array}$ & $\begin{array}{l}0 . \\
2 \\
5 \\
0\end{array}$ & $\begin{array}{l}9 \\
9\end{array}$ & $\begin{array}{l}2 . \\
31\end{array}$ & $\begin{array}{l}0 . \\
4 \\
4\end{array}$ & $\begin{array}{l}65 \\
\text { TO }\end{array}$ & 46.5 & $\begin{array}{c}0.0 \\
5\end{array}$ & 7.2 & $\begin{array}{c}0.5 \\
2\end{array}$ & $\begin{array}{c}42 \\
6\end{array}$ & $\begin{array}{l}2 . \\
31\end{array}$ & $\begin{array}{l}3 \\
1 \\
2\end{array}$ & $\begin{array}{l}2 \\
3\end{array}$ \\
\hline AMT 66 & $\begin{array}{c}37.2 \\
19\end{array}$ & $\begin{array}{c}37.47 \\
1\end{array}$ & $\begin{array}{c}37 . \\
46 \\
8\end{array}$ & $\begin{array}{l}0 . \\
2 \\
5 \\
2\end{array}$ & $\begin{array}{l}9 \\
9\end{array}$ & $\begin{array}{l}2 . \\
32\end{array}$ & $\begin{array}{c}0 . \\
1 \\
3\end{array}$ & $\begin{array}{l}66 \\
\text { TO }\end{array}$ & 57.9 & $\begin{array}{c}0.0 \\
7\end{array}$ & $\begin{array}{c}7.6 \\
1\end{array}$ & $\begin{array}{c}0.7 \\
9\end{array}$ & $\begin{array}{c}43 \\
1\end{array}$ & $\begin{array}{l}2 . \\
32\end{array}$ & $\begin{array}{l}3 \\
2 \\
8\end{array}$ & $\begin{array}{l}3 \\
4\end{array}$ \\
\hline
\end{tabular}




\begin{tabular}{|c|c|c|c|c|c|c|c|c|c|c|c|c|c|c|c|c|}
\hline АMT 67 & $\begin{array}{c}38.2 \\
17\end{array}$ & $\begin{array}{c}38.47 \\
1\end{array}$ & $\begin{array}{c}38 . \\
46 \\
5\end{array}$ & $\begin{array}{l}0 . \\
2 \\
5 \\
4\end{array}$ & $\begin{array}{l}9 \\
8\end{array}$ & $\begin{array}{c}3 . \\
05\end{array}$ & $\begin{array}{l}1 . \\
4 \\
5\end{array}$ & $\begin{array}{l}67 \\
\text { TO }\end{array}$ & 51.2 & $\begin{array}{c}0.0 \\
9\end{array}$ & $\begin{array}{c}8.9 \\
4\end{array}$ & $\begin{array}{c}0.2 \\
4\end{array}$ & $\begin{array}{c}42 \\
7\end{array}$ & $\begin{array}{c}3 . \\
05\end{array}$ & $\begin{array}{l}2 \\
9 \\
3\end{array}$ & 8 \\
\hline AMT 68 & $\begin{array}{c}37.5 \\
02\end{array}$ & $\begin{array}{c}37.75 \\
\mathbf{3}\end{array}$ & $\begin{array}{c}37 . \\
74 \\
6\end{array}$ & $\begin{array}{l}0 . \\
2 \\
5 \\
1\end{array}$ & $\begin{array}{l}9 \\
7\end{array}$ & $\begin{array}{l}3 . \\
49\end{array}$ & $\begin{array}{l}0 . \\
4 \\
3\end{array}$ & $\begin{array}{l}68 \\
\text { TO }\end{array}$ & 41.2 & $\begin{array}{c}0.1 \\
2\end{array}$ & $\begin{array}{c}9.2 \\
7\end{array}$ & 0.9 & $\begin{array}{c}42 \\
7\end{array}$ & $\begin{array}{l}3 . \\
49\end{array}$ & $\begin{array}{l}2 \\
6 \\
6\end{array}$ & $\begin{array}{l}2 \\
6\end{array}$ \\
\hline AMT 69 & $\begin{array}{c}39.0 \\
32\end{array}$ & $\begin{array}{c}39.28 \\
2\end{array}$ & $\begin{array}{c}39 . \\
27 \\
4\end{array}$ & $\begin{array}{l}0 . \\
2 \\
5 \\
0\end{array}$ & $\begin{array}{l}9 \\
7\end{array}$ & $\begin{array}{l}1 . \\
72\end{array}$ & $\begin{array}{l}0 . \\
2 \\
8\end{array}$ & $\begin{array}{l}69 \\
\text { TO }\end{array}$ & 59.7 & $\begin{array}{c}0.0 \\
6\end{array}$ & $\begin{array}{c}2.6 \\
9\end{array}$ & $\begin{array}{c}0.7 \\
5\end{array}$ & $\begin{array}{c}42 \\
1\end{array}$ & $\begin{array}{l}1 . \\
72\end{array}$ & $\begin{array}{l}1 \\
5 \\
6\end{array}$ & $\begin{array}{l}4 \\
4\end{array}$ \\
\hline AMT 70 & $\begin{array}{c}38.5 \\
90\end{array}$ & $\begin{array}{c}38.84 \\
1\end{array}$ & $\begin{array}{c}38 . \\
84 \\
0\end{array}$ & $\begin{array}{l}0 . \\
2 \\
5 \\
1\end{array}$ & $\begin{array}{l}1 \\
0 \\
0\end{array}$ & $\begin{array}{c}0 . \\
99\end{array}$ & $\begin{array}{c}0 . \\
1 \\
2\end{array}$ & $\begin{array}{l}70 \\
\text { TO }\end{array}$ & 50.7 & $\begin{array}{c}0.0 \\
\dot{3}\end{array}$ & $\begin{array}{c}1.5 \\
2 \\
\end{array}$ & $\begin{array}{c}0.3 \\
9\end{array}$ & $\begin{array}{c}42 \\
9\end{array}$ & $\begin{array}{c}0 . \\
99\end{array}$ & $\begin{array}{l}1 \\
5 \\
4\end{array}$ & $\begin{array}{l}3 \\
9 \\
\end{array}$ \\
\hline AMT 71 & $\begin{array}{c}38.0 \\
54\end{array}$ & $\begin{array}{c}38.30 \\
7\end{array}$ & $\begin{array}{c}38 . \\
30 \\
1\end{array}$ & $\begin{array}{l}0 . \\
2 \\
5 \\
3\end{array}$ & $\begin{array}{l}9 \\
8\end{array}$ & $\begin{array}{c}1 . \\
24\end{array}$ & $\begin{array}{c}0 . \\
4 \\
6\end{array}$ & $\begin{array}{l}71 \\
\text { TO }\end{array}$ & & ?.u & $\begin{array}{c}1.8 \\
3\end{array}$ & $\begin{array}{c}0.1 \\
8\end{array}$ & $\begin{array}{c}42 \\
7\end{array}$ & $\begin{array}{c}1 . \\
24\end{array}$ & $\begin{array}{l}1 \\
4 \\
8\end{array}$ & $\begin{array}{l}1 \\
5\end{array}$ \\
\hline AMT 72 & $\begin{array}{c}38.9 \\
12\end{array}$ & $\begin{array}{c}39.15 \\
8\end{array}$ & $\begin{array}{c}39 . \\
14 \\
8\end{array}$ & $\begin{array}{l}0 . \\
2 \\
4 \\
6\end{array}$ & $\begin{array}{l}9 \\
6\end{array}$ & $\begin{array}{l}0 . \\
92\end{array}$ & $\begin{array}{l}0 . \\
3 \\
2\end{array}$ & & & & & & & & & \\
\hline AMT 73 & $\begin{array}{c}37.0 \\
25\end{array}$ & $\begin{array}{c}37.27 \\
8\end{array}$ & $\begin{array}{c}37 . \\
27 \\
2\end{array}$ & $\begin{array}{l}0 . \\
2 \\
5 \\
3\end{array}$ & $\begin{array}{l}9 \\
8\end{array}$ & $\begin{array}{l}1 . \\
01\end{array}$ & $\begin{array}{l}0 . \\
\dot{f}\end{array}$ & $\begin{array}{l}73 \\
\text { TO }\end{array}$ & 47.9 & $\begin{array}{c}0.0 \\
3\end{array}$ & $\begin{array}{c}1.1 \\
7\end{array}$ & $\begin{array}{c}0.2 \\
8\end{array}$ & $\begin{array}{c}42 \\
7\end{array}$ & $\begin{array}{c}1 . \\
01\end{array}$ & $\begin{array}{l}1 \\
1 \\
6\end{array}$ & $\begin{array}{l}2 \\
8\end{array}$ \\
\hline AMT 74 & $\begin{array}{c}37.7 \\
26\end{array}$ & $\begin{array}{c}37.97 \\
5\end{array}$ & $\begin{array}{c}37 . \\
96 \\
8\end{array}$ & $\begin{array}{l}0 . \\
2 \\
4 \\
9\end{array}$ & $\begin{array}{l}9 \\
7\end{array}$ & 22 & $\begin{array}{l}0 . \\
5 \\
4\end{array}$ & $\begin{array}{c}74 T \\
0\end{array}$ & 61 & $\begin{array}{c}0.0 \\
3\end{array}$ & $\begin{array}{c}0.8 \\
7\end{array}$ & $\begin{array}{c}0.2 \\
4\end{array}$ & $\begin{array}{c}42 \\
0\end{array}$ & $\begin{array}{l}1 . \\
22\end{array}$ & $\begin{array}{l}7 \\
1\end{array}$ & $\begin{array}{l}2 \\
0\end{array}$ \\
\hline AMT 75 & $\begin{array}{c}37.4 \\
50\end{array}$ & $\begin{array}{c}37.70 \\
1\end{array}$ & $\begin{array}{c}37 . \\
69 \\
4\end{array}$ & $\begin{array}{l}0 . \\
? \\
0 \\
+\end{array}$ & $\begin{array}{l}9 \\
7\end{array}$ & $\begin{array}{l}2 . \\
80\end{array}$ & $\begin{array}{l}0 . \\
2 \\
7\end{array}$ & $\begin{array}{l}75 \\
\text { TO }\end{array}$ & 45.4 & $\begin{array}{c}0.1 \\
3\end{array}$ & $\begin{array}{c}8.9 \\
9\end{array}$ & $\begin{array}{c}1.7 \\
3\end{array}$ & $\begin{array}{c}42 \\
4\end{array}$ & $\begin{array}{c}2 . \\
8\end{array}$ & $\begin{array}{l}3 \\
2 \\
1\end{array}$ & $\begin{array}{l}6 \\
2\end{array}$ \\
\hline AMT 76 & $\begin{array}{c}38.9 \\
00\end{array}$ & $\begin{array}{c}39.1 \mathrm{~b} \\
0\end{array}$ & $\begin{array}{l}39 . \\
1: \\
;\end{array}$ & $\begin{array}{l}n \\
2 \\
5 \\
0\end{array}$ & $\begin{array}{l}9 \\
8\end{array}$ & $\begin{array}{l}4 . \\
20\end{array}$ & $\begin{array}{l}1 . \\
2 \\
4\end{array}$ & $\begin{array}{l}76 \\
\text { TO }\end{array}$ & 47.4 & $\begin{array}{c}0.0 \\
3\end{array}$ & $\begin{array}{c}5.0 \\
6\end{array}$ & $\begin{array}{c}0.3 \\
1\end{array}$ & $\begin{array}{c}43 \\
3\end{array}$ & $\begin{array}{c}4 . \\
2\end{array}$ & $\begin{array}{l}1 \\
2 \\
0\end{array}$ & 7 \\
\hline AMT 77 & $\begin{array}{c}38.1 \\
94\end{array}$ & $\begin{array}{c}38.44 \\
4\end{array}$ & $\begin{array}{c}38 . \\
44 \\
1\end{array}$ & $\begin{array}{l}0 . \\
2 \\
5 \\
0\end{array}$ & $\begin{array}{l}9 \\
9\end{array}$ & $\begin{array}{l}3 . \\
82\end{array}$ & $\begin{array}{l}0 . \\
5 \\
6\end{array}$ & $\begin{array}{l}77 \\
\text { TO }\end{array}$ & 40.4 & $\begin{array}{c}0.0 \\
4\end{array}$ & $\begin{array}{c}3.9 \\
3\end{array}$ & $\begin{array}{c}0.4 \\
5\end{array}$ & $\begin{array}{c}43 \\
2\end{array}$ & $\begin{array}{l}3 . \\
82\end{array}$ & $\begin{array}{l}1 \\
0 \\
3\end{array}$ & $\begin{array}{l}1 \\
2\end{array}$ \\
\hline AMT 78 & $\begin{array}{c}38.3 \\
30\end{array}$ & $\begin{array}{c}38.58 \\
0\end{array}$ & $\begin{array}{c}38 . \\
57 \\
5\end{array}$ & $\begin{array}{l}0 . \\
2 \\
5 \\
0\end{array}$ & $\begin{array}{l}9 \\
8\end{array}$ & $\begin{array}{l}3 . \\
73\end{array}$ & $\begin{array}{l}0 . \\
3 \\
2\end{array}$ & $\begin{array}{l}78 \\
\text { TO }\end{array}$ & 49.8 & $\begin{array}{c}0.0 \\
3\end{array}$ & $\begin{array}{c}3.7 \\
2\end{array}$ & $\begin{array}{c}0.2 \\
1\end{array}$ & $\begin{array}{c}43 \\
2\end{array}$ & $\begin{array}{l}3 . \\
73\end{array}$ & $\begin{array}{l}1 \\
0 \\
0\end{array}$ & 6 \\
\hline AMT 80 & $\begin{array}{c}37.0 \\
50\end{array}$ & $\begin{array}{c}37.30 \\
2\end{array}$ & $\begin{array}{c}37 . \\
29 \\
4\end{array}$ & $\begin{array}{l}0 . \\
2 \\
5 \\
2\end{array}$ & $\begin{array}{l}9 \\
7\end{array}$ & $\begin{array}{l}0 . \\
43\end{array}$ & $\begin{array}{c}0 . \\
1 \\
2\end{array}$ & & & & & & & & & \\
\hline AMT 81 & $\begin{array}{c}37.5 \\
92\end{array}$ & $\begin{array}{c}37.84 \\
2\end{array}$ & $\begin{array}{c}37 . \\
82 \\
4\end{array}$ & $\begin{array}{l}0 . \\
2 \\
5 \\
0\end{array}$ & $\begin{array}{l}9 \\
3\end{array}$ & $\begin{array}{c}0 . \\
91\end{array}$ & $\begin{array}{c}0 . \\
1 \\
6\end{array}$ & & & & & & & & & \\
\hline
\end{tabular}




\begin{tabular}{|c|c|c|c|c|c|c|c|c|c|c|c|c|c|c|c|c|}
\hline $\begin{array}{l}\text { AMT } \\
81 \text { REP }\end{array}$ & $\begin{array}{c}38.8 \\
20\end{array}$ & $\begin{array}{c}39.07 \\
0\end{array}$ & $\begin{array}{c}39 . \\
05 \\
3\end{array}$ & $\begin{array}{l}2 \\
5 \\
0\end{array}$ & $\begin{array}{l}9 \\
3\end{array}$ & $\begin{array}{l}0 . \\
91\end{array}$ & $\begin{array}{c}0 . \\
1 \\
6\end{array}$ & & & & & & & & & \\
\hline AMT 82 & $\begin{array}{c}37.5 \\
31\end{array}$ & $\begin{array}{c}37.78 \\
2\end{array}$ & $\begin{array}{c}37 . \\
76 \\
5\end{array}$ & $\begin{array}{l}0 . \\
2 \\
5 \\
1\end{array}$ & $\begin{array}{l}9 \\
3\end{array}$ & $\begin{array}{l}1 . \\
27\end{array}$ & $\begin{array}{c}0 . \\
1 \\
9\end{array}$ & $\begin{array}{l}82 \\
\text { TO }\end{array}$ & 65.3 & $\begin{array}{c}0.0 \\
8\end{array}$ & $\begin{array}{c}4.3 \\
1\end{array}$ & $\begin{array}{c}0.2 \\
4\end{array}$ & $\begin{array}{c}42 \\
4\end{array}$ & $\begin{array}{l}1 . \\
27\end{array}$ & $\begin{array}{l}3 \\
3 \\
9\end{array}$ & $\begin{array}{l}1 \\
9\end{array}$ \\
\hline AMT 83 & $\begin{array}{c}39.2 \\
56\end{array}$ & $\begin{array}{c}39.50 \\
9\end{array}$ & $\begin{array}{c}39 . \\
50 \\
4\end{array}$ & $\begin{array}{l}0 . \\
2 \\
5 \\
3\end{array}$ & $\begin{array}{l}9 \\
8\end{array}$ & $\begin{array}{l}1 . \\
00\end{array}$ & $\begin{array}{c}0 . \\
1 \\
2\end{array}$ & $\begin{array}{l}83 \\
\text { TO }\end{array}$ & 75.7 & $\begin{array}{c}0.0 \\
6\end{array}$ & $\begin{array}{c}2.0 \\
7\end{array}$ & $\begin{array}{c}0.3 \\
1\end{array}$ & $\begin{array}{c}42 \\
1\end{array}$ & $\begin{array}{c}1 . \\
00\end{array}$ & $\begin{array}{l}2 \\
0 \\
7\end{array}$ & $\begin{array}{l}3 \\
1\end{array}$ \\
\hline AMT 84 & $\begin{array}{c}36.7 \\
00\end{array}$ & $\begin{array}{c}36.95 \\
2\end{array}$ & $\begin{array}{c}36 . \\
95 \\
0\end{array}$ & $\begin{array}{l}0 . \\
2 \\
5 \\
2\end{array}$ & $\begin{array}{l}9 \\
9\end{array}$ & $\begin{array}{l}1 . \\
04\end{array}$ & $\begin{array}{c}0 . \\
1 \\
2\end{array}$ & $\begin{array}{l}84 \\
\text { TO }\end{array}$ & 62.8 & $\begin{array}{c}0.0 \\
\gamma\end{array}$ & $\begin{array}{c}2.1 \\
2\end{array}$ & $\begin{array}{c}0.2 \\
3\end{array}$ & $\begin{array}{c}42 \\
2\end{array}$ & $\begin{array}{c}1 . \\
04\end{array}$ & $\begin{array}{l}2 \\
0 \\
4\end{array}$ & $\begin{array}{l}2 \\
2\end{array}$ \\
\hline AMT 85 & $\begin{array}{c}37.7 \\
33\end{array}$ & $\begin{array}{c}37.98 \\
1\end{array}$ & $\begin{array}{c}37 . \\
97 \\
7\end{array}$ & $\begin{array}{l}0 . \\
2 \\
4 \\
8\end{array}$ & $\begin{array}{l}9 \\
8\end{array}$ & $\begin{array}{l}2 . \\
69\end{array}$ & $\begin{array}{l}1 . \\
0 \\
3\end{array}$ & $\begin{array}{l}85 \\
\text { TO }\end{array}$ & $5 ? 4$ & ?.u & $\begin{array}{c}3.0 \\
2\end{array}$ & $\begin{array}{c}0.3 \\
5\end{array}$ & $\begin{array}{c}42 \\
2\end{array}$ & $\begin{array}{l}2 . \\
69\end{array}$ & $\begin{array}{l}1 \\
1 \\
2\end{array}$ & $\begin{array}{l}1 \\
3\end{array}$ \\
\hline AMT 86 & $\begin{array}{c}38.2 \\
73\end{array}$ & $\begin{array}{c}38.52 \\
2\end{array}$ & $\begin{array}{c}38 . \\
50 \\
2\end{array}$ & $\begin{array}{l}0 . \\
2 \\
4 \\
9\end{array}$ & $\begin{array}{l}9 \\
2\end{array}$ & $\begin{array}{l}2 . \\
46\end{array}$ & $\begin{array}{l}3 . \\
8 \\
5\end{array}$ & $\begin{array}{l}86 \\
\text { TO }\end{array}$ & 64.7 & $\begin{array}{c}0.0 \\
5\end{array}$ & $\begin{array}{c}2.9 \\
9\end{array}$ & $\begin{array}{c}0.2 \\
7\end{array}$ & $\begin{array}{c}42 \\
1\end{array}$ & $\begin{array}{c}2 . \\
46\end{array}$ & $\begin{array}{l}1 \\
2 \\
2\end{array}$ & $\begin{array}{l}1 \\
1\end{array}$ \\
\hline AMT 87 & $\begin{array}{c}37.9 \\
68\end{array}$ & $\begin{array}{c}38.21 \\
7\end{array}$ & $\begin{array}{c}38 . \\
20 \\
4\end{array}$ & $\begin{array}{l}0 . \\
2 \\
4 \\
9\end{array}$ & $\begin{array}{l}9 \\
5\end{array}$ & $\begin{array}{l}2 . \\
5 C\end{array}$ & $\begin{array}{l}2 . \\
0 \\
c\end{array}$ & $\begin{array}{l}97 \\
\text { TO }\end{array}$ & 45.3 & $\begin{array}{c}0.2 \\
2\end{array}$ & $\begin{array}{c}5.8 \\
9\end{array}$ & $\begin{array}{c}1.1 \\
5\end{array}$ & $\begin{array}{c}42 \\
8\end{array}$ & $\begin{array}{l}2 . \\
50\end{array}$ & $\begin{array}{l}2 \\
3 \\
6\end{array}$ & $\begin{array}{l}4 \\
6\end{array}$ \\
\hline AMT 88 & $\begin{array}{c}38.7 \\
69\end{array}$ & $\begin{array}{c}39.01 \\
7\end{array}$ & $\begin{array}{c}39 . \\
00 \\
8\end{array}$ & $\begin{array}{l}0 . \\
2 \\
4 \\
8\end{array}$ & $\begin{array}{l}9 \\
6\end{array}$ & ?4 & $\begin{array}{l}4 . \\
1 \\
5\end{array}$ & $\begin{array}{l}88 \\
\text { TO }\end{array}$ & 47.8 & $\begin{array}{c}0.0 \\
6\end{array}$ & $\begin{array}{c}3.2 \\
7\end{array}$ & $\begin{array}{c}0.6 \\
5\end{array}$ & $\begin{array}{c}42 \\
5\end{array}$ & $\begin{array}{l}2 . \\
84\end{array}$ & $\begin{array}{l}1 \\
1 \\
5\end{array}$ & $\begin{array}{l}2 \\
3\end{array}$ \\
\hline AMT 89 & $\begin{array}{c}38.5 \\
49\end{array}$ & $\begin{array}{c}38.80 \\
2\end{array}$ & $\begin{array}{c}38 . \\
80 \\
0\end{array}$ & i & $\begin{array}{l}9 \\
9\end{array}$ & $\begin{array}{l}2 . \\
05\end{array}$ & $\begin{array}{c}0 . \\
1 \\
0\end{array}$ & $\begin{array}{l}89 \\
\text { TO }\end{array}$ & 48.8 & $\begin{array}{c}0.0 \\
4\end{array}$ & $\begin{array}{c}1.1 \\
6\end{array}$ & $\begin{array}{c}0.5 \\
6\end{array}$ & $\begin{array}{c}42 \\
6\end{array}$ & $\begin{array}{c}2 . \\
05\end{array}$ & $\begin{array}{l}5 \\
7\end{array}$ & $\begin{array}{l}2 \\
7\end{array}$ \\
\hline AMT 90 & $\begin{array}{c}37.4 \\
35\end{array}$ & $\begin{array}{c}37.60 \\
7\end{array}$ & $\begin{array}{l}37 . \\
0 \\
;\end{array}$ & $\begin{array}{l}2 \\
5 \\
2\end{array}$ & $\begin{array}{l}9 \\
9\end{array}$ & $\begin{array}{l}1 . \\
83\end{array}$ & $\begin{array}{l}0 . \\
0 \\
7\end{array}$ & $\begin{array}{l}90 \\
\text { TO }\end{array}$ & 42.6 & $\begin{array}{c}0.0 \\
4\end{array}$ & $\begin{array}{c}1.6 \\
3\end{array}$ & 0.7 & $\begin{array}{c}42 \\
5\end{array}$ & $\begin{array}{l}1 . \\
83\end{array}$ & $\begin{array}{l}8 \\
9\end{array}$ & $\begin{array}{l}3 \\
8\end{array}$ \\
\hline AMT 91 & $\begin{array}{c}37.1 \\
12\end{array}$ & $\begin{array}{c}37.36 \\
5\end{array}$ & $\begin{array}{c}37 . \\
36 \\
5\end{array}$ & $\begin{array}{l}0 . \\
2 \\
5 \\
3\end{array}$ & $\begin{array}{l}1 \\
0 \\
0\end{array}$ & $\begin{array}{l}1 . \\
69\end{array}$ & $\begin{array}{l}0 . \\
2 \\
4\end{array}$ & $\begin{array}{l}91 \\
\text { TO }\end{array}$ & 53.9 & $\begin{array}{c}0.0 \\
8\end{array}$ & $\begin{array}{c}4.2 \\
4\end{array}$ & $\begin{array}{c}1.4 \\
7\end{array}$ & $\begin{array}{c}42 \\
3\end{array}$ & $\begin{array}{l}1 . \\
69\end{array}$ & $\begin{array}{l}2 \\
5 \\
1\end{array}$ & $\begin{array}{l}8 \\
7\end{array}$ \\
\hline AMT 92 & $\begin{array}{c}38.2 \\
89\end{array}$ & $\begin{array}{c}38.54 \\
1\end{array}$ & $\begin{array}{c}38 . \\
54 \\
0\end{array}$ & $\begin{array}{l}0 . \\
2 \\
5 \\
2\end{array}$ & $\begin{array}{l}1 \\
0 \\
0\end{array}$ & $\begin{array}{l}1 . \\
00\end{array}$ & $\begin{array}{c}0 . \\
1 \\
0\end{array}$ & $\begin{array}{l}92 \\
\text { TO }\end{array}$ & 53.9 & $\begin{array}{c}0.0 \\
3\end{array}$ & $\begin{array}{c}1.0 \\
5\end{array}$ & $\begin{array}{c}0.4 \\
8\end{array}$ & $\begin{array}{c}42 \\
5\end{array}$ & $\begin{array}{c}1 . \\
00\end{array}$ & $\begin{array}{l}1 \\
0 \\
5\end{array}$ & $\begin{array}{l}4 \\
8\end{array}$ \\
\hline AMT 93 & $\begin{array}{c}36.7 \\
32\end{array}$ & $\begin{array}{c}36.98 \\
3\end{array}$ & $\begin{array}{c}36 . \\
98 \\
2\end{array}$ & $\begin{array}{l}0 . \\
2 \\
5 \\
1\end{array}$ & $\begin{array}{l}1 \\
0 \\
0\end{array}$ & $\begin{array}{l}0 . \\
98\end{array}$ & $\begin{array}{l}0 . \\
0 \\
5\end{array}$ & $\begin{array}{l}93 \\
\text { TO }\end{array}$ & 40.3 & $\begin{array}{c}0.0 \\
4\end{array}$ & $\begin{array}{c}1.2 \\
1\end{array}$ & $\begin{array}{c}0.4 \\
4\end{array}$ & $\begin{array}{c}42 \\
8\end{array}$ & $\begin{array}{l}0 . \\
98\end{array}$ & $\begin{array}{l}1 \\
2 \\
3\end{array}$ & $\begin{array}{l}4 \\
5\end{array}$ \\
\hline AMT 94 & $\begin{array}{c}37.7 \\
30\end{array}$ & $\begin{array}{c}37.98 \\
4\end{array}$ & $\begin{array}{c}37 . \\
98 \\
0\end{array}$ & $\begin{array}{l}0 . \\
2 \\
5 \\
4\end{array}$ & $\begin{array}{l}9 \\
8\end{array}$ & $\begin{array}{l}0 . \\
85\end{array}$ & $\begin{array}{l}0 . \\
0 \\
6\end{array}$ & & & & & & & & & \\
\hline
\end{tabular}




\begin{tabular}{|c|c|c|c|c|c|c|c|c|c|c|c|c|c|c|c|c|}
\hline AMT 95 & $\begin{array}{c}38.6 \\
91\end{array}$ & $\begin{array}{c}38.94 \\
3\end{array}$ & $\begin{array}{c}38 . \\
94 \\
0\end{array}$ & $\begin{array}{l}2 \\
5 \\
2\end{array}$ & $\begin{array}{l}9 \\
9\end{array}$ & $\begin{array}{l}1 . \\
44\end{array}$ & $\begin{array}{l}0 . \\
0 \\
9\end{array}$ & $\begin{array}{l}95 \\
\text { TO }\end{array}$ & 60.5 & $\begin{array}{c}0.0 \\
6\end{array}$ & $\begin{array}{c}2.5 \\
8\end{array}$ & $\begin{array}{c}0.8 \\
5\end{array}$ & $\begin{array}{c}42 \\
7\end{array}$ & $\begin{array}{l}1 . \\
44\end{array}$ & $\begin{array}{l}1 \\
7 \\
9\end{array}$ & $\begin{array}{l}5 \\
9\end{array}$ \\
\hline AMT 51 & $\begin{array}{c}38.3 \\
19\end{array}$ & $\begin{array}{c}38.44 \\
4\end{array}$ & $\begin{array}{c}38 . \\
43 \\
8\end{array}$ & $\begin{array}{c}0 . \\
1 \\
2 \\
5\end{array}$ & $\begin{array}{l}9 \\
5\end{array}$ & $\begin{array}{l}2 . \\
21\end{array}$ & $\begin{array}{l}1 \\
1 . \\
6 \\
0\end{array}$ & & & & & & & & & \\
\hline
\end{tabular}

\begin{tabular}{|c|c|c|c|c|c|c|c|}
\hline $\begin{array}{c}\text { Sit } \\
\text { e }\end{array}$ & $\begin{array}{c}\text { Sample } \\
\mathrm{s}\end{array}$ & $\begin{array}{c}\mathrm{S} 1 \text { (mg HC/g } \\
\text { rock) }\end{array}$ & $\begin{array}{c}\mathrm{S} 2 \text { (mg HC/g } \\
\text { rock) }\end{array}$ & $\begin{array}{c}\mathrm{S} 3 \text { (mg CO2/g } \\
\text { rock) }\end{array}$ & $\begin{array}{c}\operatorname{Tmax}\left({ }^{\circ}\right. \\
\mathrm{C})\end{array}$ & $\begin{array}{l}\text { TOC } \\
(\%)\end{array}$ & $\begin{array}{c}\mathrm{HI}(\mathrm{mg} \mathrm{HC} / \mathrm{g} \\
\text { TOC) }\end{array}$ \\
\hline & 12 & 0.08 & 2.09 & 0.54 & 425 & 1.31 & 160 \\
\hline \multirow[t]{5}{*}{11} & 11 & 0.06 & 2.21 & 0.36 & 123 & 1.34 & 165 \\
\hline & 10 & 0.06 & 4.64 & 0.41 & 42. & 2.01 & 231 \\
\hline & 9 & 0.05 & 3.30 & 0.17 & 4.2 & 2.21 & 149 \\
\hline & 18 & 0.07 & 7.31 & 0.44 & 428 & 2.68 & 273 \\
\hline & 17 & 0.11 & 7.78 & 1. 10 & 427 & 3.19 & 244 \\
\hline \multirow[t]{5}{*}{12} & 16 & 0.07 & 3.54 & $0 . \%$ & 424 & 2.51 & 141 \\
\hline & 15 & 0.10 & 3.14 & 1.22 & 418 & 3.09 & 102 \\
\hline & 14 & 0.11 & 7.99 & 073 & 427 & 3.38 & 236 \\
\hline & 13 & 0.17 & 9.55 & 0.92 & 417 & 6.57 & 145 \\
\hline & 8 & 0.03 & 0.69 & 0.22 & 429 & 0.98 & 70 \\
\hline \multirow[t]{16}{*}{10} & 7 & & & & & & \\
\hline & 6 & & 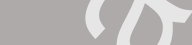 & & & & \\
\hline & 5 & 0.04 & 1. 5 & 0.15 & 430 & 1.16 & 142 \\
\hline & & & $\nabla$ & & & & \\
\hline & 48 & 0.13 & 4.99 & 1.64 & 420 & 4.24 & 118 \\
\hline & 49 & 0.03 & 2.86 & 0.20 & 430 & 1.94 & 147 \\
\hline & 50 & 0.26 & 11.28 & 1.95 & 420 & 6.95 & 162 \\
\hline & 51 & 0.05 & 4.47 & 0.11 & 427 & 2.43 & 184 \\
\hline & 52 & 0.06 & 1.86 & 0.94 & 424 & 1.53 & 122 \\
\hline & 54 & 0.04 & 2.82 & 0.38 & 432 & 1.00 & 282 \\
\hline & 55 & 0.05 & 9.26 & 0.76 & 429 & 3.05 & 304 \\
\hline & 58 & 0.06 & 7.36 & 0.30 & 429 & 2.37 & 311 \\
\hline & 59 & 0.08 & 9.87 & 0.82 & 431 & 2.75 & 359 \\
\hline & 60 & 0.04 & 6.15 & 0.49 & 426 & 2.30 & 267 \\
\hline & 61 & 0.06 & 7.90 & 0.31 & 427 & 2.76 & 286 \\
\hline & 62 & 0.07 & 10.18 & 0.25 & 428 & 3.03 & 336 \\
\hline \multicolumn{8}{|l|}{35} \\
\hline & 63 & 0.07 & 8.60 & 0.47 & 429 & 2.70 & 319 \\
\hline & 64 & 0.06 & 6.18 & 0.97 & 427 & 2.38 & 260 \\
\hline & 65 & 0.05 & 7.20 & 0.52 & 426 & 2.31 & 312 \\
\hline
\end{tabular}




\section{Journal Pre-proof}

\begin{tabular}{|c|c|c|c|c|c|c|c|}
\hline & 66 & 0.07 & 7.61 & 0.79 & 431 & 2.32 & 328 \\
\hline & 67 & 0.09 & 8.94 & 0.24 & 427 & 3.05 & 293 \\
\hline & 68 & 0.12 & 9.27 & 0.90 & 427 & 3.49 & 266 \\
\hline & 69 & 0.06 & 2.69 & 0.75 & 421 & 1.72 & 156 \\
\hline & 70 & 0.03 & 1.52 & 0.39 & 429 & 0.99 & 154 \\
\hline & 71 & 0.04 & 1.83 & 0.18 & 427 & 1.24 & 148 \\
\hline & & & & & & \\
\hline & 73 & 0.03 & 1.17 & 0.28 & 427 & 1.01 & 116 \\
\hline & 74 & 0.03 & 0.87 & 0.24 & 420 & 1.22 & 71 \\
\hline & 75 & 0.13 & 8.99 & 1.73 & 424 & 2.80 & 321 \\
\hline & 76 & 0.03 & 5.06 & 0.31 & 433 & 4.20 & 120 \\
\hline & 77 & 0.04 & 3.93 & 0.45 & 432 & 3.82 & 103 \\
\hline & 78 & 0.03 & 3.72 & 0.21 & -22 & 3.73 & 100 \\
\hline
\end{tabular}

\begin{tabular}{|l|l|l|l|l|l|l|l|}
\hline & 82 & 0.08 & 4.31 & 0.24 & +24 & 1.27 & 339 \\
\hline & 83 & 0.06 & 2.07 & 0.31 & 421 & 1.00 & 207 \\
\hline & 84 & 0.08 & 2.12 & 0.22 & 422 & 1.04 & 204 \\
\hline & 85 & 0.07 & 3.02 & 0.5 & 422 & 2.69 & 112 \\
\hline & 86 & 0.05 & 2.99 & 0.27 & 421 & 2.46 & 122 \\
\hline 37 & 87 & 0.22 & 5.89 & 1.5 & 428 & 2.50 & 236 \\
\hline & 88 & 0.06 & 3.27 & 0.65 & 425 & 2.84 & 115 \\
\hline & 89 & 0.04 & 1.16 & 0.56 & 426 & 2.05 & 57 \\
\hline & 90 & 0.04 & 1.63 & 0.7 & 425 & 1.83 & 89 \\
\hline & 91 & 0.08 & 4.24 & 1.41 & 423 & 1.69 & 251 \\
\hline
\end{tabular}

samples

\begin{tabular}{|c|c|}
\hline & TOC (\%) \\
\hline 1 & 1.31 \\
\hline 2 & 1.34 \\
\hline 3 & 2.01 \\
\hline 4 & 2.21 \\
\hline 5 & 2.68 \\
\hline 6 & 3.19 \\
\hline 7 & 2.51 \\
\hline 8 & 3.09 \\
\hline 9 & 3.38 \\
\hline 0 & 6.57 \\
\hline 1 & 0.98 \\
\hline 12 & 1.16 \\
\hline
\end{tabular}




\section{Plate I}

Acritarchs: Specimens are located according the sample number and the England finders coordinates. The diameter size is provided in $\mu \mathrm{m}$.

1. Maranhites brasiliensis Brito, 1965 emend Burjack and Oliveira 1989. Site 11, AM 12, 18K 224, D24/2, total diameter $125 \mu \mathrm{m}$

2. Maranhites lobulatus Burjack and Oliveira 1989, Site 11, AM 12, 18K 224, Q26, total diameter $145 \mu \mathrm{m}$

3. Maranhites stockmansii (Martin) Martin, 1984, Site 11, AM 1 2, 18K 224, Q26, total diameter $145 \mu \mathrm{m}$

4. Maranhites mosesii (= M. insulatus Burjack and Olivı:ra, 1989) (Sommer, 1956)

Brito,1967. Site 11, AM 12, 18K 224, E35/4, total dian. ter $120 \mu \mathrm{m}$

5. Petrovina connata Oliveira and Burjack, $19 \%$ ` ite 10 , AM $7,18 \mathrm{~K} 220$, K13/4, total diameter $145 \mu \mathrm{m}$, cells $45 \mu \mathrm{m}$.

6. Pterospermopsis crassimarginata L' 'rjack and Oliveira apud Oliveira, 2007, nomen nudum. Site 11, AM 12, 18K $224 \mathrm{D} 1 \mathrm{~J} / 2$, total diameter $45-50 \mu \mathrm{m}$

7. Crucidia camirense (Lobo 3ontia) Ottone, 1996, Site 10, AM 7, 18K 220, F16/3, total total lenght of the processes ¿n-`,5 $\mu \mathrm{m}$.

8. Pseudolunulidia maropunctata Brito and Quadros, 1984. Site 35, AM 68, 18L30, 77131, J44/2, central body width $41 \mu \mathrm{m}$.

9. Navifusa bacilla (Deunff) Playford, 1977 forma crescentis. Site 10, AM 7, 18K220, T42/4, width of central body $25 \mu \mathrm{m}$.

10. Disparifusa urariaensis Le Hérissé, 2013, nomen nudum, Site 11, AM 12, 18K224, N15/2, length $52 \mu \mathrm{m}$, width $22 \mu \mathrm{m}$.

11. Umbellasphaeridium deflandrei (Moreau-Benoit) Jardiné et al., 1972. Site 11, AM 10, 18K 223, L31/2, total diameter $38 \mu \mathrm{m}$ 
12, 13. Horologinella quadrispina Jardiné, et al., 1972. 12. Site 11, AM 9, 18K 222, H17/4, central body 45x50 $\mu \mathrm{m}$, process length 6-10 $\mu \mathrm{m}$. 13, Site 35, AM 78, 18L33, 77146, G29, central body $42 \times 24 \mu \mathrm{m}$, process length $14.5 \mu \mathrm{m}$

14-16. Duvernaysphaera cruciformis Le Hérissé, 2001, nomen nudum sp. nov.sp.14. Paratype, site 35, AM 58, 18L27, 77116, S36, central body $30 \mu \mathrm{m}$, flange 5,6 $\mu \mathrm{m} ; 15$. Paratype, site 35, AM 58, 18L27, 77116, P32, central body $36 \mu \mathrm{m}$, flange $3 \mu \mathrm{m}$; 16. Holotype, site 35, AM 76, 18L32, 77141, Q28, central body $36 \mu \mathrm{m}$, flange $6,7 \mu \mathrm{m}$ 17. Duvernaysphaera angelae (=D. tessella) Deunff, 1964. Site 11, AM 12, 18K224, Q38/3, Total diameter $45 \mu \mathrm{m}$.

\section{Plate II}

Acritarchs: Specimens are located according th a $\_$m ple number and the England finders coordinates. The diameter size is provid $\mathrm{d}$ ir $\mu \mathrm{m}$.

1. Mediocorpore conspicuus Burjack `nd Oliveira apud Oliveira, 1997, nomen nudum. Site

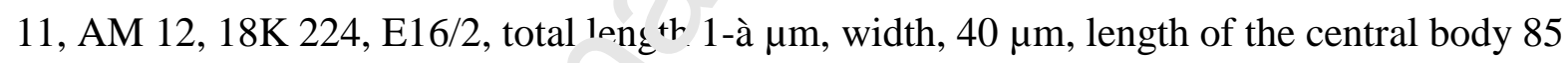
$\mu \mathrm{m}$.

2. Duvernaysphaera radian F, rito, 1967a. Site 11, AM 12, 18K 224, M43/3, total diameter $140 \mu \mathrm{m}$.

3. Puteoscortum williereae Martin, 1981. Site 35, AM 78, 77148, C40/3, CC $42 \mu \mathrm{m}, \mathrm{LP} 21$ $\mu \mathrm{m}$

4. Advenasphaeridium australis Burjack and Oliveira 1997, nomen nudum. Site 11, AM 11, 18K 223, H43/2, central body $39 \mu \mathrm{m}, \mathrm{Lp} 33 \mu \mathrm{m}$

5. Puteoscortum williereae Martin, 1981. Site 37, AM 89, 77163, S41, CC $33 \mu \mathrm{m}, \mathrm{Lp} 22$ $\mu \mathrm{m}$ 
6. Leiofusa bisubulata Brito and Quadros, 1984. Site 35, AM 68, 77133, Q 29/4, central body $35 x 156 \mu \mathrm{m}$, Lp $56 \mu \mathrm{m}$.

7-9. ?Chomotriletes sp. A. 7. Site 11 , AM 9, $18 \mathrm{~K} 222$, J13/4, total diameter $56 \mu \mathrm{m}$. 8. Site 37 , AM 85, 77151, P15, total diameter $31 \mu \mathrm{m}$; 9. Site 37, AM 85, 77151, N32 Total diameter 50 $\mu \mathrm{m}$.

10. Unellium ampullium Wicander, 1974. Site 11, AM 12, $18 \mathrm{~K} 224$, V28/2, central body 18 $\mu \mathrm{m}$, process length $20 \mu \mathrm{m}$.

11. Diaphorochroa gracile Burjack and Oliveira apud Oliveira 1y,7, nomen nudum. Site 35, AM 65, 77126, M43, CC $40 \mu \mathrm{m}, \mathrm{LP} 18 \mu \mathrm{m}$

12. Naevisphaeridium sprucegrovense (Staplin, 1961) nov. comb. Site 35, AM 65, 77126, 039/4, CC $28 \mu \mathrm{m}, \mathrm{LP} 12 \mu \mathrm{m}$

13. Naevisphaeridium desiderata (Burjack anr! 'L'iv ira apud Oliveira, 1997) nomen nudum nov comb. Site 37, AM 85, 77151, H36/. C ntral body $31 \mu \mathrm{m}, \mathrm{Lp} 11 \mu \mathrm{m}$

14. Puteoscortum limai Burjack and Giv veira apud Oliveira, 1997. Site 11, AM 11, 18K 223, P25/4, central body $48 \mu \mathrm{m}$, Lp $22: \cdot \mathrm{m}$

15. Stellinium micropolygonalc 'Stockmans and Willière) Playford 1977. Site 10, AM 7 , 18K220, F14/4, central body 32 Lp $48 \mu \mathrm{m}$

16. Estiastra spinireticu' $\imath$ ' Oliveira and Burjack, 1997. Site 35, AM 78, 77146, U33/4, CC $33 \mu \mathrm{m}, \mathrm{LP} 10 \mu \mathrm{m}$

17. Veryhachium capitata Le Hérissé, 2001 nomen nudum . Site 35, AM 75, 77136, J42/3, CC $22 \mu \mathrm{m}, \mathrm{LP} 9 \mu \mathrm{m}$.

18. Veryhachium insanum Le Hérissé, 2001, nomen nudum. Site 35, AM 78, 77146, U33/4, CC $24.5 \mu \mathrm{m}, \mathrm{LP} 9 \mu \mathrm{m}$

19. Tinacula simplex Quadros, 1999 Site 35, AM 58, 18L27, 77118, R39, length $89 \mu \mathrm{m}$, maximum width $54 \mu \mathrm{m}$ 
20. Bipolarisvelata accreta Burjack and Oliveira apud Oliveira, 1997, nomen nudum.Site 11, AM 12, 18K 224, E26, central body 55x35 $\mu \mathrm{m}$, polar filamentous projections 50-65 $\mu \mathrm{m}$ long.

\section{Plate III}

Chitinozoans: Specimens are located according the sample number and the England finders coordinates. The scale bar is annoted in $\mu \mathrm{m}$.

1, 2. Angocitina avelinoi (Lange 1952). Site 11, AM11 15, O22/0; AM11 15, R30/3.

3, 4. Angochitina mourai (Lange 1952). Site 35, Am49 40, C37/(), Am58 50, M23/0.

5, 6. Angochitina mourai long neck variant sensu Grahn ar « ^eı 2005. Site 37, Am85 85, H14/4; AM 5850 U23/4.

7, 8. Angochitina sp.C? Grahn and Melo 2005. Site 37, . M89 95, X14/4; AM89 95, M17/3.

9, 10. Fungochitina microspinosa Grahn and Me: ᄀ J05. Site 37, AM89 95, M17/2; AM65 60, W24/0.

\section{Plate IV}

Chitinozoans: Specimens are li ateci according the sample number and the England finders coordinates. The scale bar is . $n r$ oted in $\mu \mathrm{m}$.

1, 2. Fungochitina pilos ‘? (collinson and Scott 1958). Site 35, AM65 60, C29/0; AM82 $55, \mathrm{~K} 17 / 2$.

3, 4. Lagenochitina sommeri (Lange 1952). Site 11, AM9 11, J25/3; AM89 95, U29/0. 5, 6. Lagenochitina sp.A Grahn and Melo 2005. Site 37 AM89 95, O24/0; AM11 15, K27/1.

\section{Plate V}

Miospores: Specimens are located according the sample number and the England finders coordinates. The scale bar is annoted in $\mu \mathrm{m}$. 
1-3. Acinosporites acanthomammillatus Richardson, 1965. 1 : Site 10 Am7 2, K19/2 ; 2 : Site 10 Am7 2, M21/0 ; Site 11 Am9 10, D17/3.

4-6. Acinosporites eumammillatus Loboziak et al., 1988. 4 : Site 10 Am7 2, Q17/3 ; 5 : Site 10 Am7 2, D17/1/3; Site 10 Am7 2, K23/0.

7-9. Acinosporites lindlarensis Riegel, 1968. 7 : Site 35 Am89 96 O15/3 ; 8 : Site 35 Am89 96 A, Q20/2 ; Site 35 Am89 96 B Q20/2.

10. Ancyrospora langii (Taugourdeau-Lantz) Allen, 1965. Site 35 Am65 60, G23/1.

11. Ancyrospora simplex Guennel, 1963. Site 35 Am76 75, W78/'2.

\section{Plate VI}

Miospores: Specimens are located according the sample number and the England finders coordinates. The scale bar is annoted in $\mu \mathrm{m}$.

1-3. Ancyrospora sp. 1.1 : Site 35 Am 6. $6 r$, V18/2; 2 : Site 35 Am75 70, F34/1 ; 3 : Site 35 Am75 70, F34/1.

4-5. Aneurospora gregsii Aneurosnorı ‘reggsii (McGregor) Streel, 1974. 4 : Site 10 Am8 6, N15/2 ; 5 : Site 11 Am9 10, T1' '/2.

6-7. Apiculiretusispora sp. 6 . Ste 10 Am7 2, K18/1; 7 : Site 10 Am7 2, N16/1-3.

8. Archaeozonotriletes _n. nim $6865, \mathrm{U} 23 / 1$.

9-11. Archaeozonotriletes variabilis Naumova, 1953. 9: Site 11 Am7 2, E17/0 ; 10 : Site 11 Am9 10, V19/4 ; 11 : site 11 Am9 10, G22/0.

12. Auroraspora sp. Site 11 Am8 6, T18/0.

\section{Plate VII}

Miospores: Specimens are located according the sample number and the England finders coordinates. The scale bar is annoted in $\mu \mathrm{m}$. 
1-3. Auroraspora macra Sullivan, 1968. 1 : Site 10 Am7 2, V17/2 ; 2 : Site 10 Am7 2, R19/3$4 ; 3$ : Site $10 \operatorname{Am} 7$ 2, C23/2.

4-5. Camarozonotriletes concavus Loboziak et Streel, 1988. 4 : Site 10 Am7 2, O24/4 ; 5 : Site 35 Am89 95, M19/0.

6, 9. Chelinospora concinna Allen, 1965. Two different foci on the same specimen ; Site 10 Am7 2, V19/3B.

7-9. Chelinospora paravermiculata Loboziak et al., 1988. 8 : site 11 Am 9 10, N18/0 ; 9 : site 35 Am 89 96, V20/0.

10. Chelinospora sp. Site 10 Am8 6, D16/3.

11-12. Corystisporites corystus Richardson, 1965. 11 : sil 35 Am68 65, T26/2 ; 12 : site 35 Am85 85, 732-895.

\section{Plate VIII}

Miospores: Specimens are located acco - ding the sample number and the England finders coordinates. The scale bar is annotad i. $\mathrm{m}$.

1. Cymbosporites catillus Ali: $\eta$, 1у65. Site 10, Am8 6, K27/3.

2. Cymbosporites cyathus \& 1/e 1,1965 . Site 10, Am8 6, U19/3.

3-6. Cymbosporites $m a_{\delta}{ }^{n} \eta u c u s$ (McGregor) McGregor and Camfield 1982. 3 : Site 10 Am7 2, R16/0 ; 4 : Site 10, Am 7 2, T16/3 ; 5 : Site 10, Am8 6, W23/0 ; 6 : Site 11, Am9 10, J16/3. 7. Cyrtospora sp. Site 10, Am 7 K18/1-3.

8-9. Cyrtospora tumida Breuer and Steemans 2013. Site 10, Am8 6, M22/1; Site 10 Am8 6, M26/0.

10. Diatomozononotriletes franfklinii McGregor and Camfield 1982. Site 10 Am 7 2, 017/2.

11-12. Dibolisporites sp. 1.11 : Site 10 Am7 2, R22/3 ; 12 : Site 11, Am9 10, H17/0. 


\section{Plate IX}

Miospores: Specimens are located according the sample number and the England finders coordinates. The scale bar is annoted in $\mu \mathrm{m}$.

1. Dibolisporites sp. 1. Am78 80, W32-0.

2. Emphanisporites rotatus McGregor emend. McGregor, 1973. Site 10, Am7 2, N21/3.

3-4.Geminospora convoluta Breuer and Steemans, 2013. 3: Site 10 Am7 2, M23/4; 4 : site 37, Am89 95, F24/4.

5-6. Geminospora lemurata Balme emend. Playford, 1983. 5 : Cite 1 0, Am7 2, X16/2 ; 6 : Site 10, Am 7 2, B17/0.

7-8. Geminospora macromanifesta (Naumova) Arkhanoe. ka 1953. 7 : Site 35, Am76 75, N28/3 ; 8 : Site 37 Am 88 90, O28/0.

\section{Plate X}

Miospores: Specimens are located acco. - ling the sample number and the England finders coordinates. The scale bar is annotod i v.lm.

1-3.Geminospora punctata Ow 'ns, i971. 1 : Site 10, Am8 6, K16/0 ; 2 : Site 10, Am8 6, Q20/3; $3:$ Site 10, Am7 2. + 16/3.

4-5. Grandispora gabes 'nsis Loboziak and Streel, 1989. 4 : Site 37, Am89 95, X22/1-3 ; 5 : Site 37 Am89 95, Q19/0.

6-7. Grandispora libyensis Moreau-Benoit, 1980. 6 : Site 35, Am58 50, M26/0 ; 7: Site 35, Am62 55, U24/0.

\section{Plate XI}

Miospores: Specimens are located according the sample number and the England finders coordinates. The scale bar is annoted in $\mu \mathrm{m}$. 
1-2. Grandispora naumovae (Kedo) McGregor, 1973. 1: Site 37 Am85 85, Q29/0 ; 2 : Site 12, Am17 35, V20/0.

3-4. Grandispora permulta (Daemon) Loboziak et al. 1999. 3 : Site 10, Am8 6, M19/0 ; 4 : Site 37, Am89 96, V17/0.

5-6. cf. Grandispora sp . 1.5 : Site 35 Am68 65, T18/0 ; 6 : Site 37, Am89 95, L27/4.

\section{PI. XII}

Miospores: Specimens are located according the sample number and the England finders coordinates. The scale bar is annoted in $\mu \mathrm{m}$.

1-2. Grandispora sp. 2.1 : Site 37, Am89 95, N14/0 ; ? : ¿ite 35, Am65 60, Q15/3.

3. Grandispora sp.3. Site 35, Am76 75 ; P20/0.

4-5. Grandispora sp. 4.4 : Site 35, Am 76 75, F־)/ ; ; Site 35, Am75 70, L35/3.

6. Grandispora sp. A in Loboziak et al., 98. Site 3, Am88 90, V20-3.

\section{PI. XIII}

Miospores: Specimens are loca ad according the sample number and the England finders coordinates. The scale bar is . nr oted in $\mu \mathrm{m}$.

1-2. Grandispora tabuı ${ }^{+} \chi$ Loboziak and Streel, 1988. 1 : Site 37, Am89 96, X17/2; 2 : Site 10, $\operatorname{Am} 72, \mathrm{~B} 21 / 3$.

3. Incertae sedis. Site 35, Am78 $80 ; \mathrm{P} 19 / 0$.

4. Grandispora velata (Richardson) McGregor, 1973. Site 35, Am85 85, X31/3.

5. Hystricosporites sp. Site 35, Am58 50, V25/0.

6. Knoxisporites dedaleus (Naumova) Streel, 1977. Site 10, Am7 2, G16/4.

7-8. Lophozonotriletes dentatus Hughes and Playford, 1961. 7: Site 10 Am7 2, S22/3 ; 8 :

Site 10, Am8 6, T16/1. 
9-10. Lophozonotriletes media Taugourdeau-Lantz, 1967. 9; Site 10 Am7 2, L16/0 ; 10 :

$\mathrm{H} 16 / 2$.

11. Lopozonotriletes sp. Site 10, Am 86 ; Q15/4.

\section{Pl. XIV}

Miospores: Specimens are located according the sample number and the England finders coordinates. The scale bar is annoted in $\mu \mathrm{m}$.

1-4 n. g. n. sp. 1: site 35, Am19 4, V20/0 ; 2 : Site 11, Am9 10 V ᄂ $/ 0$; 3 : Site 11, Am9 10, $\mathrm{X} 22 / 3$; 4 : Site 11, Am9 $10, \mathrm{P} 16 / 0$.

5. Raistirickia sp. A in Richardson 1965: Site 11, Am9 1ヶ, Q18/2.

6. Retusotriletes sp. Site 10, Am7 2, J21/2.

7-8. Rugospora cf. Rugospora bricei in Loboz an an $\perp$ Streel, 1988: Site 10, Am7 2, B19/0 ;

8 : Site 10, Am7 2, O18/36.

9. Samarisporites sp., Site 10, Am7 2, : 19/3.

10-12. Samarisporites sp. C in Lohnzi ve et al. 1983. 10 : Site 10, Am7 2, T16/3 ; 11 : Site 10, Am 7 2, 12, V24/1; Site 11, A. 99 1v, O17/2.

\section{PI. XV}

Miospores: Specimens are located according the sample number and the England finders coordinates. The scale bar is annoted in $\mu \mathrm{m}$.

1-3. Samarisporites triangulatus Allen, 1965. 1 : Site 10, Am8 6, X21/2 ; 2 : Site 11, Site 11, Am9 10, Q22/1 ; 3 : Site 10, Am7 2 ; G21/0.

4-6. Verrucosisporites bulliferus Richardson et Mc Gregor, 1986.4 : Site 10, Am7 2, V16/4 ; 5 : Site 37, Am89 96 ; V17/1; 6 : Site 7, Am 8 6, G27/4. 
7-9. Verrucosisporites premnus-scurrus Morphon Breuer and Steemans, 2013.7 : Site 10,

Am7 2, B17/1-3 ; 8 : Site 11, Am9 10, N18/3 ; Site 10, Am7 2, S18/3.

\section{Highlights}

- Miospores, acritarchs and chitinozoans are relatively abundant and well preserved

- Palynomorphs provide a concordant age corresponding to the mid-Frasnian

- Miospores are correlated with the conodont biostratigraphic scale from the Boulonnais

- Palynomorphs are characteristic of the Gondwana and more precisely from Brazil

- Effective generation of hydrocarbon is dependent of the igneous effect 
Figure 1
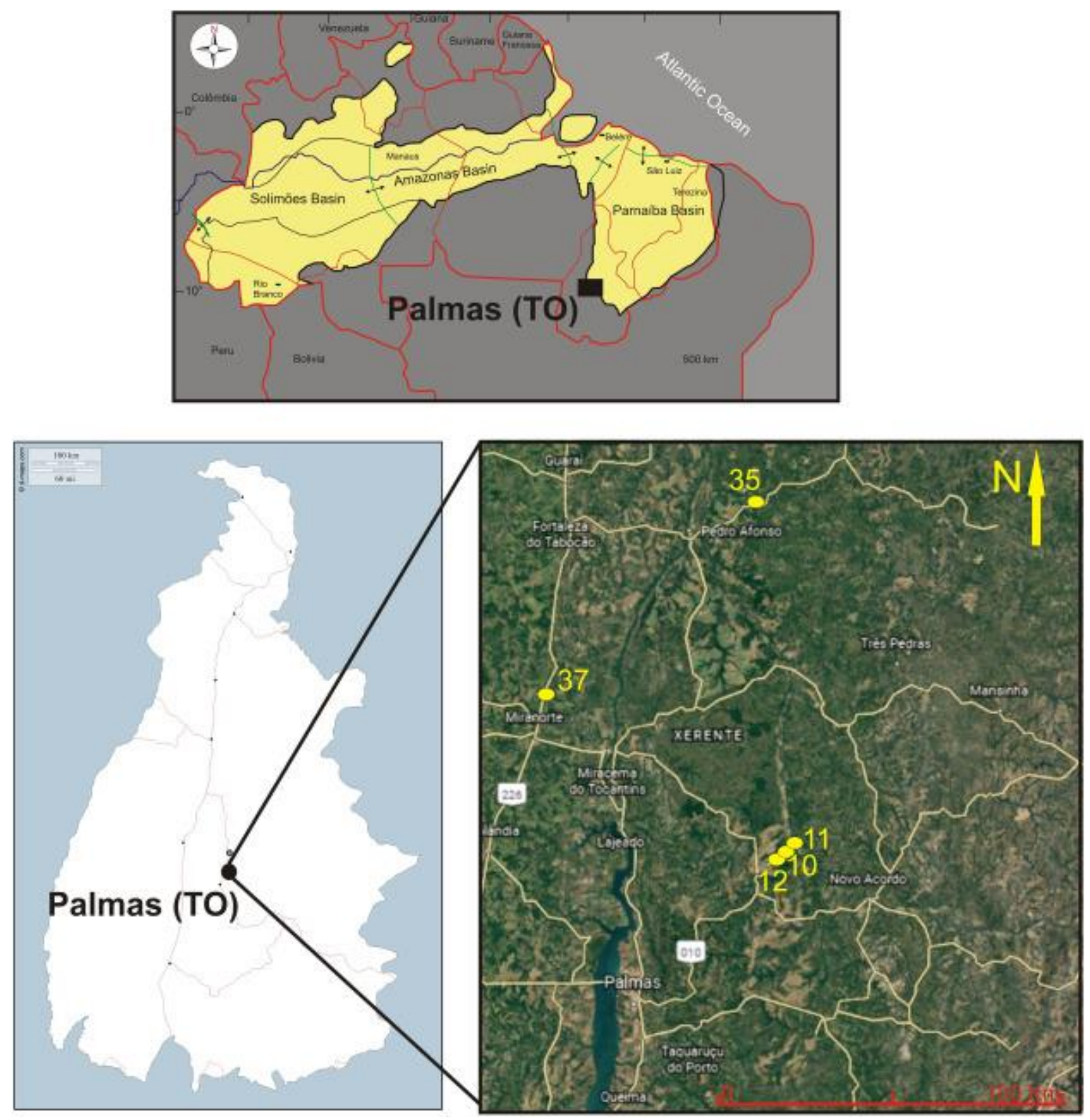

Figure 2 


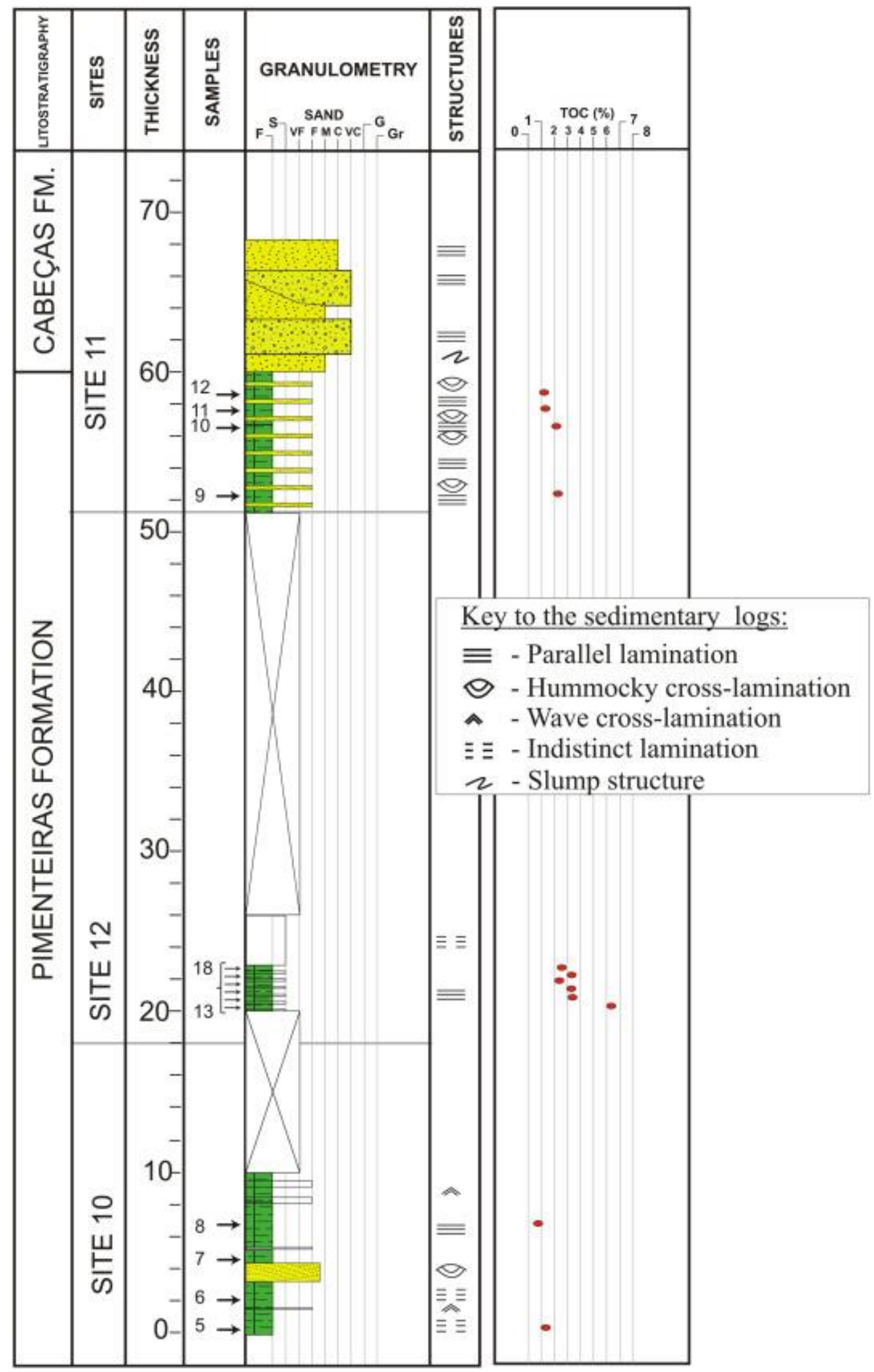

Figure 3 


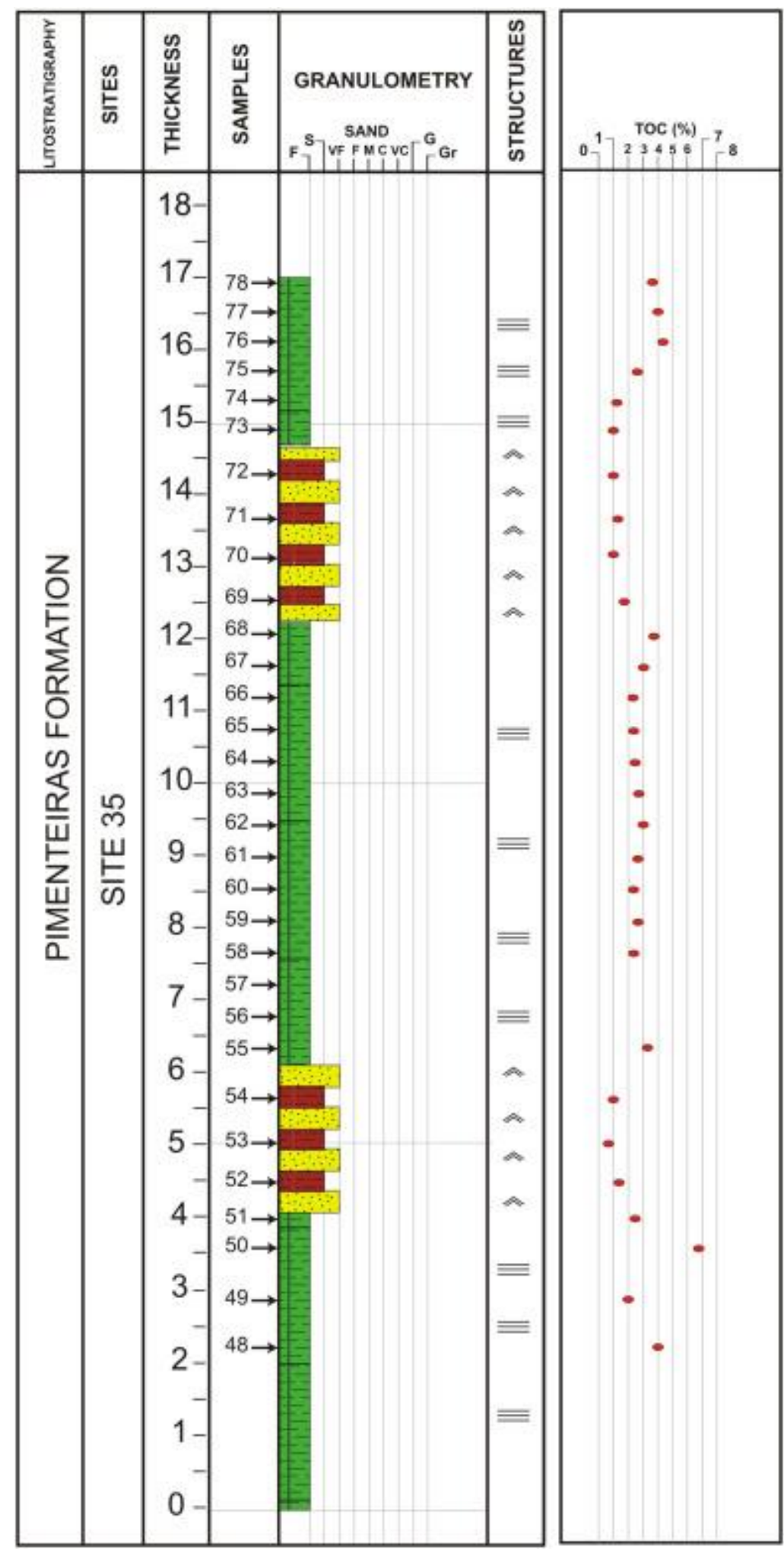

Figure 4 


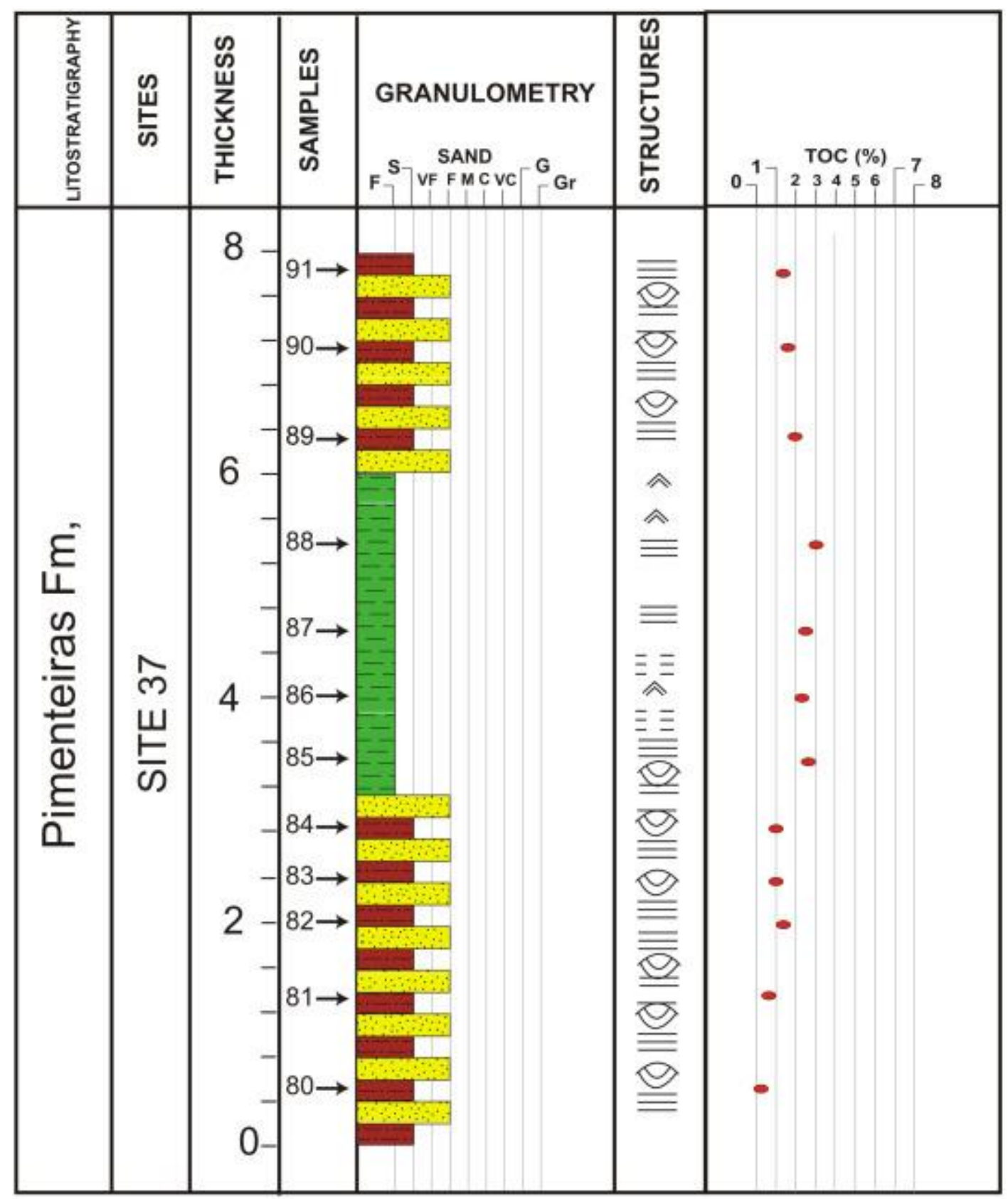

Figure 5 


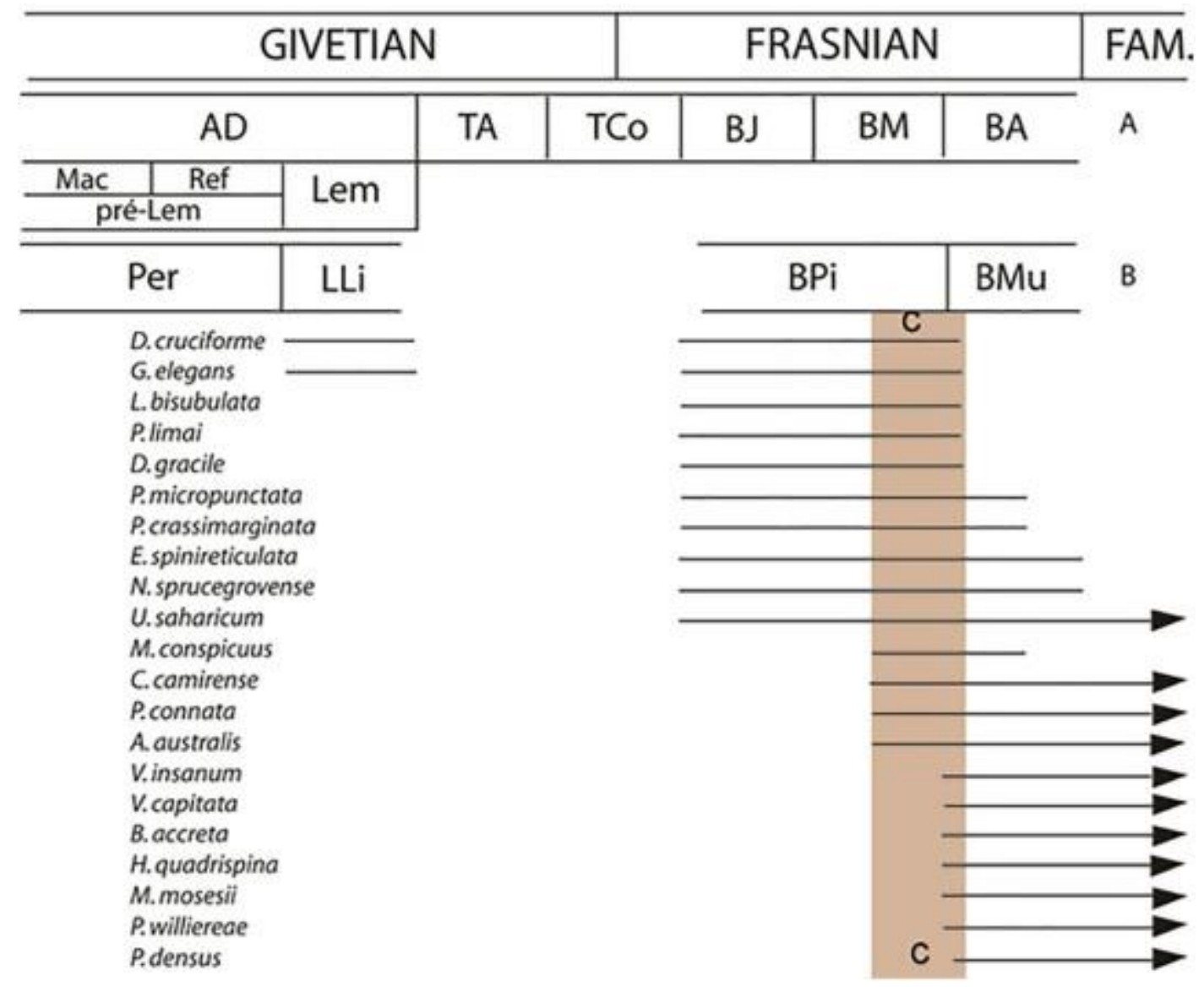

Figure 6

\begin{tabular}{|c|c|c|c|c|c|c|c|c|}
\hline \multicolumn{4}{|c|}{ GIVETIAN } & & \multicolumn{3}{|c|}{ FRASNIAN } & \\
\hline \multicolumn{3}{|c|}{ AD } & TA & TCo & BJ & B & & BA \\
\hline Mac & Ref & \multirow{2}{*}{ Lem } & & & & & & \\
\hline \multicolumn{2}{|c|}{ préLem } & & & & & & & \\
\hline \multicolumn{2}{|c|}{ Per } & LLi & & & \multicolumn{2}{|c|}{$\mathrm{BPi}$} & & $\mathrm{BMu}$ \\
\hline $\begin{array}{l}\text { A. lind } \\
\text { A. mas } \\
\text { C. con }\end{array}$ & sis & & & & & $-?$ & C & \\
\hline \multicolumn{3}{|c|}{ c. paravermiculata } & & & & & & \\
\hline \multicolumn{3}{|c|}{ G. lemurata } & & & & & & \\
\hline \multicolumn{9}{|c|}{ G. tabelata } \\
\hline \multicolumn{9}{|c|}{$\begin{array}{l}G \text { tabulata } \\
L \text { moda }\end{array}$} \\
\hline \multicolumn{9}{|c|}{$R$. bnicel } \\
\hline \multicolumn{9}{|c|}{ Samanispontes sp. C } \\
\hline \multicolumn{3}{|c|}{$V$ buflfons } & & & & & $\Rightarrow$ ? & \\
\hline \multicolumn{3}{|c|}{ A. eumammillatus } & & & & & 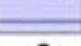 & \\
\hline
\end{tabular}


Plate I.
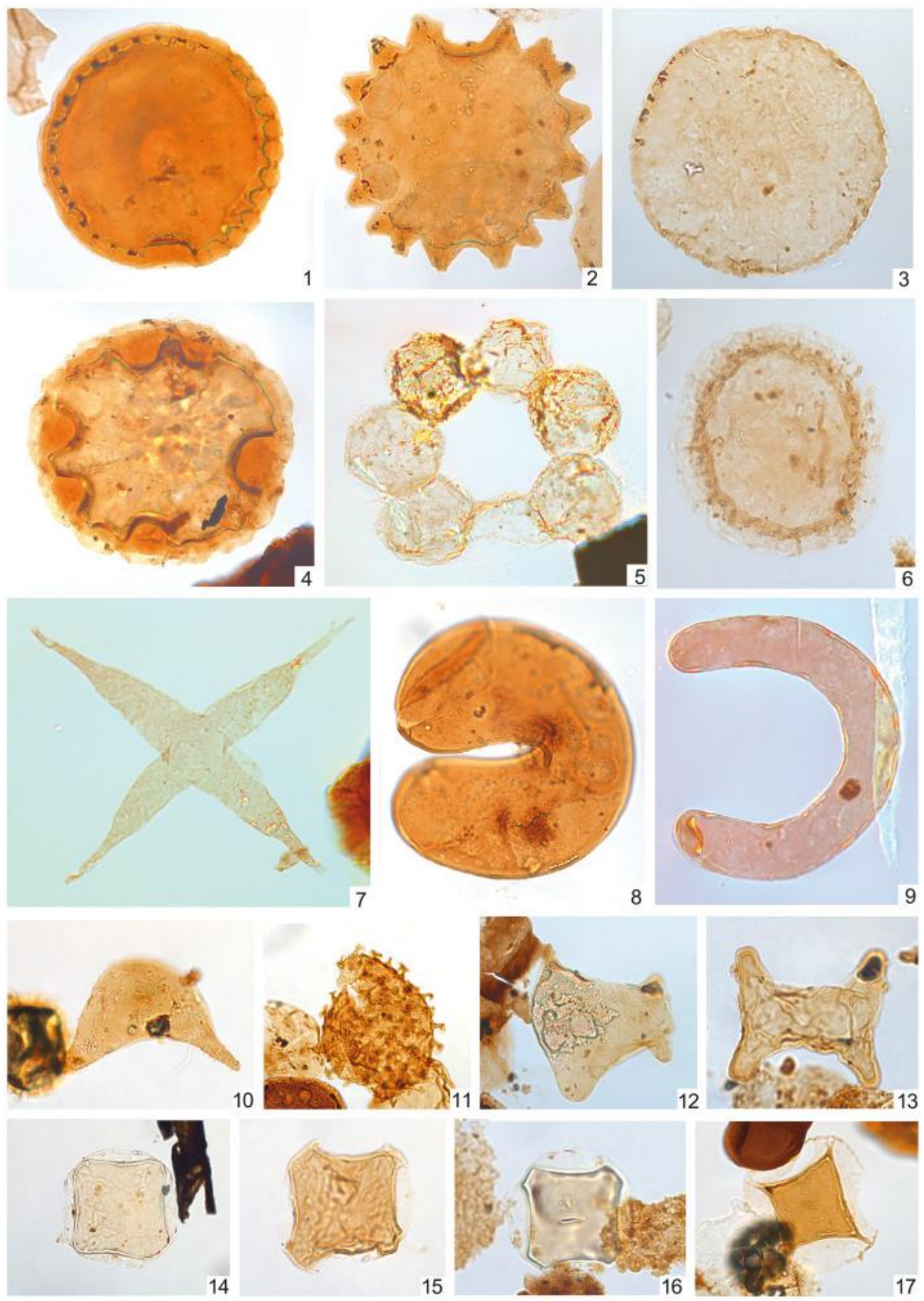
Plate II.

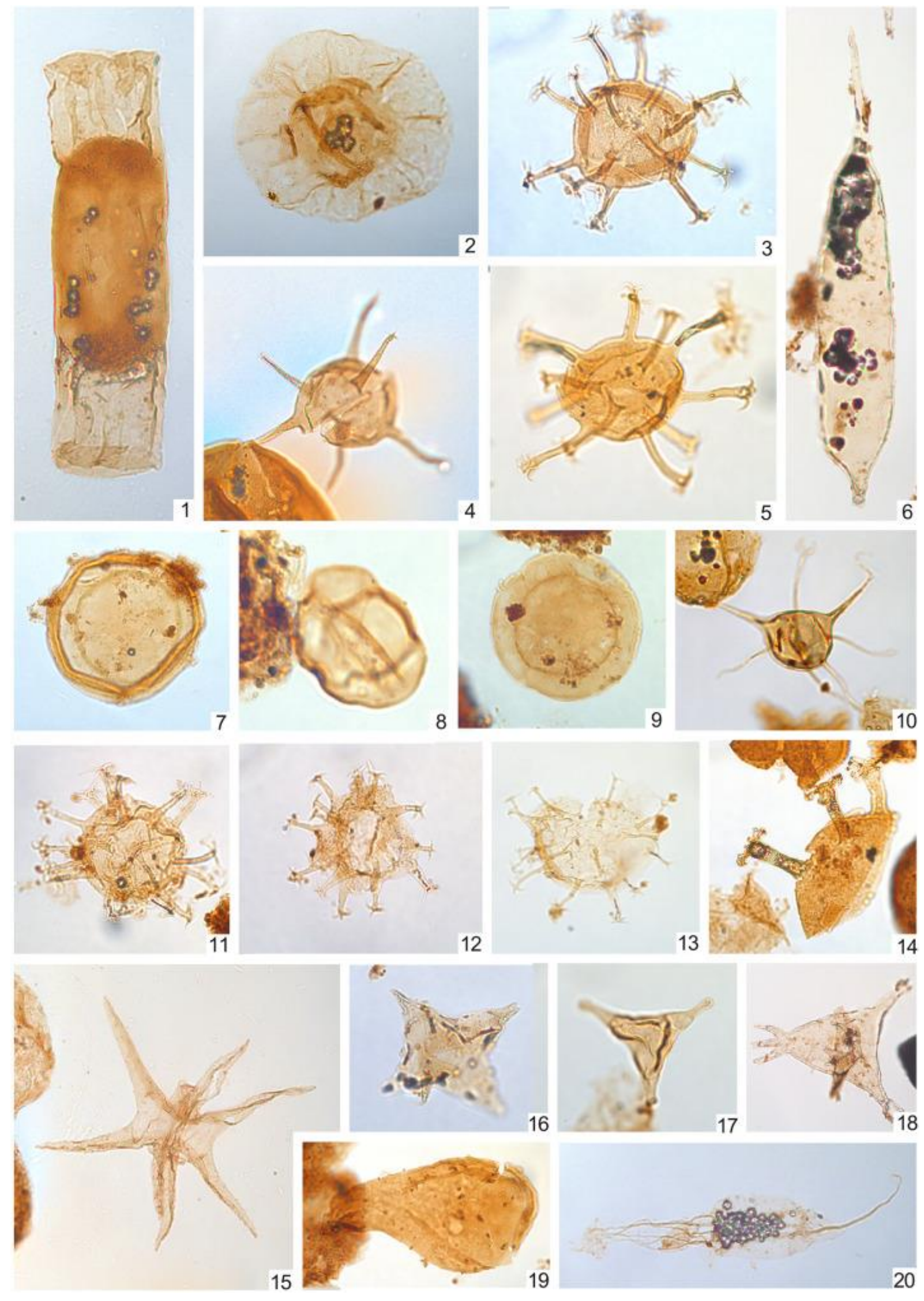


Plate III.

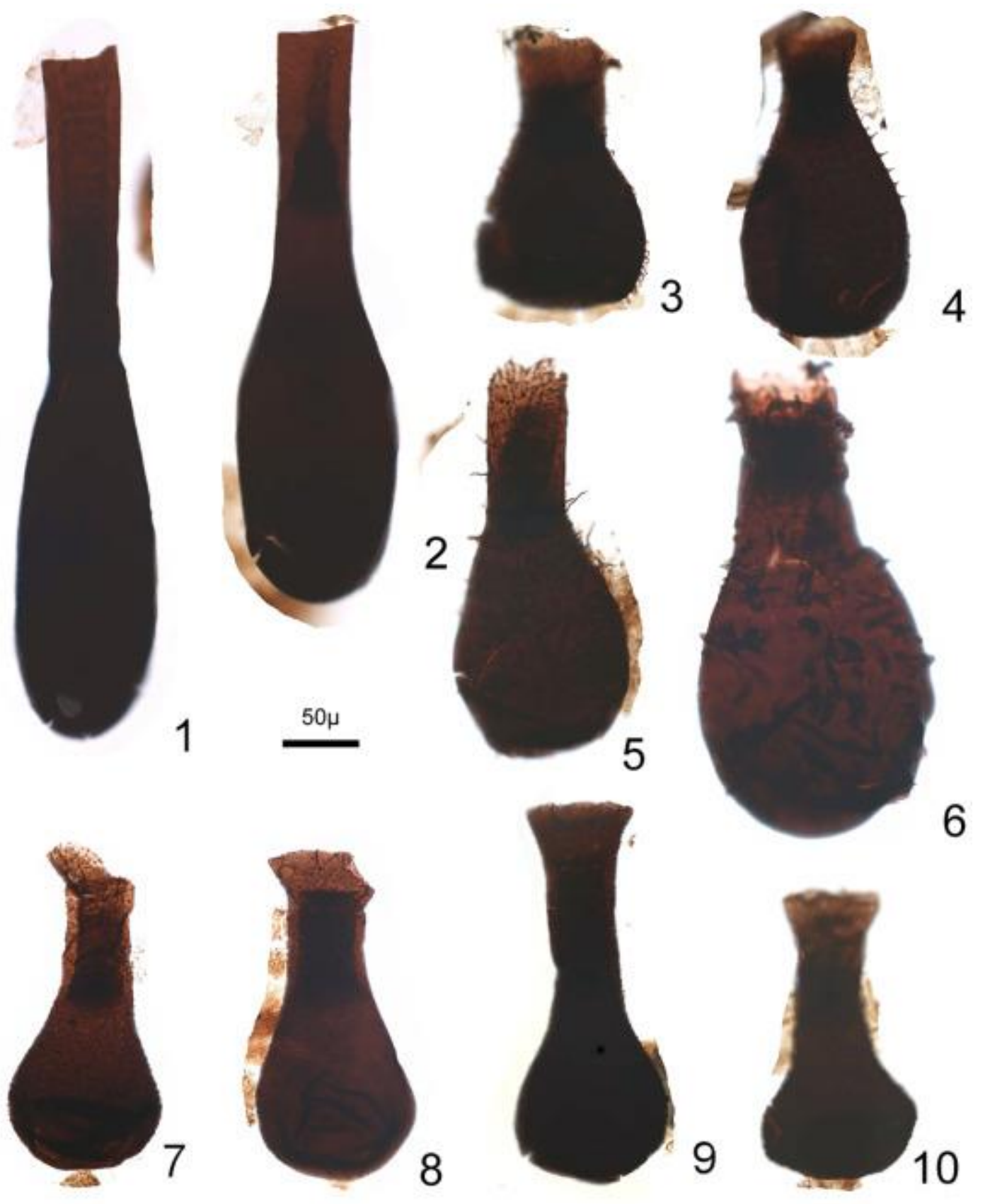




$$
\text { 11 }
$$


Plate V.

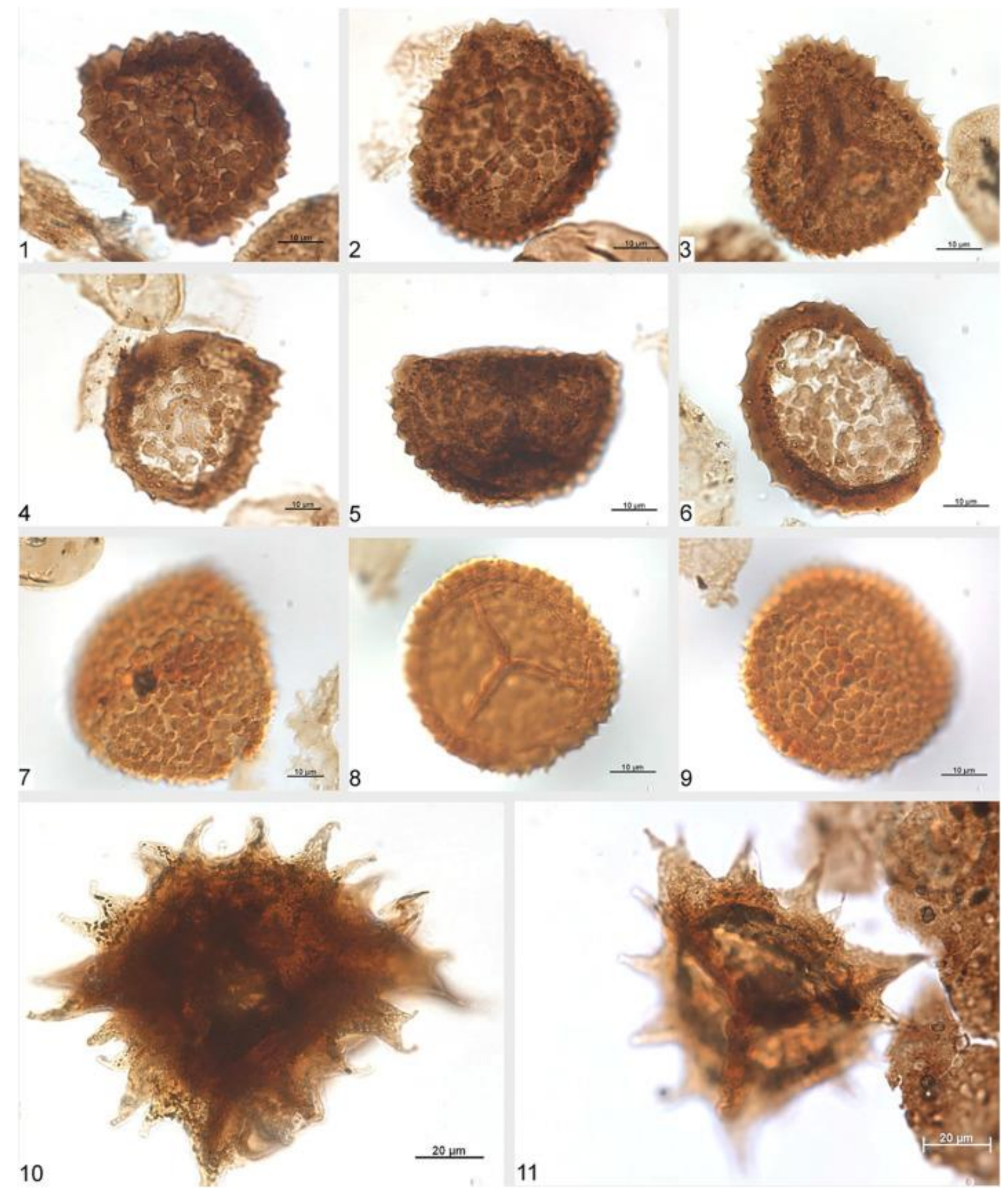


Plate VI.

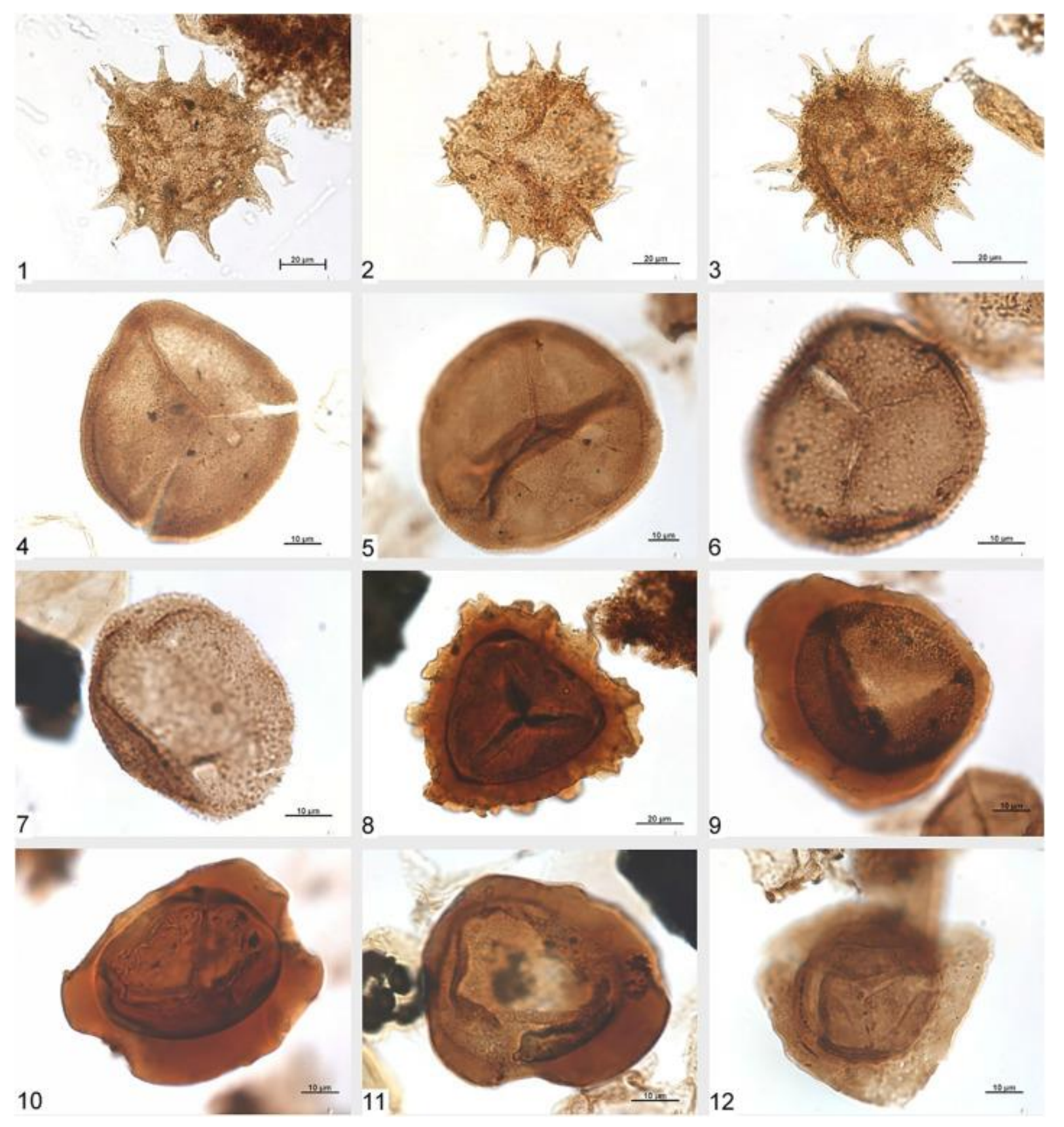


Plate VII.

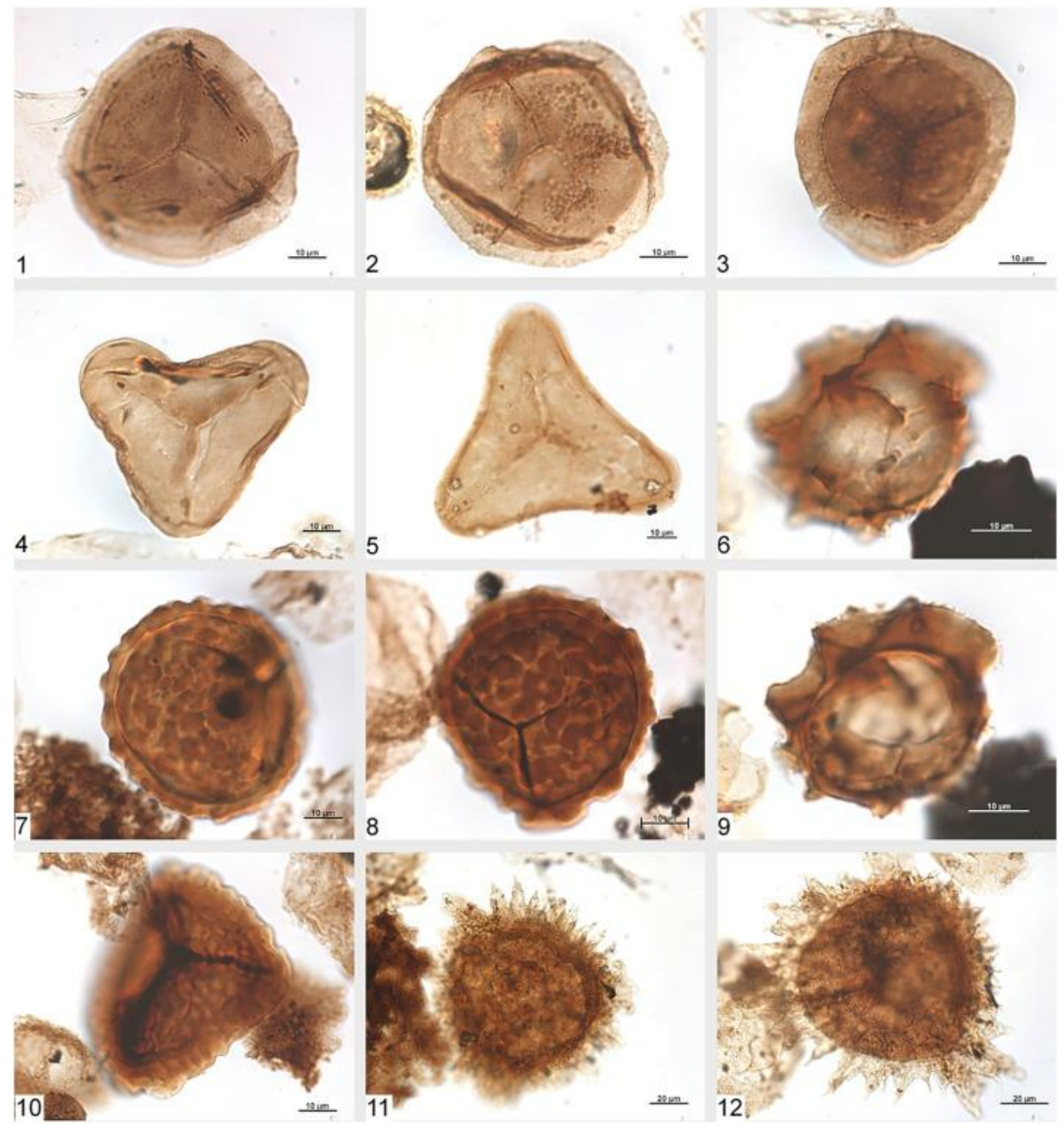


Plate VIII.

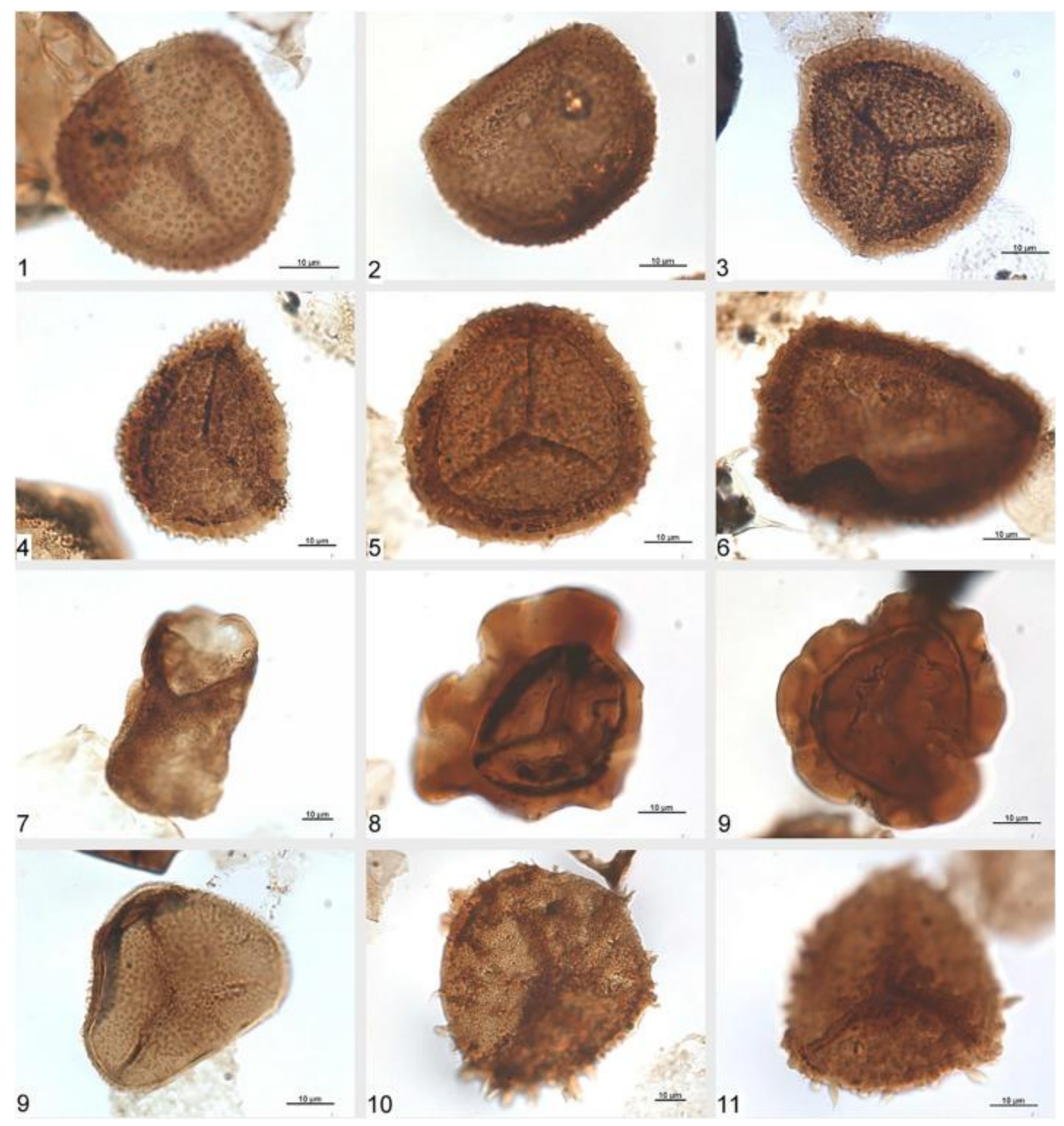


Plate IX.

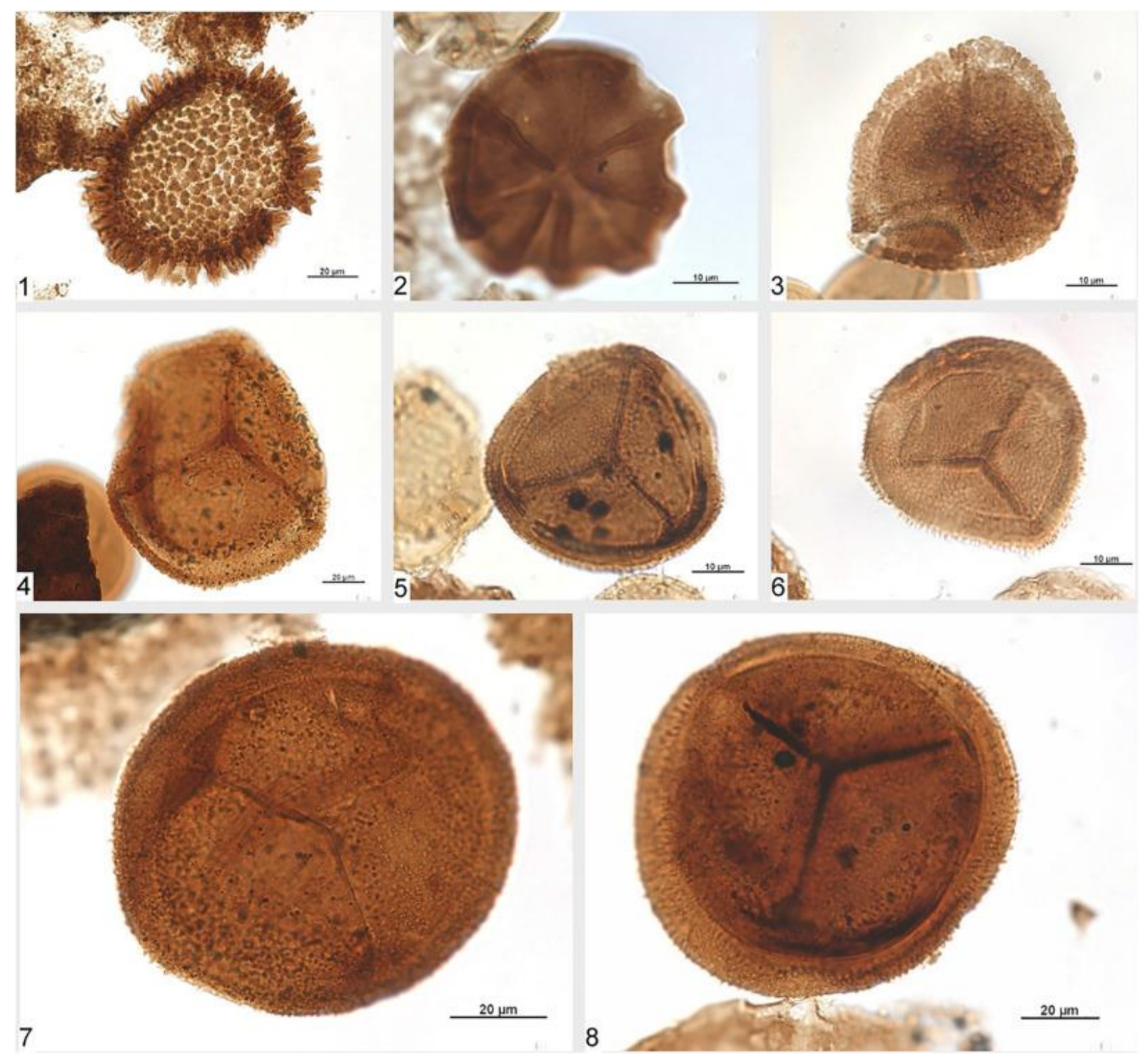


Plate X.

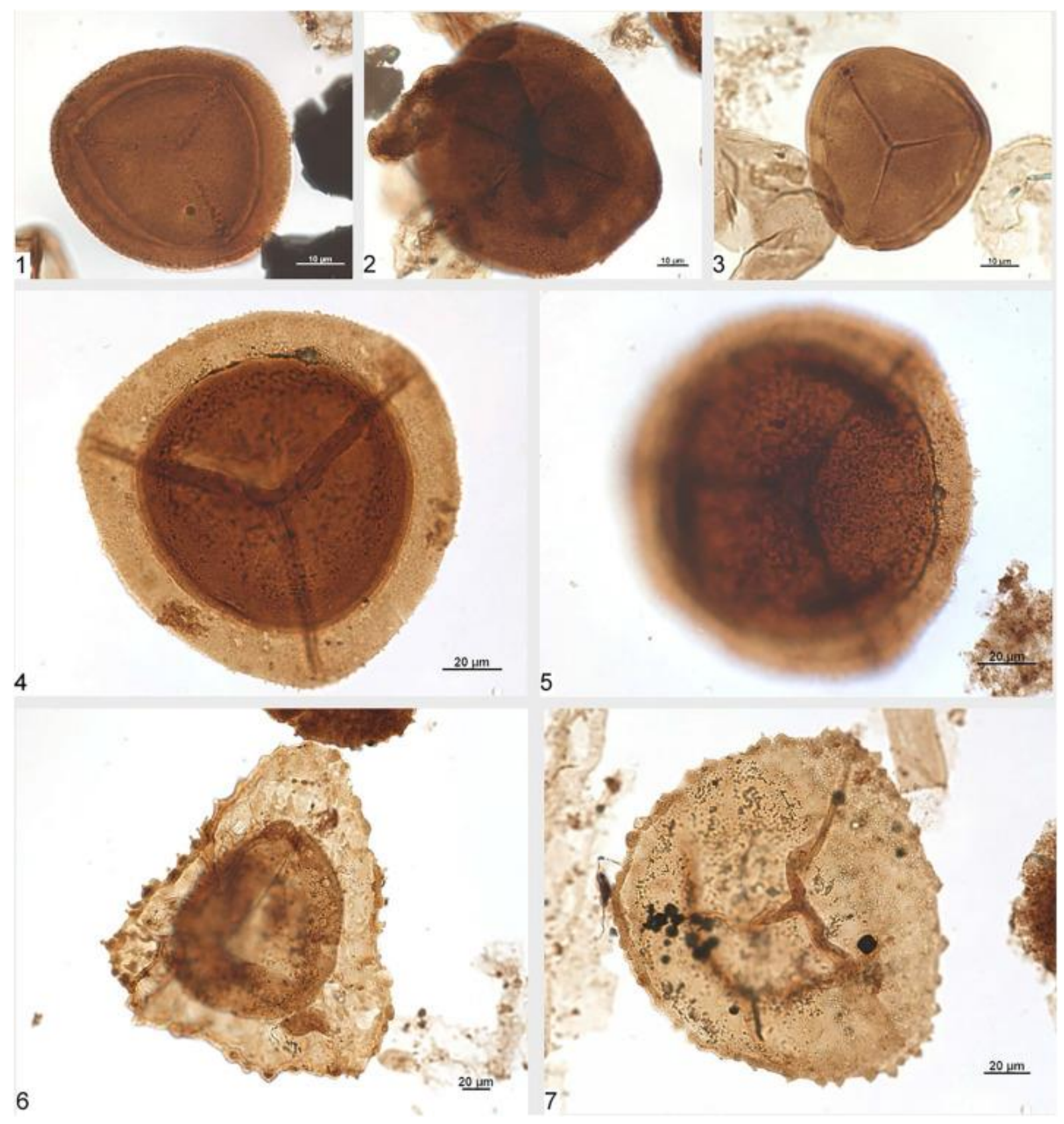


Plate XI.

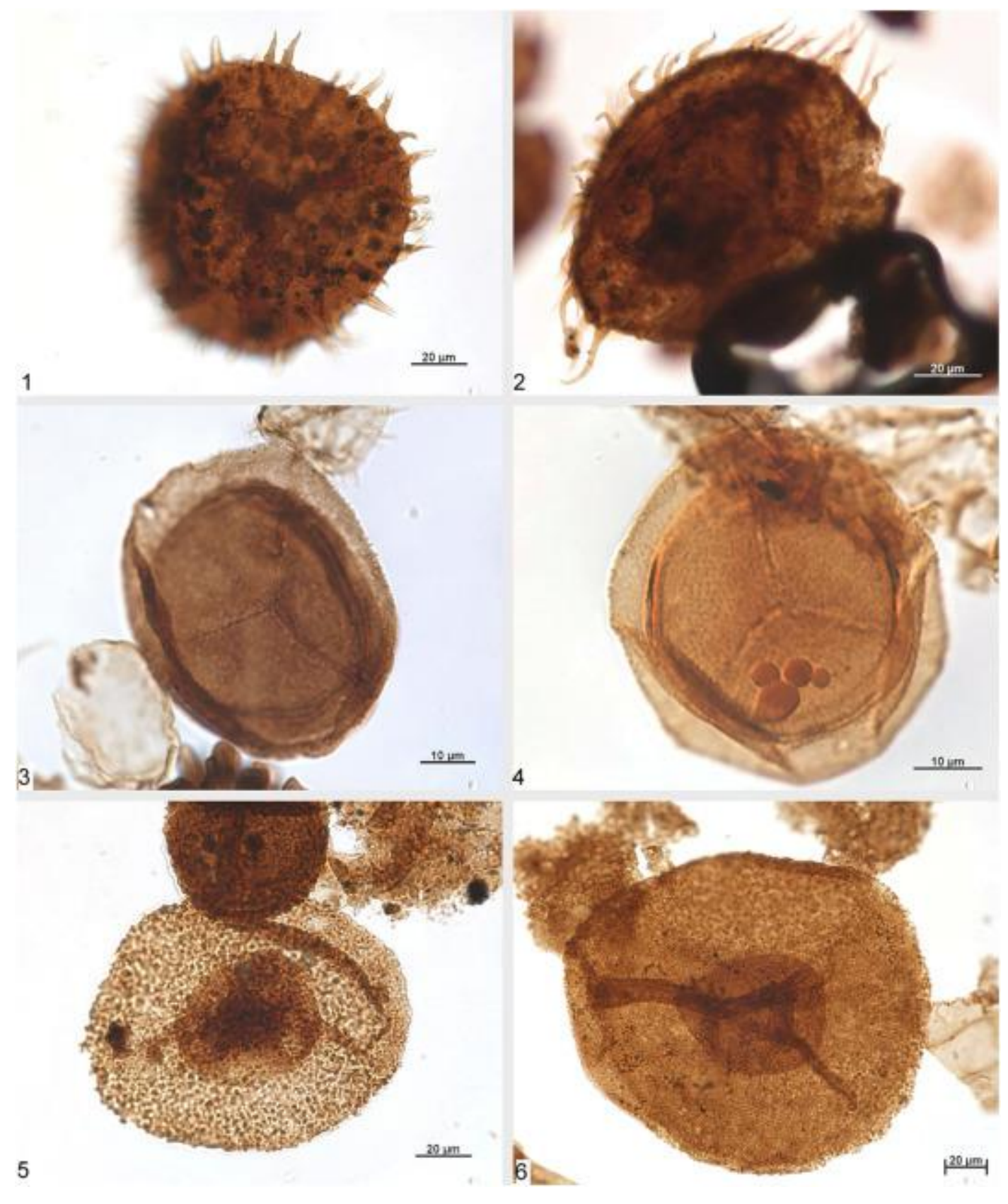


Plate XII.

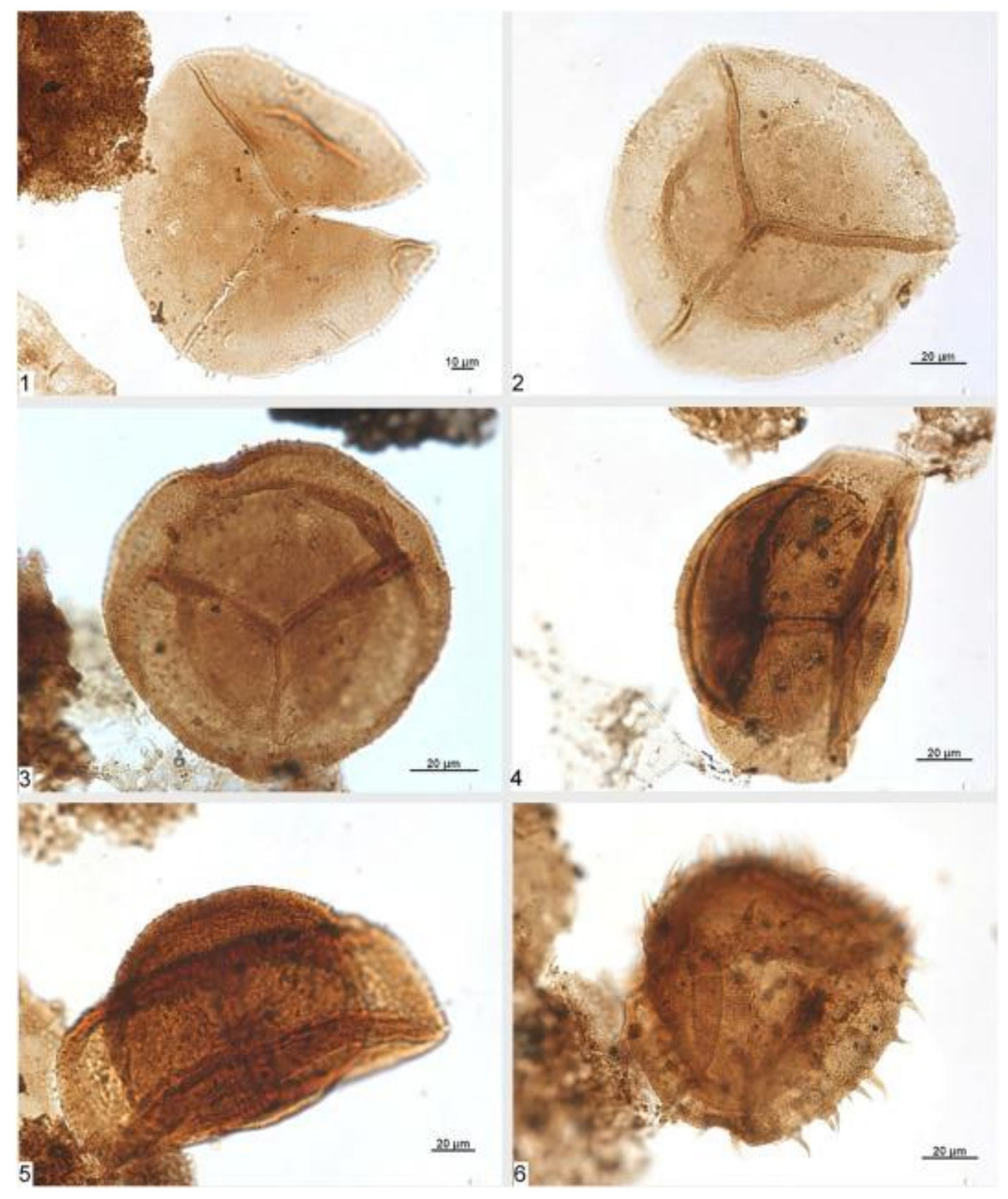


Plate XIII.

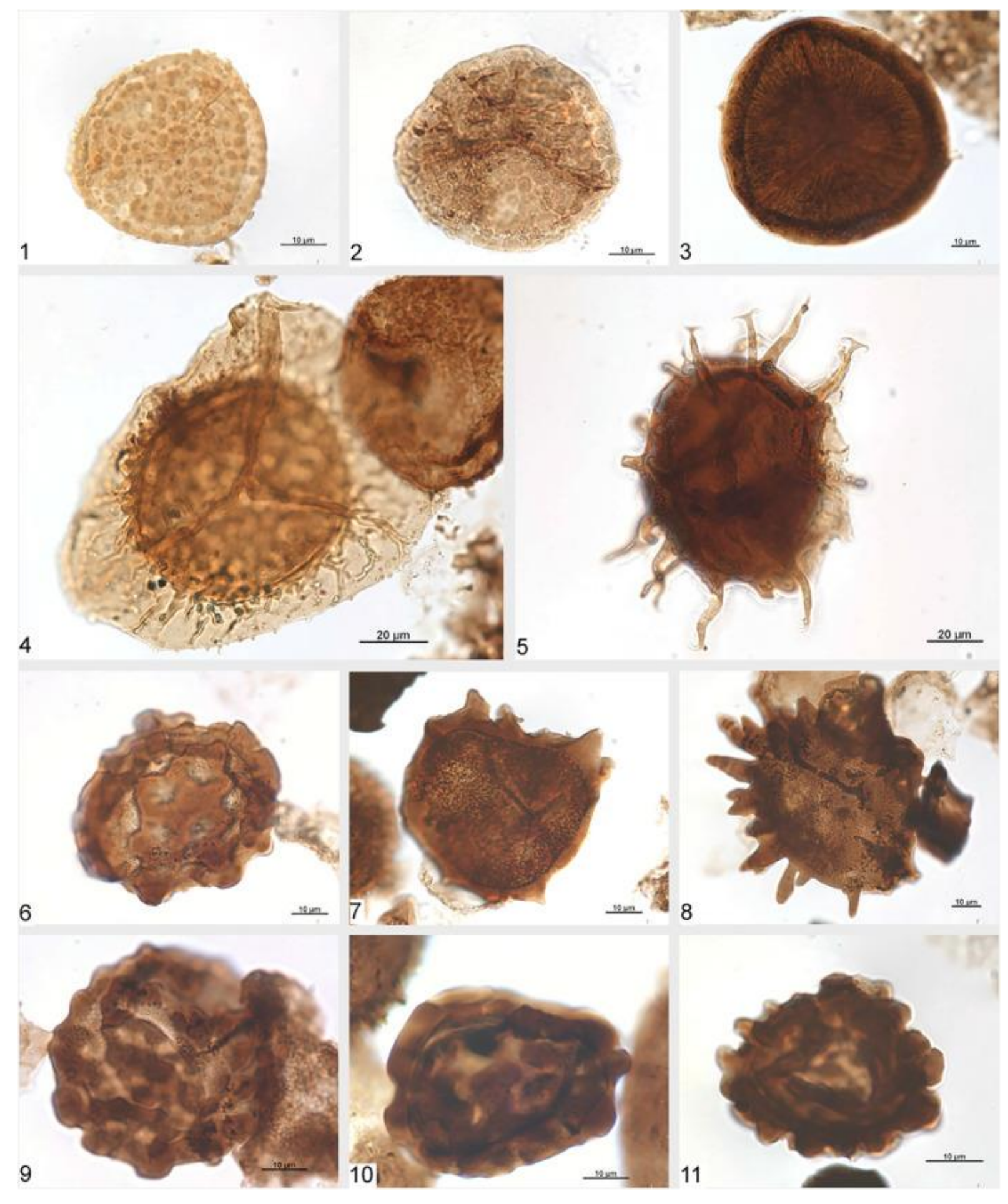


Plate XIV.

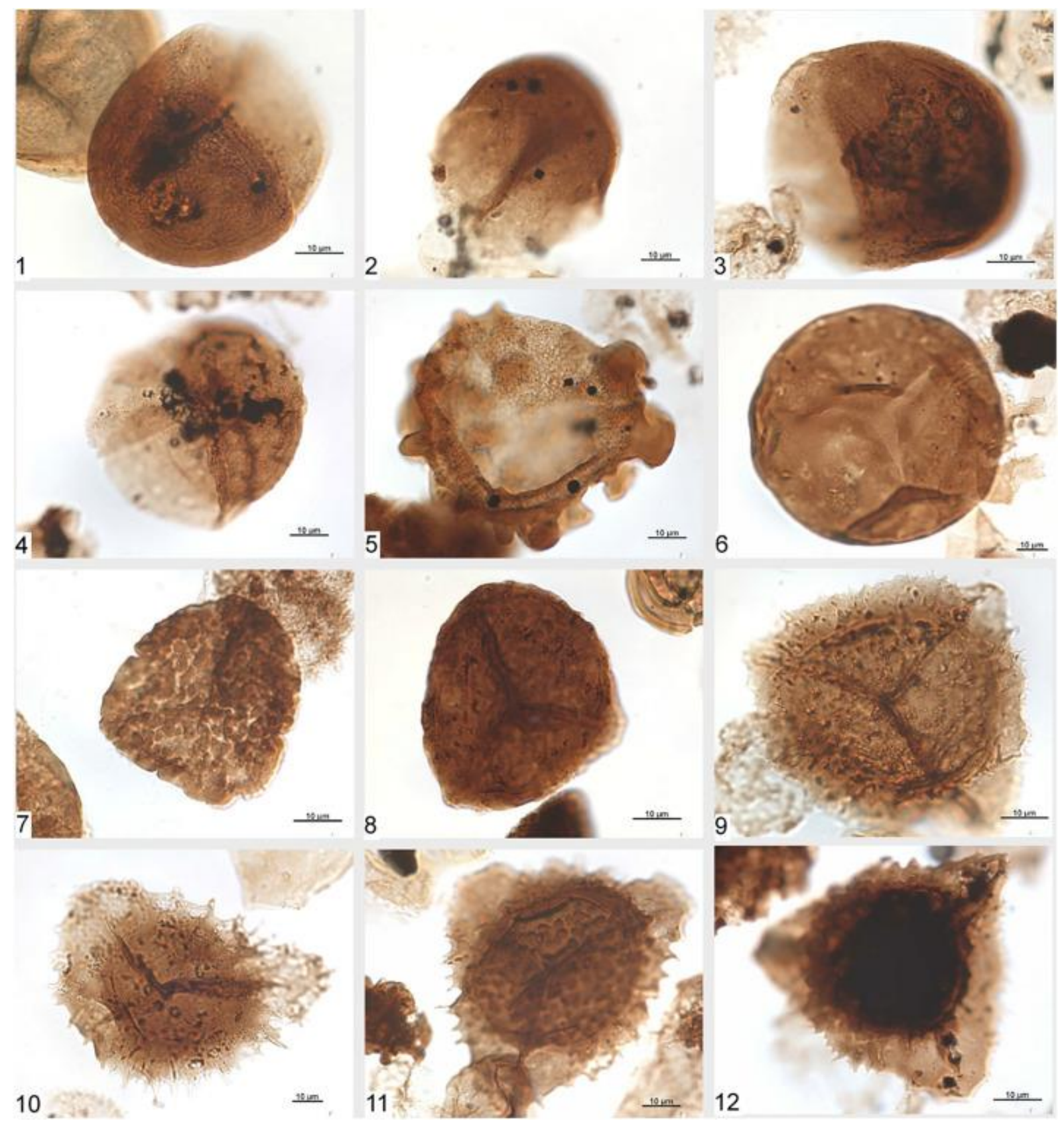




\section{Plate XV.}

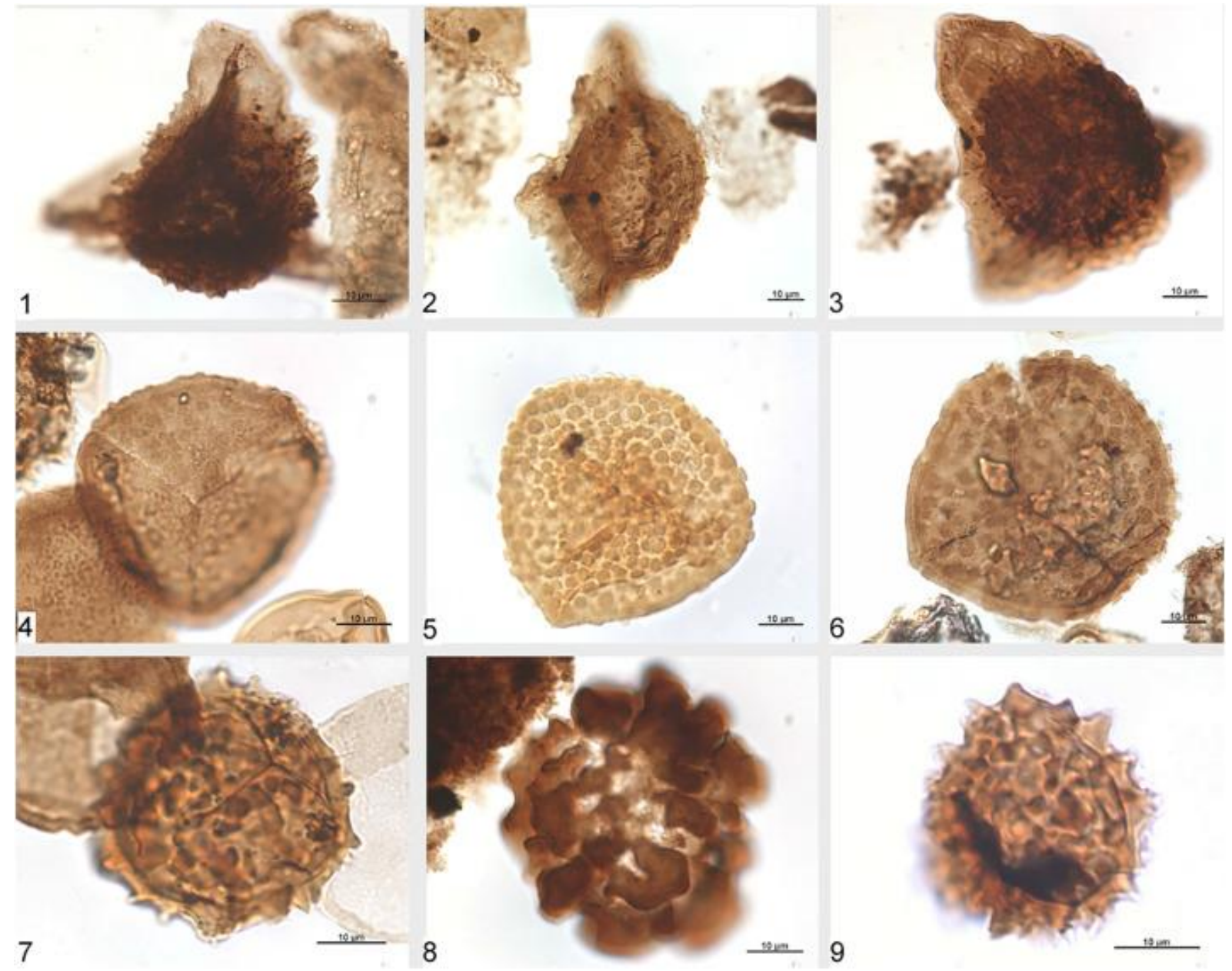

